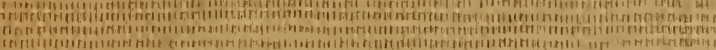

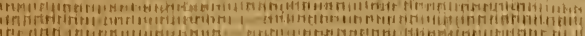

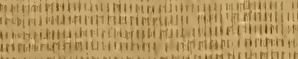

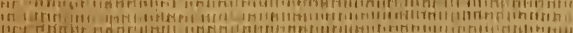

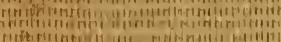

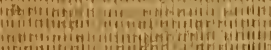

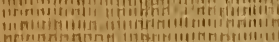





\section{Historic, archived document}

Do not assume content reflects current scientific knowledge, policies, or practices. 
$-$

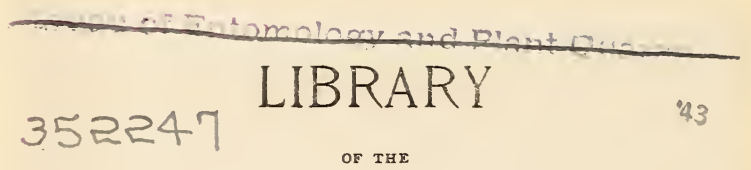

UNITED STATES

DEPARTMENT OF AGRICULTURE

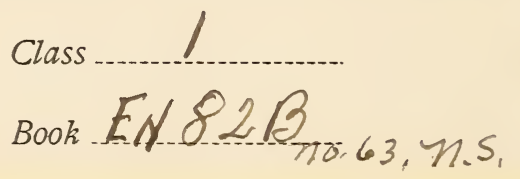








\section{$1 / 127$}

U. S. DEPARTMENT OF' AGRICULTURE, BUREAU OF ENTOMOLOGY-BULLETIN No. 63.

L. O. HOWARD, Entomologist and Chief of Bureau.

Livary, U. S, Department of Agricuicure:
Washingion, D C

\section{PAPERS ON THE COTTON BOLL WEEVIL ANI) RELATED ANID ASSOCLITED INSECTS.}

I. HIBERNATION AND DEVELOPNENT OF THE COTTON BOLL WEEVIL.

By E. DWIGHT SANDERSON, Formerly State Entomologist of Texas.

II. NOTES ON THE BIOLOGY OF CERTAIN WEEVILS RELATED

TO THE COTTON BOLL WEEVIL.

By W. DWIGHT PIERCE, Special Field Agent.

III. AN ANT ENEMY OF THE COTTON BOLL WEEVIL.

By W. E. HINDS, In Charge of Cotton Boll Weevil Laboratory.

IV. A PREDATORY BUG REPORTED AS AN ENEMY OF THE COTTON BOLL WEEVIL.

By A. C. MORGAN, Special Field Agent.

V. NOTES ON THE PEPPER WEEVIL.

By F. C. PRATT, Assistant.

VI. THE STRAWBERRY WEEVIL IN THE SOUTH-CENTRAL STATES IN 1905.

By A. W. MORRILL, Special Field Agent.

VII. THE COTTON STALK-BORER.

By A. C. MORGAN, Special Field Agent.

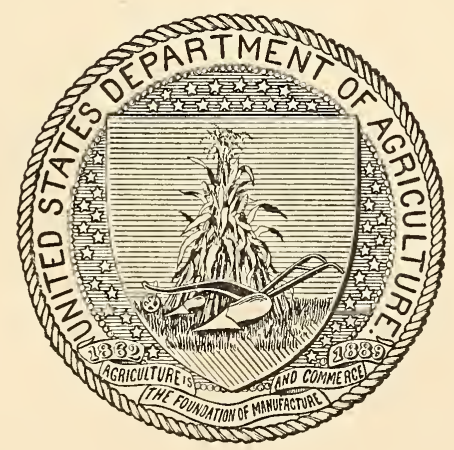

WASHINGTON:

GOVERNMENT PRINTING OFFICE.

1909 . 


\section{BUREAU OF ENTOMOLOGY.}

L. O. Howard, Entomologist and Chief of Bureau.

C. L. Marlatt, Entomologist and Acting Chief in Absence of Chief.

R. S. Cliftox, Executive Assistant.

C. J. Gilliss, Chief Clerk.

F. H. Chittenden, in charge of truck crop and stored product insect investigations.

A. D. HopkIns, in charge of forest insect investigations.

W. D. Hunter, in charge of southern field crop insect investigations.

F. M. WEBSTER, in charge of cereal and forage insect investigations.

A. L. Quaintance, in charge of deciduous fruit insect investigations.

E. F. Phillips, in charge of bee culture.

D. M. Rogers, in charge of gipsy moth field work.

A. W. MorrILL, in charge of white fly investigations.

W. F. Fiske, in charge of gipsy moth laboratory.

R. S. WogLum, in charge of hydrocyanic acid gas investigations.

R. P. Currie, in charge of editorial work.

Mabel Colcord, librarian.

\section{Southern Field Crop Insect Investiga fions.}

IT. D. Hunter, in charge.

W. D. Pierce, R. A. Cushman, C. E. Hood, E. S. Tucker, engaged in cotton boll weevil investigations.

F. C. Bishopp, J. D. Mrtchell, H. P. Woov, engaged in cattle tick life history investigations.

A. C. Morgan, C. R. Jones, engaged in tobacco insect investigations.

D. L. VAN Dine, engaged in sugar-cane and rice insect investigations.

F. C. PRATT, engaged in cactus insect investigations. 


\section{LETTER OF TRANSUITTAL.}

\section{U. S. Department of Agriculture,}

Bureau of Entomology, Washington, D. C., June 10, 1909.

SIR: I have the honor to transmit herewith, for publication as Bulletin No. 63, seven papers dealing with the cotton boll weevil and related and associated insects. These papers, which were issued separately during the early part of the year 1907, are as follows: Hibernation and Development of the Cotton Boll Weevil, by E. Dwight Sanderson; Notes on the Biology of Certain Weevils Related to the Cotton Boll Weevil, by W. Dwight Pierce; An Ant Enemy of the Cotton Boll Weevil, by W. E. Hinds; A Predatory Bug Reported as an Enemy of the Cotton Boll Weevil, by A. C. Morgan; Notes on the Pepper Weevil, by F. C. Pratt; The Strawberry Weevil in the SouthCentral States in 1905, by A. W. Morrill; The Cotton Stalk-Borer, by A. C. Morgan.

Respectfully,

Hon. James Wilson, Secretary of Agriculture.
L. O. Howaro, Chief of Bureau. 



\section{CONTENTS. ${ }^{a}$}

Hibernation and Page.

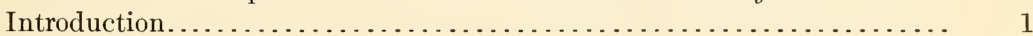

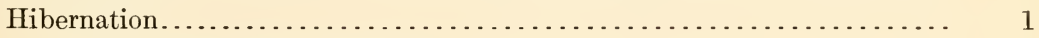

Date of entering hibernation.......................... 1

Number of weevils entering hibernation................... 5

Development of immature stages during normal period of hibernation. 8

Mortality of hibernating weevils......................... 11

Time of greatest mortality during hibernation............... 14

Places of hibernation..................................... 17

Time of emergence from hibernation..................... 19

Prevention of hibernation.............................. 22

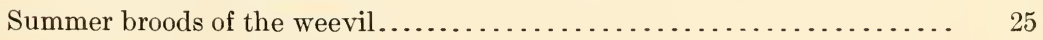

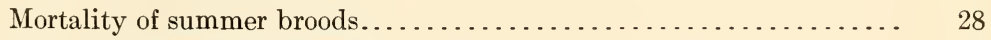

Rate of increase of the weevil........................... 31

Injury to squares in relation to the natural increase of squares...... 33

Notes on the biology of certain weevils related to the cotton boll weevil W. Dwight Pierce. . $\quad 39$

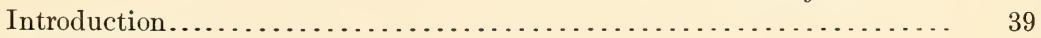

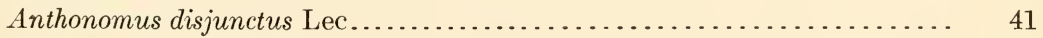

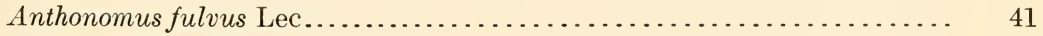

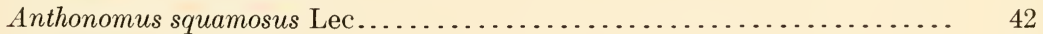

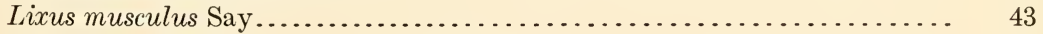

Orthoris crotchii Lec.......................................... 44

An ant enemy of the cotton boll weevil. (Solenopsis geminata Fab. var. xyloni

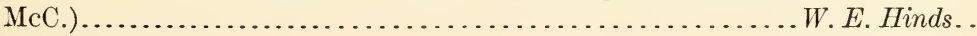

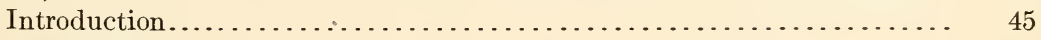

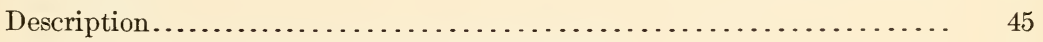

An enemy of the cotton leaf-worm and bollworm................. 46

Its work as an enemy of the cotton boll weevil................ 46

Distribution............................................... 48

A predatory bug reported as an enemy of the cotton boll weevil. (Apiomerus spissipes Say) .................................... C. Morgan. .

Introduction . .

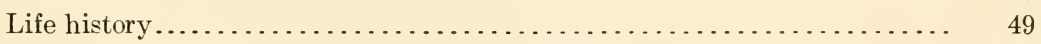

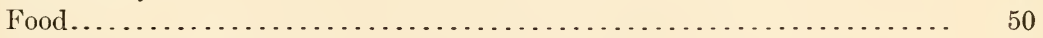

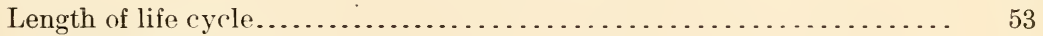

Natural enemies............................................... 54

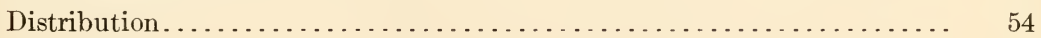

Conclusion........................................... 54

a The seven papers constituting this bulletin were issued in separate form on January 15, February 5, February 5, February 8, February 9, January 22, and February 9 , 1907, respectively. 
Notes on the pepper weevil. (Anthonomus æneotinctus Champ.)..F. C. Pratt. .

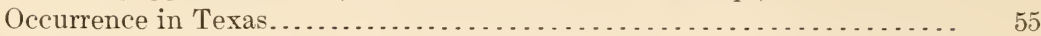

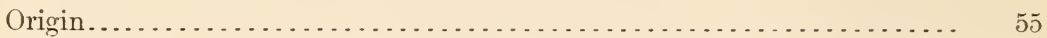

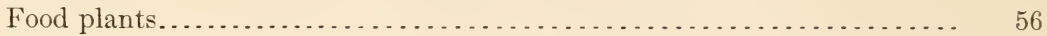

Natural enemies................................................. 56

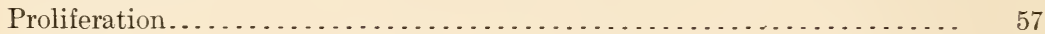

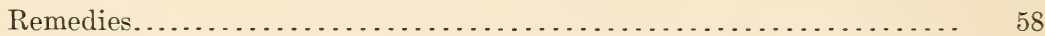

The strawberry weevil in the South-Central States in 1905. (Anthonomus signatus Say) ............................................. 59

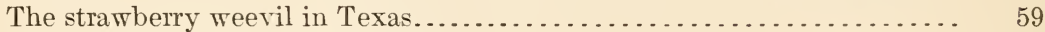

The strawberry weevil in Louisiana........................... 60

The strawberry weevil in Arkansas.............................. 61

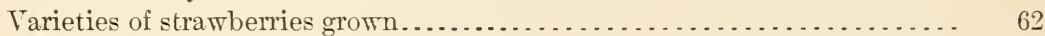

The cotton stalk-borer. (Ataxia crypta Say) ................. C. Jorgan.. 63

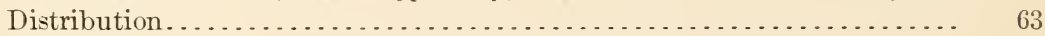

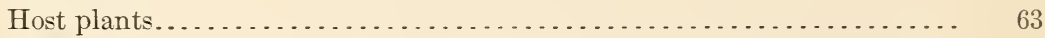

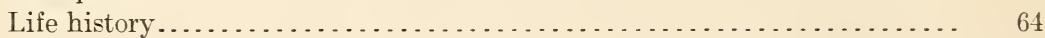

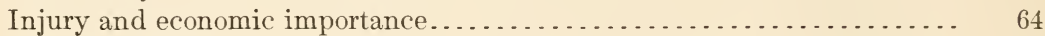

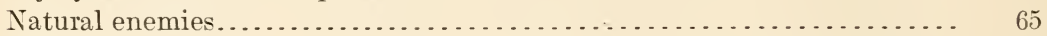

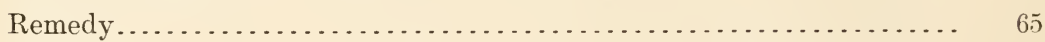

Bibliography................................................ 66 


\section{ILLUSTRATIONS.}

PLATES

Plate I. Work of Lixus musculus and Orthoris crotchii. Fig. 1.-Gall of Lixus Page. musculus and exit hole of adult on stem of Polygonum pennsylvanicum. Fig. 2.-Gall of Lixus musculus and entrance hole (closed) of pyralid caterpillar on stem of Polygonum. Fig. 3.Pod of Mentzelia nuda showing two egg punctures of Orthoris crotchii. Fig. 4.-Pod of Mentzelia opened, showing a cluster of Orthoris crotchii cells, and the cocoons of Tetrastichus. Figs. 5, 6.--Interior of pod of the same, showing several cells of Orthoris crotchii. Fig. 7.-An isolated cell of Orthoris crotchii, showing the manner in which the seeds are eaten ......................

II. Work of the pepper weevil (Anthonomus æneotinctus). Fig. 1.Emergence holes of adult in chilli pepper. Fig. 2.-Full-grown larvæ in situ in chilli pepper. Fig. 3.-Pupæ in cells in chilli pepper. Fig. 4.-Undeveloped bell-pepper pod, showing numerous egg and feeding punctures. Figs. 5, 6.-Malformed bell-pepper

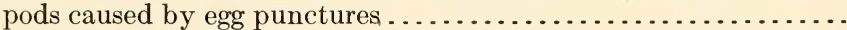

III. The cotton stalk-borer (Ataxia crypta). Fig. 1.-Adult or beetle. Fig. 2.- $a$, Galleries; $b$, work. Fig. 3.-Emergence holes of adults. Fig. 4.-a, Larva in situ; $b$, pupa in situ. Fig. 5.—a, Gallery running into root of plant; $b$, castings behind larva .........

TEXT FIGURES.

Fig. 1. Daily temperatures at College Station, Tex., October 1, 1903, to June

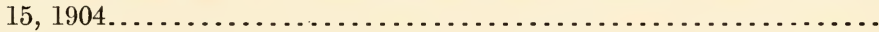

2. Rainfall and temperature records for College Station and Victoria, Tex., in 1903-4, compared with normals. . . . . . . . . . . . . . . .

3. Rainfall and temperature records of College Station and Victoria, Tex., for 1902-3, compared with normals......................

4. Rainfall and temperature records, Hallettsville, Tex., 1899-1901, compared with normals for each year.........................

5. Rainfall and temperature records, Hallettsville, Tex., 1902-1904, compared with normals for each year.........................

6. Comparison of normal temperatures, October 15 to June 15 , for various

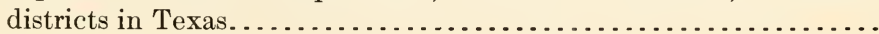

7. An ant enemy of the cotton boll weevil: Cotton squares showing emergence hole of weevil and entrance holes of Solenopsis geminata var.

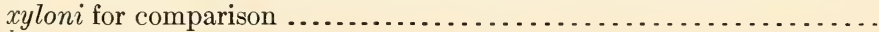

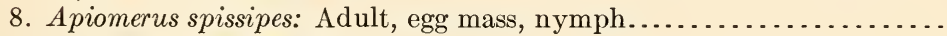

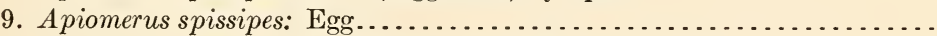

10. The pepper weevil (Anthonomus æneotinctus): Adult............... 



\section{PAPERS ON THE COTTON BOLL IVEEVIL AND RELATED AND ASSOCIATED INSECTS.}

\section{HIBERNATION AND DEVELOPMENT OF THE COTTON BOLL WEEVIL.}

By E. Dwight Sanderson, Formerly State Entomologist of Texas.

\section{INTRODUCTION.}

The most economical method of controlling the boll weevil is to destroy its food supply by burning or grazing the green cotton stalks in the fall before frost occurs, so as to reduce by starvation the numbers which go into hibernation. As it is known that a large proportion of weevils die during hibernation it may be readily understood that a much greater degree of benefit may be derived by destroying the weevils in the fall than by attempting to destroy them in the spring. The time at which the weevils enter hibernation, the numbers which attempt to hibernate, the mortality occurring during the winter and the factor's which influence this mortality, and the time of emergence in the spring are, therefore, matters of practical importance upon which we have made careful observations.

\section{HIBERN ATION.}

DATE OF ENTERING HIBERNATION.

Table I gives a summary of eight lots of weevils which were confined in eages at different dates during October and November, 1903. Altogether some 1,300 weevils were used in these experiments. Beginning with October 7 one cage was started each week until November 17. On November 18 a sharp freeze occurred, and almost immediately thereafter all weevils went into hibernation. It will be seen that in lots 1, 2, and 3 all of the weevils died prior to November 18. During the beginning of these experiments a plentiful supply of squares was furnished the weevils for food, but as they showed an inclination toward hibernating about the third week in October this supply was discontinued. In all cases the weevils which hibernated successfully 
did not begin hibernation until about Norember 17 or 18 . This was also true of other weerils under observation in the laboratorr. The daily notes concerning one or two of the outdoor cages started in October are of interest in this connection. For example, lot 3 comprized 100 weerils put in hibernation cage with food October 16 . The hibernation cages were wooden boxes 2 feet high and 1 foot square, with the sides about one-half open and corered with wire window screening, except the front. which was of glass. In the bottom of each cage was placed plenty of rubbish, consisting of fallen cotton leares, rotten wood. etc. The weerils were thus exposed to the outside temperature, but were largely protected from rain. These cages were placed in rarious situations in a small grove and pasture at the apiary of the Agricultural and Mechanical College, College Station, Tex. The records kept of this lot and of lot 2 are as follows:

October 17,18 , no hibernation, weevils active; October 19, same, quiet in bottom of cage; October 21, sign of hibernation evident, some weevils congregate about dead rubbish on floor of cage; October $22,23,24$, similar conditions, some seem to be hibernating; October 25, a few more in hibernating attitude: October 26, 世reevils are undoubtedly hibernating, shown by dormant attitude under rubbish; October 27, about all hibernating-if they were let out they would not hibernate, as some were let out, and they joined those in the field and commenced feeding; October 29, hot day arouses weevils to activity; October 30, think weevils die at the rate of 1 to 4 per day.

Norember 2, warm weather makes them exceedingly actire; this continues until the 8 th, when cool weather checks their activity; November 15, all weevils dead.

Lot 2.-One hundred weerils placed in cage October 8 and fed with squares; October 9 , weevils lively, flying about in cage; October 10, 11, no signs of hibernation; October 12, less active; October 13, those on rubbish dead or dying; October 14, 110 signs of hibernation; October 15-23, weerils active, no hibernation; October 25, all but $S$ lead, those hibernating under rubbish; October 29, weerils active; October 29-31, November 1, 2, sluggish; November 5, all dead.

TABLE I.-Percentage of mortality of hibernating weevils.

\begin{tabular}{|c|c|c|c|c|c|c|c|c|c|c|c|c|c|c|c|}
\hline \multirow[b]{2}{*}{ Lot. } & \multirow[b]{2}{*}{$\begin{array}{l}\text { Date placed in } \\
\text { cage. }\end{array}$} & \multirow{2}{*}{ 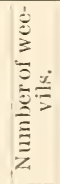 } & \multirow[b]{2}{*}{$\begin{array}{l}\text { Date hi- } \\
\text { bernated. }\end{array}$} & \multicolumn{3}{|c|}{ То Norember $18,1903}$. & \multicolumn{3}{|c|}{$\begin{array}{l}\text { Norember } \\
18-30,1903 \text {. }\end{array}$} & \multicolumn{5}{|c|}{ December, 1903.} & \multirow{2}{*}{ 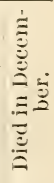 } \\
\hline & & & & $\stackrel{\stackrel{D}{\Xi}}{\Xi}$ & $\stackrel{8}{\Xi}$ & 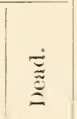 & $\stackrel{\dot{S}}{\Xi}$ & $\stackrel{\Xi}{ٍ}$ & $\stackrel{\check{\Xi}}{\Xi}$ & $\stackrel{\Xi}{\Xi}$ & $\stackrel{3}{Z}$ & 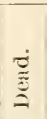 & 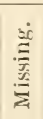 & 产 & \\
\hline 1 & $\begin{array}{c}1903 . \\
\text { October } 7 \text {. }\end{array}$ & 100 & & Nor. 1 & $\begin{array}{c}\mathrm{Per} \\
\mathrm{ct} . \\
\ldots .\end{array}$ & $\begin{array}{c}\mathrm{Per} \\
\mathrm{ct} . \\
100.0\end{array}$ & & $\begin{array}{l}\text { Per } \\
\text { ct. }\end{array}$ & $\begin{array}{l}\text { Per } \\
\text { ct. }\end{array}$ & & $\begin{array}{l}\text { Per } \\
\text { et. }\end{array}$ & $\begin{array}{l}\text { Per } \\
\text { et. }\end{array}$ & & $\begin{array}{l}P e r \\
\text { ct. }\end{array}$ & $\begin{array}{c}P c r \\
c t . \\
\ldots .\end{array}$ \\
\hline "2 & $\begin{array}{l}\text { October } 5 . . \\
\text { October } 16 . .\end{array}$ & 100 & & $\begin{array}{l}\text { Oct. } 24 \\
\text { Oct. } 25 \\
\text { Nor. } 3 \\
\text { Nov. } 5 \\
\text { Oct. } 30 \\
\text { Nor. } 15\end{array}$ & $\begin{array}{l}\cdots \cdots . \\
\cdots \cdots \\
\cdots \cdots \\
\cdots \cdots \\
\cdots \cdots \\
\cdots\end{array}$ & $\begin{array}{c}92.0 \\
99.0 \\
100.0 \\
(b) \\
100.0\end{array}$ & & $\begin{array}{l}\cdots \\
\cdots\end{array}$ & & & $\begin{array}{l}\cdots \\
\cdots\end{array}$ & & & & \\
\hline 4 & October $23 .$. & 100 & Nor. 18 & Yor. 18 & 100.0 & 100.0 & $\cdots$. & $\cdots$ & 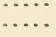 & 14 & 7 & ii & 22 & $7 i 1$ & $\because i$ \\
\hline 5 & Oetober $25 \ldots$ & 300 & ....do... & & ...... & 9.0 & .... & 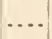 & & $\left\{\begin{array}{r}4 \\
26\end{array}\right.$ & $\begin{array}{l}67 \\
18\end{array}$ & $\begin{array}{l}33 \\
82\end{array}$ & & 82 & 71 \\
\hline$a_{6}$ & $\begin{array}{l}\text { Norember } 1 \ldots . \\
\text { November } 9 . .\end{array}$ & 200 & .... do .... & & 50.0 & $\begin{array}{r}50.0 \\
6.5\end{array}$ & 23 & 50 & 50 & 27 & 14 & 61 & 25 & $61+$ & $11+$ \\
\hline$s$ & November $1 i$. & 200 & ..... do .... & No...... & & & 25 & & 100 & & & & .... & & \\
\hline $\begin{array}{r}5+7 \\
4,5,6\end{array}$ & $\begin{array}{l}\text { Average... } \\
\text { Average... }\end{array}$ & $\begin{array}{l}500 \\
600\end{array}$ & .... do ... & & & $\begin{array}{r}8.0 \\
21.0\end{array}$ & & & & & & & .. & $75+$ & $31+$ \\
\hline
\end{tabular}


TABLE I.-Percentage of mortality of hibernating weevils-Continued.

\begin{tabular}{|c|c|c|c|c|c|c|c|c|c|c|c|c|}
\hline \multirow{2}{*}{ Lot. } & \multirow{2}{*}{$\begin{array}{l}\text { Date placed in } \\
\text { cage. }\end{array}$} & \multirow{2}{*}{ 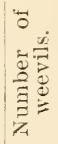 } & \multirow{2}{*}{$\begin{array}{l}\text { Date hi- } \\
\text { bernated. }\end{array}$} & \multicolumn{3}{|c|}{ February, 1904.} & \multicolumn{3}{|c|}{ March, 1904.} & \multirow{2}{*}{ 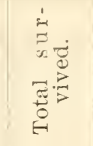 } & \multirow{2}{*}{ 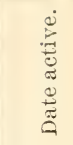 } & \\
\hline & & & & 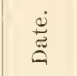 & $\stackrel{0}{\Xi}$ & 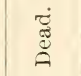 & $\frac{\dot{D}}{\stackrel{\Xi}{\theta}}$ & $\stackrel{0}{\Xi}$ & 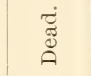 & & & \\
\hline & 1903. & & & & Perct. & Per ct. & & Per ct. & Perct. & Per ct. & \multirow{10}{*}{\multicolumn{2}{|c|}{$\begin{array}{l}\text { Mar. } \\
\text { Mar. }\end{array}$}} \\
\hline$a \frac{1}{2}$ & October $7 . . .$. & $\begin{array}{l}100 \\
100\end{array}$ & & & ( & . & & (...... & (n) & - & & \\
\hline a 3 & Oetober $16 \ldots$ & 100 & . & . & .... & . & . & ( & $\ldots$ & $\ldots$ & & \\
\hline 4 & October $23 . .$. & 100 & Nov. 18 & (b) & & . & . & ......... & . & & & \\
\hline 5 & October $25 \ldots$. & 300 & ....do... & 2 & 7.3 & 91.6 & 22 & 5.6 & 94.4 & 5.6 & & \\
\hline$a 6$. & November $1 .$. & 200 & ....do... & $(b)$ & ...... & ...... & $\ldots$ & $\ldots . .$. & .......... & ........... & & \\
\hline 7 & November 9 . - & 200 & .... do ... & ...... & $\ldots \ldots$ & ...... & 21 & 10.5 & 89.5 & ....... & & \\
\hline 8 & November 17. & 200 & $\ldots$.... do & & $\ldots \ldots$ & $\ldots \ldots$ & 24 & 7.0 & 93.0 & 7.0 & & \\
\hline $5+7$ & Average.. & 500 & .... do ... & & & ....... & $\ldots$. & ......... & ........... & - $\quad 6.2$ & & \\
\hline $4,5,6$ & Average.. & 600 & ... do ... & - & & & & $\ldots$. & $\ldots$ & ............ & & \\
\hline
\end{tabular}

a Furnished with squares for food.

$b$ Accidentally disturbed and discontinued.

It will be seen from these experiments that weevils can not be forced into hibernation before the temperature declines to that point at which they normally hibernate, and that if deprived of food or confined much before that time most of them will die. The first weevils to go into hibernation were those of lot 4, placed in cages on October 23, but these did not actually hibernate until Norember 18. The case of lot 8 , of 200 weevils placed in a cage November 17, in which all died by November 2.5, is difficult to explain. Our notes upon the condition of the weevils in the fields during the same fall show practically the same conditions as those existing in the cages. The very careful record by Mr. A. F. Conradi, made in fields in the neighborhood of the college, is briefly as follows:

September 6, 7, abundant, very few perfect squares, dry weather; September 8, 9, abundant, mating pairs common; September 10, abundant, practically all squares punctured, mating pairs less common; September 11, 12, less numerous, fewer mating pairs, few perfect squares; September 13, less abundant, perfect squares more common, mating pairs scarce; September 14, 15, less abundant, perfect squares more common; September 16-18, fewer weevils, perfect squares more common; September 19, less destructive than at any time since the 10th, perfect squares abundant; September 20-28, similar conditions; September 29, 30, conditions growing worse, more weevils, fewer perfect squares; October 5, numerous, eating vigorously; October 10, exceedingly abundant and destructive, a few dozen perfect squares found with great difficulty, smallest squares often punctured in several places; October 11, abundant, several on plants near field, one in door yard on house, mating common; October 12, 13, abundant, few mating, few perfect squares; October 14, many weevils found clustering about the base of bolls of all sizes just inside of the involucre, no signs of hibernation; October 16, 100 weevils found on 95 plants in thirty minutes; October 18, 19, weevils more sluggish, unusual numbers congregate behind involucres of larger squares; October 20, the size of weevils is exceedingly variable, more so than at other seasons, general depression in activity; October 22, some adults mating, no signs of hibernating; October 23-26, less numerous, no mating pairs, weather cool, beetles seem to be leaving; November 2, abundant in certain localities in the field; on 5 plants they average one to a square, then for a dozen or more none are found; mating common, but little egg laying for several days. 
October 3, weather warm, weevils that had assumed a hibernating attitude lively again, mating pairs and oviposition common; October 4 , much more active, mating pairs and number of eggs increasing, collected 100 weevils from 132 stalks; October 6, conditions similar to middle of September, collected 50 weevils from 46 stalks; October 7, weevils numerous, mating common, more egg punctures, collected 100 weevils from 92 stalks and 67 from 80 stalks; October 9, at apiary, 100 weevils on 98 stalks at east end, 50 on 100 stalks, west end, 48 on 90 stalks at the middle of the field; October 11, 90 weevils on 176 stalks; October 13, average of 1 weevil to 2
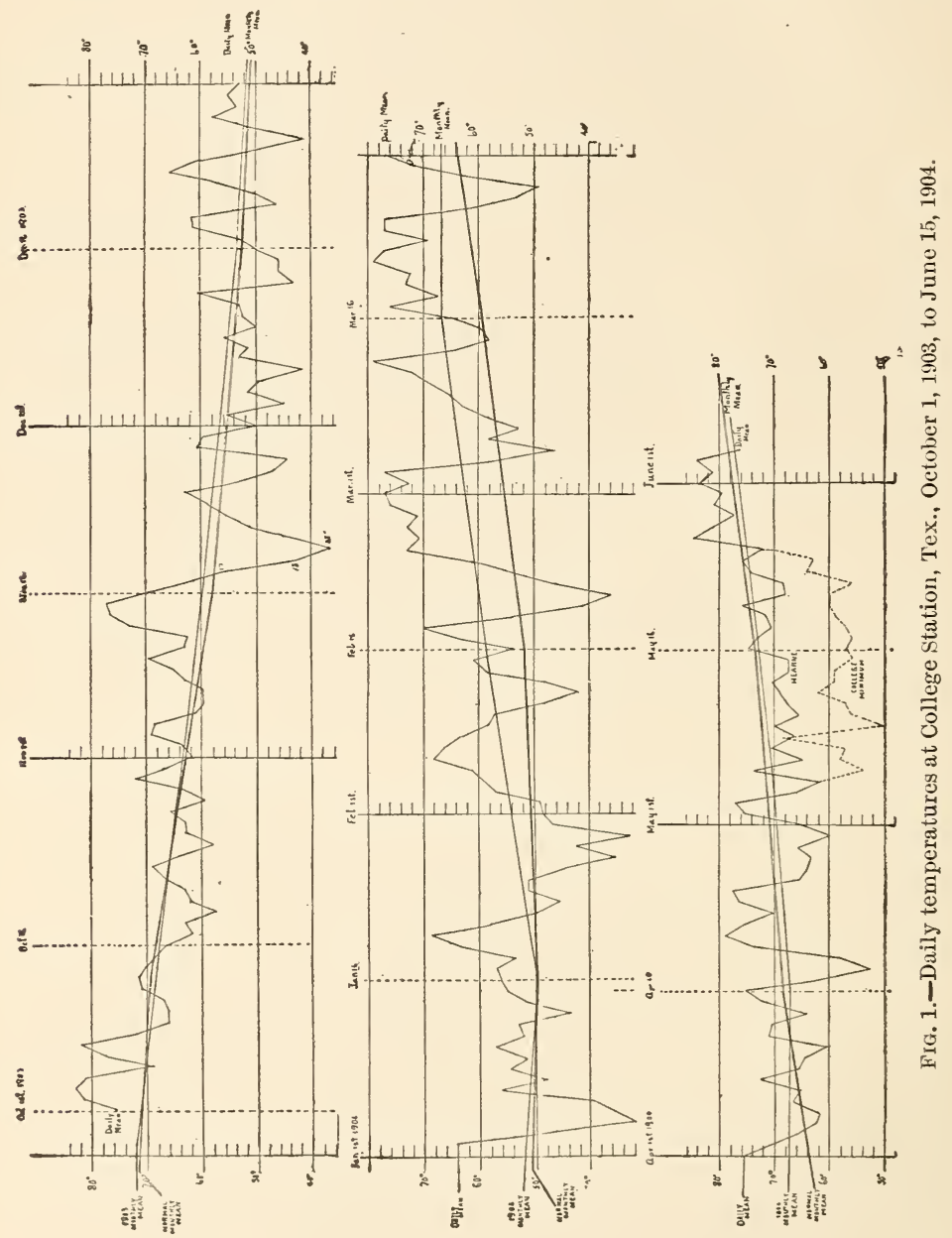

stalks; October 15, 16, weevils active, eggs common; October 17-21, low temperature, with sharp freeze on the night of the 18 th, when the cotton froze and the supply of food was exhausted; October 22 , after the 18 th weevils went into hibernation rapidly, but diminution not markedly noticed until the $22 \mathrm{~d}$, when there was but 1 to 10 stalks.

The weevils were not injured by the freeze of the 18th, as many were found in the field on the $19 \mathrm{th}$. By referring to figure 1 , giving 
the daily temperature, ${ }^{a}$ it will be seen that the activity of the weevils corresponds very closely with the rise and fall in temperature. Hunter and Hinds ${ }^{b}$ state that hibernation will commence as the mean average temperature falls to between $55^{\circ}$ and $60^{\circ} \mathrm{F}$., which our observations of last fall corroborate. They also state that at Victoria hibernation will normally commence about December 1 . By referring to figure 2 it will be seen that the normal temperature at Victoria drops to $60^{\circ}$ at about December 1 and at College Station from November 10 to 15 . At Dallas hibernation would be several days earlier and for northeastern Texas generally about November 1 to 10 . From the observations available, therefore, it would seem safe to assert that hibernation will usually occur when the mean average temperature drops below $60^{\circ} \mathrm{F}$.

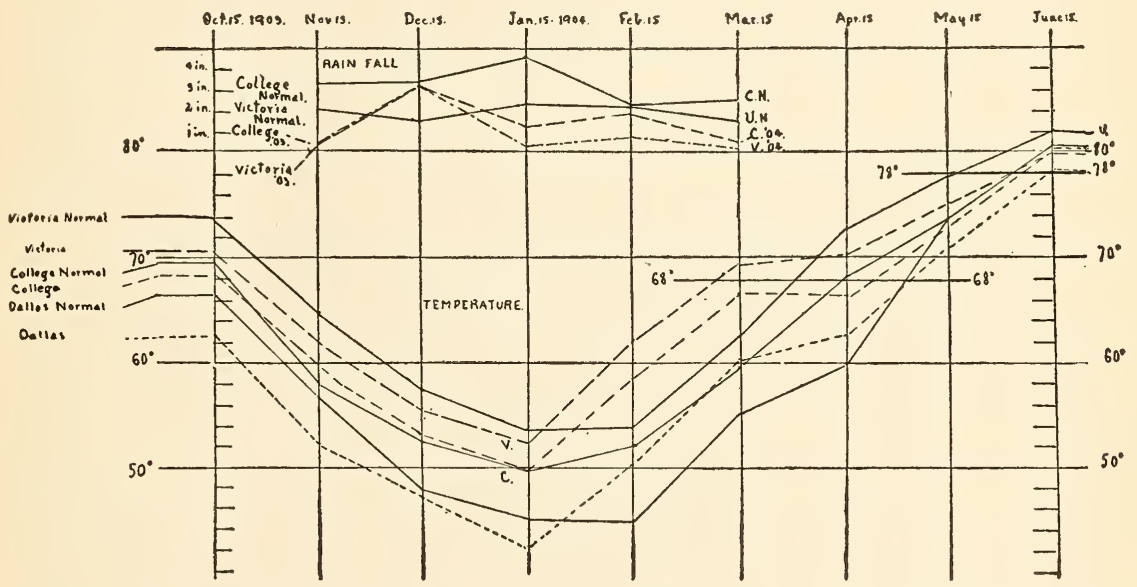

FIG. 2.-Rainfall and temperature records for College Station and Victoria in 1903-4 compared with normals.

\section{NUMBER OF WEEVILS ENTERING HIBERNATION.}

The number of weevils found in an infested field in the fall at about the time hibernation would normally begin is governed largely by the food supply and is influenced also by the temperature and rainfall during September and October.

$a$ Concerning the method of plotting the curves it should be stated that the vertical lines upon which the nodes of the curve occur are marked as being the 15 th of the month. The mean temperature as given by the Weather Bureau is reported at the end of each month. If we should consider the node of the curve as occurring at the end of the month, we would misrepresent the facts, as during the spring and fall the temperature is on a gradual rise or decline. Consequently if the mean monthly temperature is given for the 15 th of the month, the exact temperature for dates between these nodes can be more correctly ascertained from the curve. This applies also to the figures showing rainfall.

$b$ Bul. 45, Div. Ent., U. S. Dept. Agric., p. 81. 
If during september and early October there should be a normal or excessire rainfall and the plants keep growing, there will be plenty of squares upon which the weerils mar breed and multiply until frost occur's. If, on the other hand, during this period the weather should be hot and dry, the plants will stop growing and those infested squares which fall to the ground will be quickly dried up and but a relatively small number of weerils will be produced. This was strikingly shown in observations upon the number of weerils on cotton at the college in the fall of 1903 as compared with the fall of 190t. During September. 1904, there was an arerage of not orer 3 squares to a plant, whereas in September, 1903, there was an arerage of about 40 squares to a plant. At this time during these two seasons there was approximately the same number of weerils in the field: but it can be readily seen that with so few squares in which to breed, in september, 1904. there would be far fewer weevils dereloped after September to go into hibernation.

Mr. Louis Teltschick states that in Lavaca Countr. Tex., at the time he turned cattle in to graze his cotton. October 17.1903 . there were about 2 weerils to a stalk. Concerning this he writes as follows:

I will state in this connection that in my opinion the bulk of the weevils had then left the cotton. I think that during the last three years the majority of weevils began learing the cotton as early as September 1. They were undoubtedly compelled to do this by a scarcity of squares. To be more explicit I gire you the following figures: On August 2s, 1904, I estimated the number of weevils in my field at 12 per stalk. While I made no such estimate in 1902 or 1903, considering the extent of the injury worked by them in those years, I think that their numbers on the same date might safely be put at 6 for 1902 and 9 for 1903 . When I cut the stalks early in October, 1902, I found that there were about $1 \frac{1}{2}$ weerils per stalk, and in October, 1903, when I turned the cattle in, there were about 2 weerils per stalk. You will see that according to these estimates from 75 to 80 per cent of the weevils infesting the fields on August $2 S$ in those years had disappeared by October 15, leaving out of account all weerils hatched between the two dates. Where they went or what became of them I am unable to say: They may have gone to uninfested reyions, or they may have died or gone into hibernation quarters when squares became too scarce to supply all of them.

These observations merely confirm our prerious statement that the number of weevils in the fall is controlled entirely by the food supply.

One of the principal factors in cutting off the food supply of the boll weeril in the fall is the cotton leaf-rorm or so-called "army worm" (Alabemu argillacen Hbn.). Thereas this insect was formerly considered to be the great scourge of the cotton planter. it may now be said to be an almost positive adrantage in territory affected br the boll weevil, as its injury does not ordinarily occur until after the crop has been made, and all further fruiting would be prerented by the boll weevil. As soon as the leaf worms hare stript the cotton of foliage and squares the weerils either die or leare for fields where they may obtain food. This was striking? s shown in an examination of four 
plats at Smith \& Carson's plantation on September 14, 1904. In plats $1-3$, where the leaf worm had stript the plants clean of foliage, but 8 weevils were found to 100 stalks and but 40 per cent of the squares were punctured. On plat 4, immediately adjoining these plats, which had not been so seriously injured by the leaf worm, there were 27 squares to a plant, 148 weevils to 100 stalks, and 70 per cent of the squares were punctured.

Mr. Teltschick has given us some interesting observations upon the leaf worm, as follows:

As far back as I can remember-some twenty-odd years-the people here (Lavaca County) had to fight the leaf worm every year. Arsenic, Paris green, and London purple were used with varying success. At first the worms made their appearance as early as June and frequently hatched in such numbers as to enable them to sweep a field clean in less than 48 hours. Gradually, however, this wave of worms subsided; that is to say, they made their appearance later and later in the season, and became fewer in numbers, until finally when the boll weevil made its first appearance, their coming was no longer viewed with alarm. On the contrary they were often welcomed by the farmers, inasmuch as they cleared away the thick foliage of the cotton plant, thus often saving a considerable number of the bolls at the bottom, which would otherwise have rotted for the want of light and air.

At the time of the weevils coming here (seven or eight years ago) the worms were no longer regarded as a menace to the cotton crop; they made their first appearance then either late in August or early in September. They kept this up practically until in 1902 and 1903 they failed to come at all. This year (1904) they reappeared early in September and completely stript cotton of its foliage. The second destructive brood of worms is just now (October 2, 1904) hatched, and there is every reason to believe that they will keep the stalks bare until frost as they did in former years. It will have to be admitted that during 1902-3, when cotton grew and formed squares undisturbed up to the first frost, which occurred in December of both years, an opportunity was given the weevil to go into hibemating quarters later in the season and in greater numbers than would have been the case had the further growth of cotton been prevented either by man's or nature's means.

Thus the leaf worm accomplishes practically the same result as is obtained by grazing stalks with cattle and may be considered a most valuable ally.

The number of weevils which go into hibernation may of course be decreased by the thoro grazing of the cotton with cattle before frost, or by cutting, plowing out, and burning the stalks. It is safe to say that by a thoro fall clearing of the ground the number of weevils entering hibernation can be decreased at least 75 per cent. Weevils in all stages are thus immediately destroyed, and if the land is cleared of cotton a month before the normal hibernation period the weevils then escaping are almost certain to starve, as has been shown in Table I, before it becomes cold enough for them to hibernate.

Under normal conditions, as noted in Table III, column 3, the number of weevils to a stalk at the time of hibernation will vary from 1 for every 2 stalks to 2 for each stalk in badly infested fields, the number depending, as before stated, entirely on the food supply and 
weather conditions. There seems to be no reason to believe that any difference will be found in the number of weerils in infested fields in northern Texas as compared with southern Texas except as it may be controlled by these factors, for after the third brood becomes matured the number of weerils depends entirely upon these conditions.

\section{DEVELOPMENT OF IMMATURE STAGES DURING NORMAL PERIOD OF} HIBERTATION.

In southern Texas during an open dry winter larræ, pupæ, and adult weerils may frequently be found in the injured bolls hanging upon the cotton stalks. In feeding upon the bolls the larre frequently eat a hole thru the septum between two locks and form a small carity just under the inner surface of the lock. These feeding cavities become lined by the dried and hardened excrement, so that when a lock is broken to pieces the weevil cells may be separated out and have quite the appearance of seeds. It is within such cells that the immature stages pass the winter in the bolls. Occasionally, howerer, the larræe eat into the seed, so that immature stages may be found actually within the seeds. This is undoubtedly not the usual habit and there seems to be practically no danger of disseminating weerils actually secreted inside of the seeds. We hare been unable to make a personal examination of these conditions, but on February 20, 1903, Mr. W. P. Allgood, of Derine, Medina County, Tex., wrote us sending some cotton bolls and seed, in which we found $t$ weerils alive, 1 dead, 1 newly transformed, 1 in a seed, and also 2 seeds which seemed to have been eaten out by weevil larræ, but which contained only larra which may hare been parasitic upon the weeril. The $t$ live weerils were kept in a tube in our laboratory until about April 1, when they died, owing to the unsuitable conditions.

Sereral of the infested seeds were evidently entered before the shell was fully hardened and the normal development of the seed prerented, whereas in other cases the weerils were in seeds fully dereloped. It seems quite reasonable that the larre should bore into the seeds during the early winter, for as the cotton matures the seeds would be more succulent. Howerer, it seems exceedingly improbable that weerils could be disseminated by being carried in the seed, for they occur within the seed only on unopened bolls which hang upon the plant, and rery rarely would cotton in which weerils had entered the seed erer be ginned.

Eally in March of the same year Mr. Allgood sent the writer quite a quantity of bolls, which were examined March 12 with the following result:: Out of 200 bolls 165 contained no weerils in any stage, alive or dead. but of these. 20 per cent had been noticeably injured by weerils. Forty, or 20 per cent, contained weerils alive or dead in some stage. In these to bolls there were to live and 11 dead pupe, 
30 live and 40 dead adults, and 5 dead larvæ. Many of these weevils had just transforined from pupæ and were still soft and light brown. Some transformed after being received. But one live larva was found in all the material examined. Mr. Allgood wrote the writer that these bolls had been collected from stalks in a neighbor's field in which there were 7,000 plants to the acre, that each plant held from 12 to 15 bolls, and that the bolls sent in were picked at random from the field. Upon this basis, disregarding the live pupæ but counting the 30 weevils which were found alive as having survived the winter, there would have been 10,500 weevils per acre in the spring. If but one-third of these survived there would have been 3,500 per acre, or more than have erer been recorded in any field observations. If, as seems quite possible, but one-fifth survived, there would have been 2,100 per acre, which is approximately the number which survived in Lavaca County under the favorable weather conditions of the winter of 1903-4. Mr. Allgood wrote that cattle were then grazing in these fields, but it is doubtful if the cattle would have eaten many of the dry hardened bolls. In another lot of 48 bolls and forms sent by Mr. Allgood at the same time, we found 18 uninhabited large bolls, 15 forms, and 15 small bolls. These contained 17 live weevils, 4 live pupæ, 4 dead pupæ, and 2 dead larvæ, or one live weevil to every 3 bolls or forms. These weevils were confined in a wooden box in the laboratory and were still alive April 10, but later died, as no food could be supplied them at that time under temperature conditions such that they would normally have emerged. Doubtless they would all have emerged early in April at Devine. The temperature at Pearsall, the nearest weather station to Devine, during the winter was as follows: December, 1902 , mean $54^{\circ}$, lowest $30^{\circ}$; January, 1903 , mean $51.8^{\circ}$, highest $80^{\circ}$, lowest $29^{\circ}$; February, 1903 , mean $52.8^{\circ}$, highest $77^{\circ}$, lowest $23^{\circ}$; March, 1903 , mean $60.6^{\circ}$, highest $82^{\circ}$, lowest $38^{\circ}$.

It will be seen that there were but few days during the winter in which the temperature was below freezing. The total mean temperature for these four months at Pearsall was but $63^{\circ}$ less than the total normal mean for southwestern Texas during this time, and the rainfall at Pearsall was but 6.34 inches greater than the normal for southwestern Texas, no normal records for Pearsall being given. The total rainfall of these months is normally but 7.51 inches for southern Texas, so that the rainfall was nearly double the normal and the winter would appear to have been exceedingly unfavorable for the hibernation of weevils in their usual places of shelter. However, weevils which developed in the unopened bolls were almost entirely protected from the excessive rainfall, and the temperature being normal they would probably survive, while those weevils which went into hibernation in all usual places in the fall would doubtless have suffered an excessive mortality due to the unusual rainfall. 
Immature stages and adult weerils are often found in early winter in the unopened bolls hanging on the stalks thruout the infested regions. Te received live adult weevils in bolls from Hamilton, Hamilton County, in December, 1903, and they have been observed here and elsewhere, but we have no record of weerils haring been found alive in these situations in early spring in central Texas, and it is exceedingly doubtful if many of them would survire the winter except in southern Texas.

TABLE II.-Condition of immature stages of weevils after date of normal hibernation.

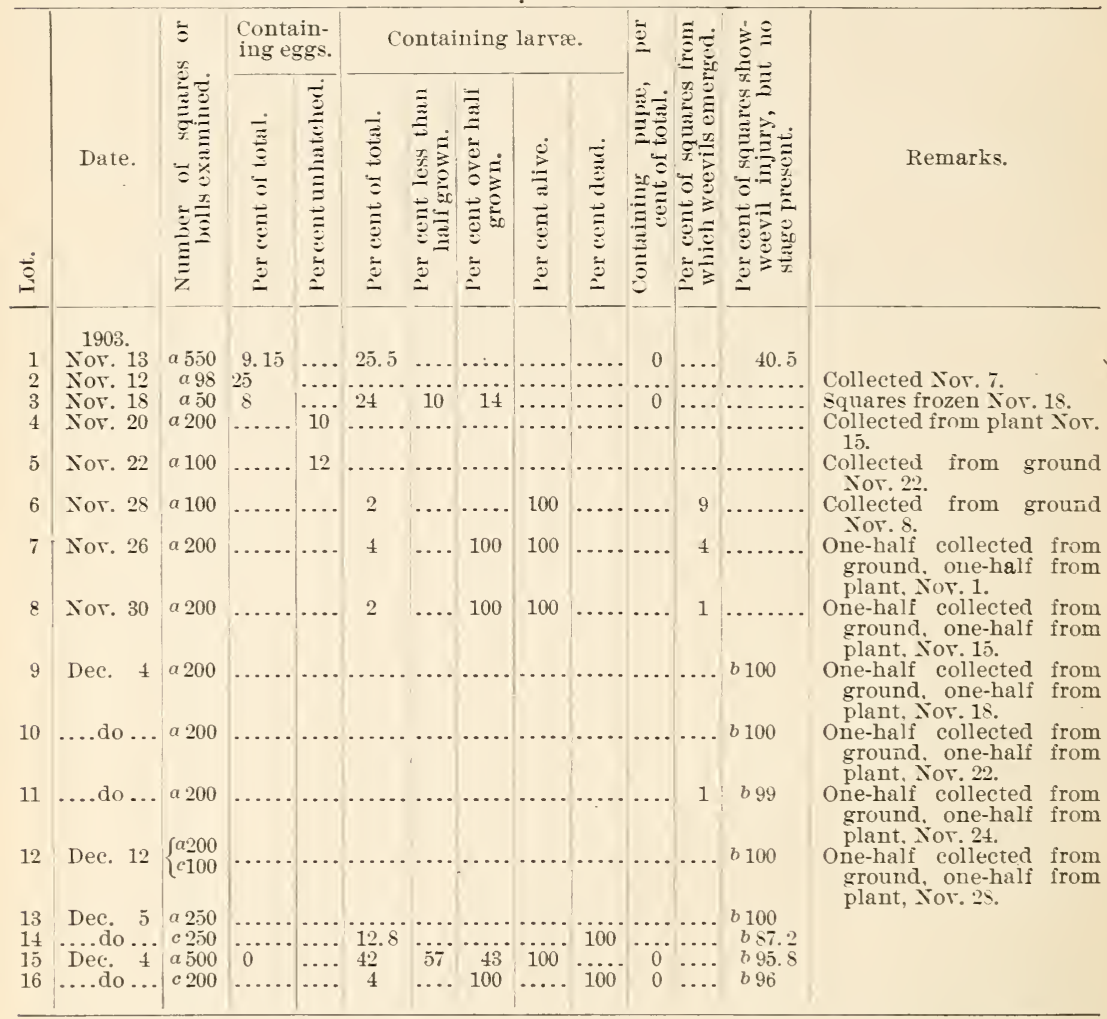

$a$ Squares.

$b$ Squares with no stage of weevil in them. Percentage injured unknown, but probably 40 per cent as in lot 1 .

$c$ Bolls.

In Norember and December, 1903, Mr. Conradi made careful obserrations at College Station upon the condition of the immature stages after the freeze of Norember 1s. The results of these observations are shown in Table II. It will be noticed that no pupæ or adults were found in over 3,600 squares and bolls examined, showing that egg laying had temporarily ceased during some period before Norember 1 . The most probable explanation of this remarkable absence of 
pupæ and adults in the presence of eggs and larvæ is that an outbreak of the cotton leaf-worm (Alabama argillacea Hbn.) had completely defoliated the plants during the latter part of September, preventing entirely the formation of squares, and thus stopping abruptly for a short time the multiplication of the weevils in squares. Subsequently squares were formed, and when these became large enough the reproduction of weevils was resumed after about November 1 , so that most of the larva found were over half grown. In lots 4 and 5, when examined November 20 and 22, from 10 to 12 per cent of the eggs were still unhatched. It seems probable that at this time some of the eggs, but no large percentage, failed to hatch. Most of the larvæ died during the first stage and but few lived to be over half grown. On November 12 , in lot 2,25 eggs were found in 98 squares, which were collected November 7, showing that the egg period had been doubled. Mr. Conradi notes in this connection that the life-history period was first noticed to be decidedly lengthened after November 9, eggs laid November 10 requiring 5 days to hatch. From 24 eggs hatched between November 24 and 28, 15 larva died within a day after hatching, 7 by the time they were half grown, and but 2 developed into weevils, which emerged December 4 .

On December 12 an occasional larva was found in the field and several were brought into the laboratory, where 3 transformed to pupæ January 7, but then died. They would undoubtedly have failed to pupate in the field.

\section{MORTALITY OF HIBERNATING WEEVILS.}

The mortality of weevils during hibernation is shown in Tables I and III. Table I gives the mortality of weevils confined in cages at different dates from October 7 to November 17, as previously described. In but two lots did weevils survive the winter. In these lots ( 5 and 7 ), of 500 weevils an average of 6.2 per cent survived the winter and were active between March 22 and March 24. On March 21, however, 10.5 per cent were alive, and it was noted that these weevils had been active since March 18, so that practically 7.5 per cent of the two lots survived the winter under the supposedly favorable conditions furnished them in the hibernation cages. 
TABLE III.-Percentage of ueevils surriving hibernation in fields.

\begin{tabular}{|c|c|c|c|c|c|c|c|c|c|c|c|c|}
\hline \multirow{3}{*}{ Year. } & \multirow{3}{*}{ Locality. } & \multirow{3}{*}{ 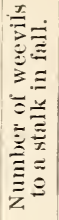 } & \multicolumn{4}{|c|}{$\begin{array}{c}\text { Weather: December- } \\
\text { March. }\end{array}$} & \multirow{3}{*}{$\begin{array}{l}\text { Date first } \\
\text { emerged. }\end{array}$} & \multirow{3}{*}{$\begin{array}{c}\text { Dates } \\
\text { counted, } \\
\text { inclusire. }\end{array}$} & \multirow{3}{*}{ 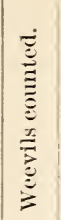 } & \multirow{3}{*}{$\begin{array}{l}\text { Area } \\
\text { counted. }\end{array}$} & \multirow{3}{*}{ 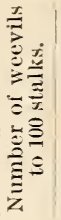 } & \multirow{3}{*}{ 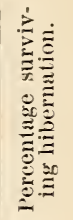 } \\
\hline & & & \multicolumn{2}{|c|}{ Rainfall. } & \multicolumn{2}{|c|}{$\begin{array}{l}\text { Tempera- } \\
\text { ture. }\end{array}$} & & & & & & \\
\hline & & & $\begin{array}{l}\text { Win- } \\
\text { ter. }\end{array}$ & $\begin{array}{l}\text { Nor- } \\
\text { mal. }\end{array}$ & $\begin{array}{l}\text { Win- } \\
\text { ter. }\end{array}$ & $\begin{array}{l}\text { Yor- } \\
\text { mal. }\end{array}$ & & & & & & \\
\hline $1900-1$ & Vien & & $b+5.51$ & 8. 32 & +2.7 & 55.8 & Mar. 10 & & & 10 acre & & \\
\hline $\begin{array}{l}1902-3 \\
1903-4\end{array}$ & & & $\begin{array}{l}+6.86 \\
-5.08\end{array}$ & 8.32 & +.5 & 55.8 & 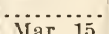 & & & & & - \\
\hline 1900 & Booth & (1) & $e+5.71$ & 14.47 & $\begin{array}{l}+1.1 \\
-5.0\end{array}$ & $\begin{array}{l}55.8 \\
55.5\end{array}$ & & May 22-31. & $\begin{array}{l}2,400 \\
2,000\end{array}$ & & $\begin{array}{l}31.0 \\
13.0\end{array}$ & $\begin{array}{r}\text { d } 30 \\
13\end{array}$ \\
\hline 19 & $\mathrm{Hu}$ & & $f-9$ & 7.02 & -.8 & 54.7 & & May $30 . .$. & 6 & 140 stalk & 4. 0 & \\
\hline 1902 & Wellborn . & $\ldots . .$. & $g-8$. & 13.40 & -9.1 & 55.7 & & May 22-29. & 397 & & 2.5 & 2.5 \\
\hline 1903 & $\ldots . . d$ & $h 2.00$ & $g+2$ & 13.40 & -11.6 & 55.7 & May 8 & $\begin{array}{c}\text { June } 26- \\
\text { July } 17 .\end{array}$ & 1 & 2,125 stalks & .04 & \\
\hline $1903-1$ & .....do... & 1.00 & $g-2.45$ & 13.40 & +2.1 & 55.7 & Apr. 17 & May 20- & 26 & 1.600 stalks. & 1.6 & 1.6 \\
\hline 1903 & $\begin{array}{c}\text { College Sta- } \\
\text { tion } i\end{array}$ & & -1.38 & 12.72 & -3.5 & 53.6 & May 15 & June $18 \ldots$ & 5 & 940 stalks. & .5 & \\
\hline 1903 & & & -1.38 & 12.72 & -3.5 & 53.6 & & $\ldots$. do $\ldots$. & 2 & 40 stalks... & 5.0 & 5.0 \\
\hline & & & & 12.72 & & 153.6 & Mar. 29 & May 19- & 49 & 2,930 stalks. & 1. 66 & \\
\hline 1904 & .....do. do. ${ } .$. & 1.00 & -6.12 & 12.72 & +14.1 & 53.6 & Apr. 1 & May $22-$ & 20 & 1,810 stalks. & 1.0 & 1.0 \\
\hline 1904 & Rosprim.n.. & (?) & -6.12 & 12.72 & +14.1 & 53.6 & Apr. $S$ & June $7 . .$. & 10 & 1,000 stalks. & 1.0 & \\
\hline
\end{tabular}

a Observations by Louis Teltschick.

$b$ Record for Hallettsville.

c Three-fourths-acre trap rows.

$d$ Estimate of sereral fields, May 17.

$e$ Records of Houston, as far as given.

$f$ Record for New Braunfels.

$g$ Records for Brenham. $h$ August 17,2 weerils per 100 stalks. $i$ In sorghum in 1902 .

$k$ Cotton, 1902, a (rossroad br barn.

$l$ Cotton not destroyed in fall of 1903 .

$m$ Cotton destroyed in fall of 1903.

$n$ In corn in 1903.

In the field we have never found the percentage surviving at the college to approach this number, except in one instance. As shown in Table III, in the spring of 1903 cotton was planted near the college barn, where it had been grown the prerious year and left standing. The weerils had the most farorable conditions possible for hibernating around the barn. They appeared so numerously on the cotton in the following spring that on June 18 there were 5 hibernated weevils to erery 100 stalks. More weevils were found in this cotton thruout the year than in anr other locality. If it be fair to assume that about one weeril to a stalk occurred in this field at the time of hibernation in the fall of 1902 , then about 5 per cent survired. It is quite possible that there were more than this number in the fall, and the percentage surviring would therefore be somewhat less. Elsewhere, in the neighborhood of the college, not orer 2 per cent hare ever been found to survive the winter in the field, tho several fields within a distance of 4 miles have been carefully observed.

In the Brazos bottom, on Smith \& Carson's plantation, Professor Mally (report, ${ }^{a}$ p. 16) records picking 397 weevils from 2 acres May $22-29,1902$, or 2.5 weevils to 100 stalks, which would give not orer 2.5 per cent surviving hibernation. In 1903 but 1 weeril was found to 2.125 stalks, or $0.0 \pm$ to 100 stalks, which would give a percentage of hibernation of not over $0.0 t$ and probably 0.08 , as there were 2 weevils 
to a stalk the previous fall. During the present year (1904) but 1.6 per cent survived hibernation on the plots counted. This figure is open to slight error, as upon this plantation there were possibly 20 acres of cotton about a mile away, which were planted much earlier than was most of the plantation. This early cotton was infested at the rate of 20 weevils to 100 stalks on May 31. It is evident that the weevils which hibernated on the plantation as a whole had concentrated on this early planting, but if the total number of weevils upon this early cotton had been distributed over the whole acreage there would have been not over $2 \frac{1}{2}$ weevils per 100 stalks or 2.5 per cent surviving hibernation at the most. 'Two per cent would probably be very nearly correct. At Victoria, Hunter and Hinds have shown that approximately 15 per

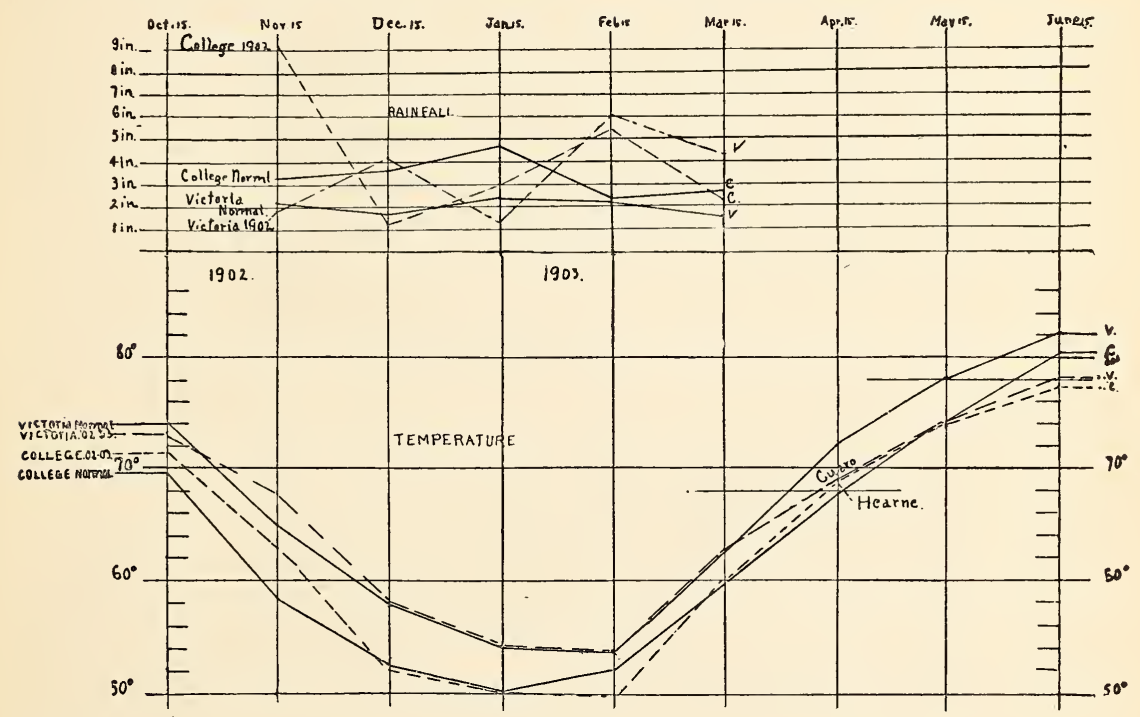

FIG. 3.-Rainfall and temperature records of College Station and Victoria, Tex., for 1902-3, compared with normals.

cent of late-developed weevils survived the winter of 1902-3 in hibernation cages. 'The very careful records made by Mr. Teltschick by hand-picking the weevils during the spring (see p. 59 of that report) shows that this very closely approximates the number of weevils normally surviving under field conditions in Lavaca County, but that during the last winter (1903-4) fully 30 per cent of the weevils, or twice as many as usual, hibernated suceessfully. In 1900 Professor Mally's records (l. c., p. 32) show that $\mathrm{Mr}$. Kramer picked 2,000 weevils at Booth, Fort Bend County, or 13 to 100 stalks, which would give at ieast 13 per cent surviving the winter, in a latitude practically the same as that of Vienna. It will be seen, therefore, that whereas 15 per. cent may be considered an average of the number surviving 
hibernation in southern Texas, normally only about 2 per cent, and never over 5 per cent, survive under field conditions at College Station, and about $2 \frac{1}{2}$ per cent in the Brazos bottom at Wellborn. In other words, only about one-fifth as many weevils survive the winter here as do in southern Texas. Whether a corresponding difference will be found in the mortality between central Texas and northern Texas remains to be determined. This will depend on the weather conditions discust below, but it seems doubtful that there will be so great a difference.

\section{IIME OF GREATEST MORTALITY DURING HIBERNATION.}

In Table $\mathrm{I}$ it may be seen that in lots 4,5 , and 6 , including 600 weevils, there was a mortality of at least 51 per cent during the month of December, and that in lot 5 there was a mortality of 9.6 per cent during January and but 2.8 per cent during the remainder of the year. Referring to figure 2 it may be seen that at College Station in the winter of $1903-t$ the rainfall was greatest in December, while during the balance of the winter it was below normal. 'The maximum in December approached the normal, whereas usually the maximum for winter occurs in January. The temperature was very close to normal thru January, but considerably above normal during the remainder of the winter.

In general, an excessive rainfall seems to be a most important factor in increasing the mortality of the weeril. The temperature does not usually depart sufficiently from the normal to be an important factor, except that when occurring with a deficient rainfall an excess of temperature appears to be decidedly beneficial to hibernation. By referring to figures $t$ and 5 , showing the normal rainfall and temperature for Hallettsville, Tex., and the monthly mean temperature and rainfall during the winters of 1899-1900, 1900-1901, 1902-3, and 1903-4, it may be seen that in 190C-1901 there was a decided deficiency in rainfall and a slight excess in temperature, whereas in 1902-3 there was an abnormally large rainfall and a nearly normal temperature. In 1901 and 1904 the weevils survived in unusally large numbers, while in 1903 the number hibernating successfully was considerably less than normal. The same general conclusions are shown when the rainfall and temperature records as given for College and Brenham in Table III are compared with the percentage of weerils surviving at College and in the Brazos bottom below Wellborn. The rainfall and temperature records are shown diagrammatically in figures 2 and 3, giving also the normal rainfall aná departure from normal for College Station and Victoria in 1902-3 and 1903-4.

If it be true that the rainfall is the most important climatic factor in the mortality of the hibernating weevils, it is interesting to compare the rainfall of different sections of the State as given by the 


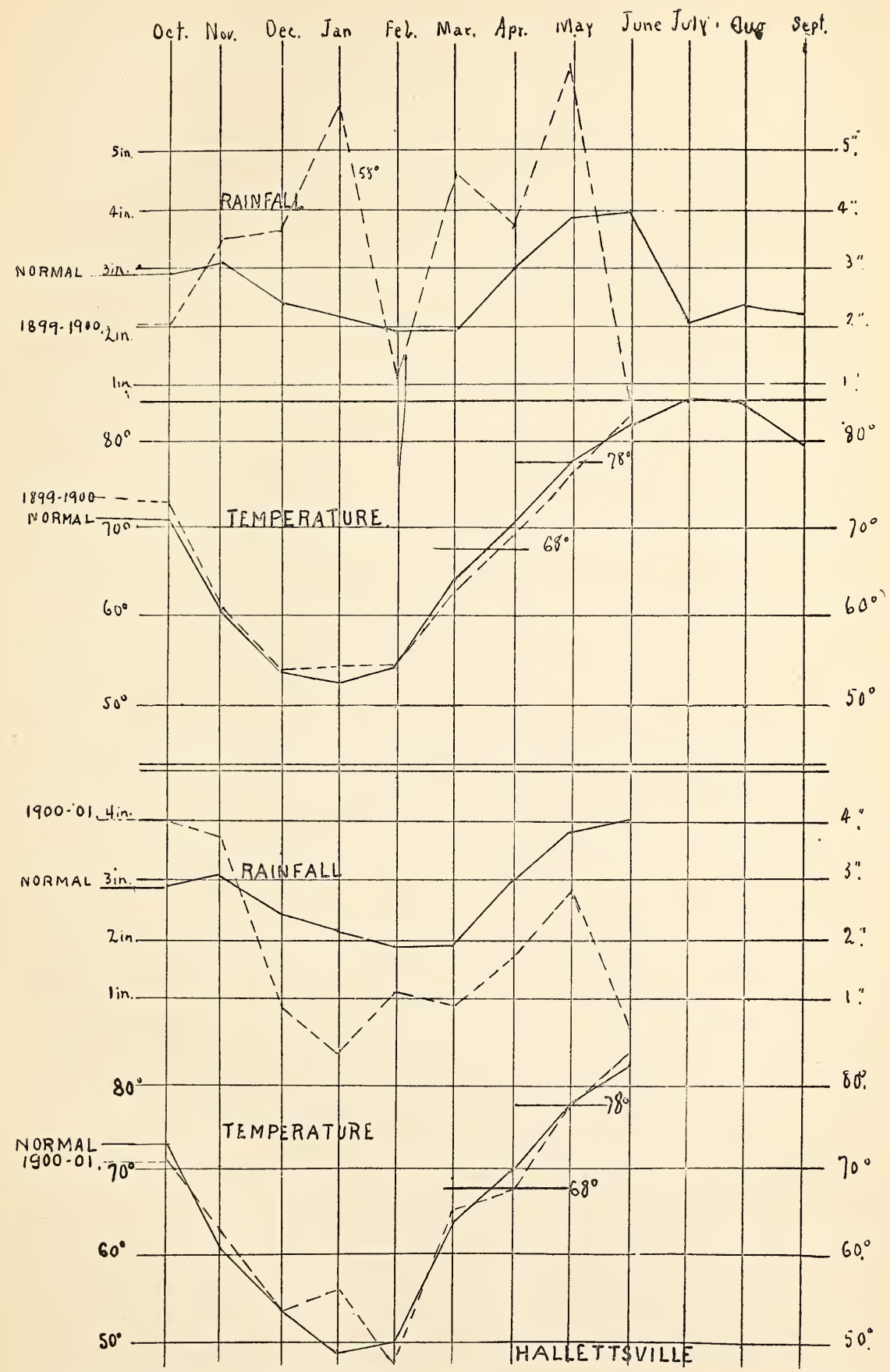

FIG. 4.-Rainfall and temperature records, Hallettsville, Tex., 1899-1901, compared with normals for each year. 


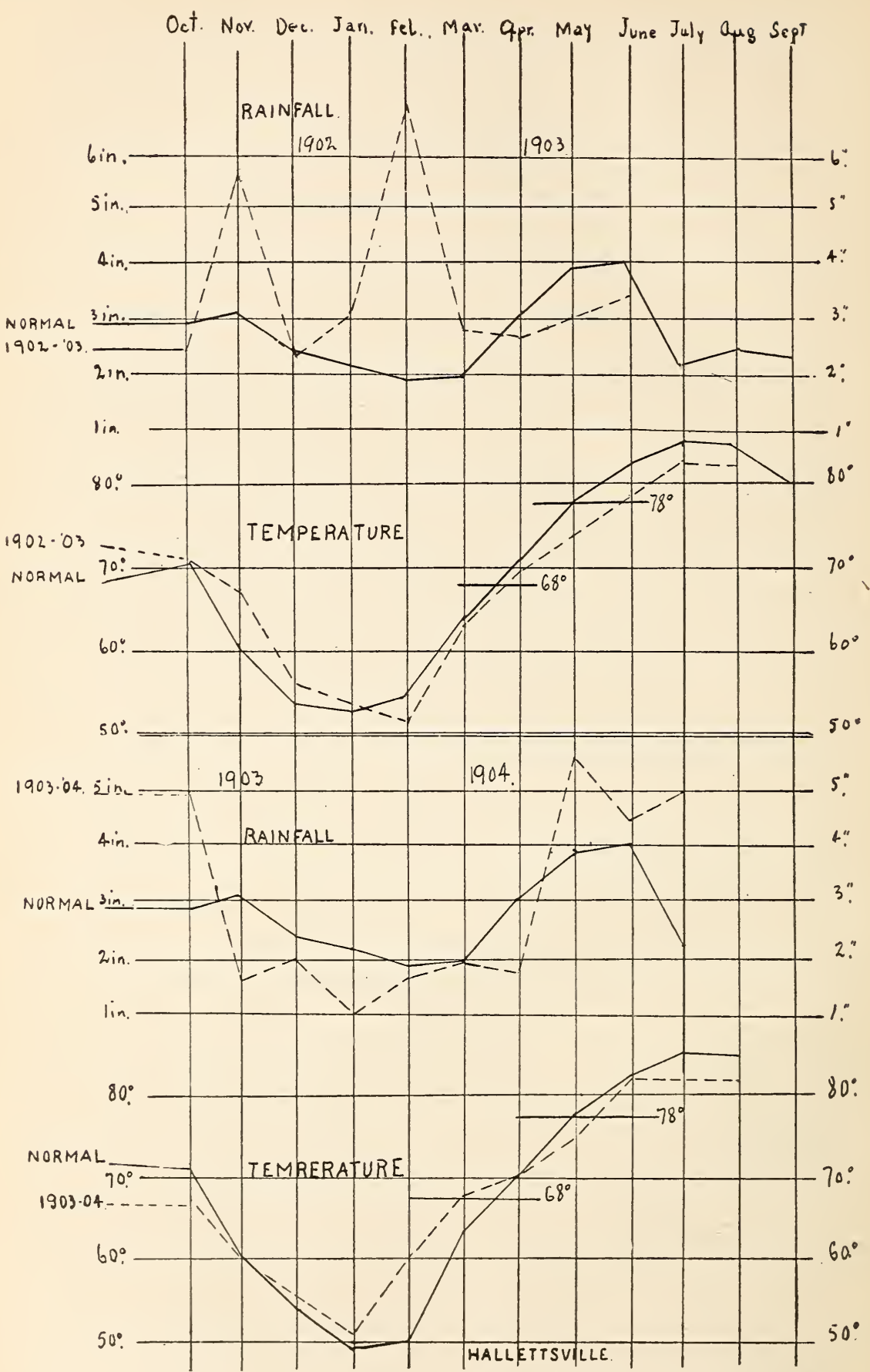

FIG, 5.-Rainfall and temperature records, Hallettsville, Tex., 1902-1904, compared with normals for each year. 
Texas section of the U. S. Weather Bureau. The normal total rainfall during the winter months of December to March for southwestern Texas is 6.46 inches, for the coast country 8.26 inches, and for central Texas 9.83 inches, while the total normal effective winter temperature $^{a}$ during December to March, inclusive, is, for southwestern Texas $1,631.4^{\circ} \mathrm{F}$., for the coast country $1,190.6^{\circ} \mathrm{F}$., for eastern Texas $1,483.1^{\circ} \mathrm{F}$., for northeastern Texas $934.9^{\circ} \mathrm{F}$., and for central Texas $1,294.3^{\circ} \mathrm{F}$. The average effective temperature for the eastern and southwestern countries is therefore from $200^{\circ}$ to $300^{\circ}$ higher than that of central Texas for this period and from $450^{\circ}$ to $700^{\circ} \mathrm{F}$. higher than that of the coast and northeastern Texas. If we consider the more critical period of December to February, inclusive, the southwestern and eastern countries have $300^{\circ}$ to $200^{\circ} \mathrm{F}$. more effective temperature than central Texas and from $600^{\circ}$ to $500^{\circ} \mathrm{F}$. more than northeastern Texas. It would therefore seem that both the temperature and rainfall are far more favorable to the successful hibernation of the weevil in southwestern Texas than in central, coast, or northeastern Texas, and that the conditions as to temperature and rainfall in the coast country during the critical period are very similar. In northeastern Texas, however, as the weevils do not emerge from hibernation until considerably later in the spring, the larger rainfall occurring during April may have some effect on them.

As before mentioned, floods during the period of hibernation seem to have a marked effect upon the mortality of the weevil, as there were notably fewer weevils thruout the Brazos bottom in this section in the spring following the flood of February, 1903.

\section{PLACES OF HIBERNATION.}

Considerable time has been spent in attempting to find the places in which the weevils spend the winter, but the results have been rather unsatisfactory. This has also been the experience of many observing practical farmers. Numerous cotton fields were examined in the neighborhood of the college during January and February, 1903, and tho Mr. Newell and the writer made diligent search in all conceivable places over a considerable acreage, embracing an area of 2 miles, examining cornstalks, grass, bark, fence posts, gins, etc., we found but 1 live boll weevil during the winter and this one was under a small pile of dried manure. On November 29, 1903, Mr. A. F. Conradi found 2 weevils in a pile of old cotton brush in our experimental field, 3 under the bark of a log near the field, and 2 in the cotton field under a bunch of dead cotton leaves. On December 15 a thoro examination

$a$ Total normal effective temperature is reckoned for each month by subtracting $43^{\circ}$ F. (the point at which animal activity is supposed to begin) from the normal mean temperature for that month, multiplying the difference by the number of days in that month, and adding together the four products thus obtained. 
was made of logs, leaf rubbish, etc., in a ravine adjoining our cotton field, but no weevils were found. On December 28 a similarly futile search was made along Carters Creek, in which neighborhood a good deal of cotton had been grown. On January 5, 1904, a 30-acre cotton field was thoroly examined, but no weevils were found. Corn stubble standing near a very badly infested field was also examined without finding any weevils. Our information regarding the hibernating places of the weevil is therefore more of a deduction based upon observations of the places in which they appear first in the spring than a conclusion from actual observations. The observations by $\mathrm{Mr}$. Conradi in the early winter probably indicate the normal places for hibernation-that is, under dead leaves, in old cotton brush, and under loose bark. In the hibernation cages, where the weevils were furnished an abundance of rubbish, it was found that many of them which were hibernating successfully had crawled into the cavities made by borers in dead wood and in similar positions where they were well protected. It has been often noticed that in a wooded country the weevils appear first in spring along the borders of fields next to the woods and gradually work inward from the edges, so that it seems probable that in a wooded country most of them hibernate in woodland. Around outbuildings and barns also are found favorable places, as there is always more or less rubbish and protection in such situations. In 1903 more than five times as many weevils were found in a piece of cotton near the college barn, where cotton had been grown the previous year, than were found in any other locality in that neighborhood. It is also noticeable that weevils are always more numerous near gins than at a distance from them. Undoubtedly, where much rubbish and grass are present and where the soil remains loose and is not packed by rains, large numbers of the weevils winter in the cotton fields. The fact that in 1903 an exceedingly small number of weevils survived on Sinith \& Carson's plantation on the Brazos River must have been due to their having hibernated in the field, large numbers having been killed off by the excessive rains and doubtless more by the flood of February, 1903, which covered the fields to a depth of sereral inches over a large part of the plantation. It was quite noticeable that few weevils were found on Brazos bottom plantations in this section in 1903. In all probability the flood would have had but little effect later in the season after the weevils had emerged.

It is noticeable that weevils are much more abundant where cotton is planted in fields where sorghum stubble has been allowed to remain all winter adjoining a last year's cotton field. Thus, in the spring of 1904 , the first weevils found on Smith \& Carson's plantation were on a cut of cotton along the Brazos River which had been in sorghum and surrounded by cotton in 1902 and where several large sorghum stacks stood thru the winter. Tho planted early and kept well cultivated, 
so little cotton was made on this piece that it was not worth picking, while cotton planted at the same time and cultivated in the same manner on other parts of the plantation made a good yield.

Professor Mally (l. c., p. 57) has given the observations of Mr. Teltschick upon finding weevils hibernating in the crevices of the soil around the cotton stalks and roots, at a depth of 3 inches. On March 7, 1901, a raw, windy day, upon 35 stalks, he found 7 live and 2 dead weevils from 1 to 3 inches below the surface. In September, 1902, he stated that he had again found weevils in a similar situation during the previous spring, but not as many of them as in 1901. Mr. Teltschick recently writes as follows:

I found but few weevils in crevices around stalks during the last two winters, partly because there were no crevices (frequent rains filling them up as soon as formed) and partly because freezes were severe enough to keep cotton from coming out during any part of the last two winters; whereas in 1900 we had neither rain enough to fill up crevices nor frost enough to keep cotton from budding out at intervals at the base of the stalk, which latter fact accounts, no doubt, for the relatively large number of weevils found within the crevices.

\section{TTME OF EMERGENCE FROM HIBERNATION.}

Hunter and Hinds ${ }^{a}$ state that the first weevils emerge when the mean average temperature has been for some time above $60^{\circ}$. Our observations at the college upon the earliest emergence from hibernation are as follows: In 1903 the first weevil was found on May 15 at the college after carefully searching about 100 feet of unchopped row. Repeated examinations during the next two weeks showed but a very small number of weevils. On May 8 a weevil was found in the Brazos bottom after hunting about 20 minutes, and after May 5 planters in the bottom occasionally reported finding weevils. In 1904, on cotton planted March 17, the first weevils were found on March 29. On April 17 and 18 only an occasional weevil could be found at College Station or in the Brazos bottom after a considerable search. In 1903 Mr. Teltschick wrote me on March 1 from Lavaca County as follows:

Up to a severe freeze of two weeks ago (February 16-17) I could at any time find some--not many-in my neighbors' fields apparently feeding on buds or small leaves at the base of the stalk, which had never been entirely frozen.

However, he did not find many on his own cotton until April, when he picked some from trap rows which were planted on March 13. In 1904 he noticed the first weevils about the middle of March, but, as in previous years in other localities in southern Texas, we have records of their feeding on shoots from stumpage cotton much earlier than this. In general, it seems that when the normal mean temperature 
passes $68 \mathrm{~F}$. the first weerils commence to emerge from hibernation, and this conclusion is confirmed by all of our observations.

It will be seen from the temperature curres in figure 2 that at Victoria the normal mean temperature usually reaches $65^{\circ}$ about April 1 and at College rbout April 15. Figure 2 shows that in 1903 the mean avcrane temperature racbe 168 about one week later at Victoria. In 1904 (fig. 2) the mean temperiture reached $68^{\circ}$ about March 10 at Victoria and the first weevils were found about the middle of March, which is also true of Lavaca County. while at College Station $65^{\circ}$ was reached a week later than usual, but the trmperature was abore $66^{\circ}$ for the month preceding April 15. If the mean rise in temperature from February 15 to May 15 be plotted, the line would reach $68^{\circ}$ about April 5, which very closely approximates the clate of the first

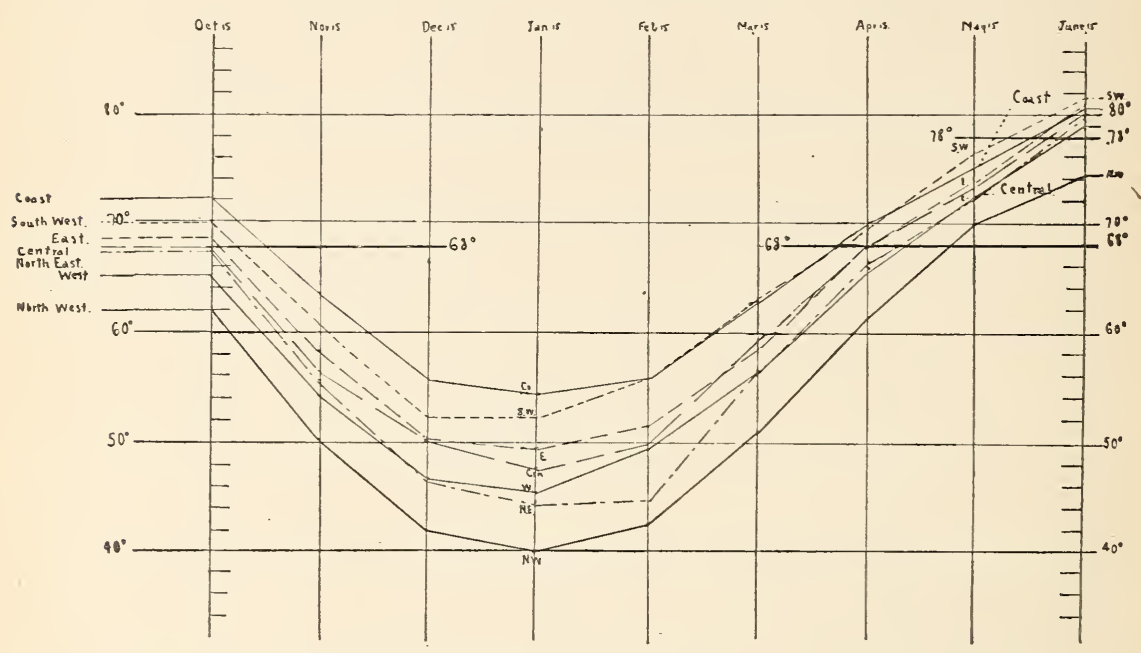

FIG, 6.-Comparison of normal temperatures, October 15 to June 15, for various districts in Texas.

appearance of the weevils at College Station for that year. From all the data available, therefore, it seems very safe to assert that when the temperature reaches $68^{\circ}$ or has been above $65^{\circ}$ for several weeks the first weevils will emerge. By consulting figure 6 this time may be seen for any section of the State. The curve shows that weevils would normally emerge from hibernation about 10 days earlier in the southwestern and coast count rics than in central and northeastern Texas. and about 20 days earlier than in northwestern or western Texas.

The greatest number of weevils emerge considerably later and usually about the time cotton commences to square. The time of the principal mergence and the beginning of general oriposition by the hibernating brood is practically the same. A few belated weerils appear after this time. as is shown by the field records of Mr. Teltschick for 1903 and 1904 . For if the bulk of the weerils emerges at the 
time the cotton commences to square freely and frequent counts be made, the number will be found to decrease for a few days, and there is then a sudden rise due to the maturing of the first brood early in June, and it is practically impossible to determine in the field whether any hibernated weevils subsequently emerge. However, in 1904, it is certain that no weevils emerged later than June 29, for at that date practically no weevils could be found in the field, tho the bulk of the hibernating weevils appeared from June 5 to June 10. Consequently this year (1904) certainly no weevils emerged later than 22 days after the maximum number.

It has previously been shown by Professor Mally (1. (., p. 16) and by Hunter and Hinds, and noted above, that the weevils emerge gradually over a period of from 4 to 6 weeks, normally more nearly the latter time. This range covers practically the same length of time as from planting to the formation of the first squares on the bulk of the cotton in any given community. The gradual emergence from hibernation is shown by the number of weevils to 100 stalks in Table III for $190 \pm$ at College Station. In $1903 \mathrm{Mr}$. Teltschick picked the weevils from three-fourths of an acre of trap rows, planted March 13, on which the first bloom appeared May 28, and secured weevils as follows:

April, about 40 weevils.

May 4, 36 weerils picked in 1 hour's time.

May 11, 43 weevils picked in 1 hour's time.

May 18, 68 weevils picked in 2 hours' time.

May 25,54 weevils picked in 4 hours' time.

In $190 t$ Mr. Teltschick made observations especially to determine this point. His notes are as follows:

Two plats of one-fourth of an acre each were selected in that part of the field which was farthest away from my own as also from any other cotton patch. The two plats themselves were separated by 25 rows of corn and surrounded by sugar cane on two sides and by timbered land on the other two. No cotton had been grown on or near these plats in 3 years. Plat 1 was planted in King cotton March 4, was up to a good stand March 14, and chopped to a stand April 11. From plat 1 the weevils were picked as follows:

April 1, 14 weevils.

April 11, 27 weevils.

April 21, 26 weevils.
May 2,96 weevils.

May 12,140 weevils.

May 23, 150 weevils. $a$

Plat 2 was planted in Shine cotton April 25 ( 7 weeks later than plat 1 ), was up to a good stand April 30, and was chopped to a stand May 12 (one month later than plat 1). On plat 1 the first squares appeared May 2 and on plat 2 May 28. All fallen and flared squares were picked up on both plats at intervals of 8 days up to Ju. y 1 . From plat 2 there were picked, on May 12, 3 weevils; May 23, 35 weevils.

These records show very clearly the gradual emergence of the weevils from winter quarters. In 1903 the maximum number of weevils

a Weevils were picked also during June, but these doubtless belonged to the first summer brood. 
appeared on May 18, in 1904 on May 23, and in 1901 on May 10-15: but as the intervals between pickings were a week or 10 dars it would seem safe to judge that the normal time for the maximum number to emerge at Vienna is about May 1 s to 20 . It will also be noticed that the weevils appear much more rapidly and early on early planted cotton, but the maximum number does not appear at the time of squaring of the earliest planted cotton, but at about the time of squaring of the main crop, thus giving a decided adrantage to the early planted cotton. The determination of the exact time of the emergence of the maximum number of weerils will be practically the same as that for the time of maximum oriposition for the hibernating brood. concerning which see page 25 , and which in Lavaca County will nor. mally occur about Mar 20, at College Station about June 1, and in northern Texas probably about June 10.

\section{PREVENTION OF HIBERNATION.}

It may be readily seen from the foregoing discussion that any methods which will reduce the number of weerils going into hibernation in the fall are of the utmost importance in the control of the pest. inasmuch as nature aids in further reducing their numbers during the winter. All students of the problem of boll-reevil control have agreed that in this prevention of successful hibernation lies the most effectual means of reducing the numbers of the reeril and prerenting injury the next season. Two methods are adrocated: (1) The destruction of the stalks in the fall as long before frost as possible. and $(2)$ rotation of the cotton crop, planting on land not in cotton the previous year and as far from such land as is possible.

FALL DESTRLCTIOY OF STALKS.

Br the destruction of the stalls as early as possible in the fall the number of reerils entering hibernation is reduced in sereral wars: (1) All immature stages in the squares and bolls. which might derelop into reerils if the stalks remained standing, will be destrored. Probably three-fourths of the adult weevils in the field at the time of burning may be destroyed if the work be properly managed. (3) $\mathrm{Br}$ clearing the field of cotton some time before the normal time when weevils will enter hibernation their food is destroyed and the adults either stare or migrate to other tields. Were this work done uniformly orer a considerable area. the weerils would surely starre. as they can not be forced into hibernation before the normal time. That a large mortality follows if this is attempted 1s shown in our records (see pages 2-3). These adrantages are apparent. tho but few actual records of the benefit of such fall destruction of stalks hare heen publisherl. From the conditions under which experments must be made it is difficult to demonstrate in a tangible way the actual 
benefit to be thus derived, but in the case of plats burned over in the fall of 1903 we found there were far fewer weevils in 1904 than in fields where the stalks had been left.

On October 23 and 25 the stalks on our experimental plats, covering about 30 acres, were cut with a single cutter made of a $V$-shaped sled, with knives projecting out and backward on either side about a foot beyond the rows. A team draws the cutter with a man on it, cutting 2 rows at once and about 15 acres per day. The stalks were then raked and piled, and were dry enough to burn in a week. On onehalf the field 2 rows in every 20 were left standing as trap rows. No weevils were found later on the dried piles, but they had assembled in large numbers on the standing trap rows. Thirty-six were found on four plants. These trap rows were then cut, left over night on the ground, raked the next morning, and placed on the dried piles. That afternoon examination by the writer showed that on the green stalks on the dried piles there was an average of 1 weevil to every square and boll, often 5 or 6 being found on a square. The torch was then applied and the piles quickly burned. After this many weevils were found on the shoots growing out from the stumpage and an occasional stalk that was left. (This might be obviated more completely by plowing out the stalks.) A herd of cattle was therefore turned into the field and all herbage was devoured in a very few days. A better destruction could hardly be desired, and but little extra labor and expense was involved.

At the apiary a small plat containing two-thirds of an acre was left with the stalks standing all winter. This plat was surrounded by a grove and was half a mile from other cotton.

Observations by the writer show that in 1904 upon the 30 acres upon which the stalks were burned there appeared of the hibernated brood during the spring but 1.2 weevils to 100 stalks, while on the apiary plat where the stalks had been left there were about 4 weevils to 100 stalks, or over three times as many hibernated successfully where stalks remained standing as where they were destroyed.

Again, on July 13 the field where stalks were burned averaged 3.3 weevils to 100 stalks, while fields of Messi's. Boyett and Gray, just over the railroad, not 100 yards distant, where the stalks had not been burned, tho other conditions were practically similar, had 6 and 12 weevils to 100 stalks, respectively, or an average of three times as many weevils as on the field where stalks were burned.

Were all conditions exactly the same, as regards culture, land, etc., and were it possible to prevent the migration of the weevils from neighboring fields to those where the stalks had been burned, the latter would undoubtedly show a much greater yield at the end of the season, but as it is very rarely possible to eliminate these factors the 
abore records show in a striking way, based upon extensive counts, the difference in amount of infestation during early summer where stalks have been destrored the previous fall.

CROP ROTATION.

The value of the rotation of crops was strikingly shown by the difference between the number of weevils occurring on the experiment station variety plats at the college barn, where cotton had been planted the previous year (1902), with corn adjoining, and our plats, situated a mile distant on land which had nerer been in cotton, haring grown sorghum in 1902. tho cotton was grown not 100 rards distant. The cotton was planted April 5 at the college barn, and on June 17 there were 5 weevils to 100 stalks, 2 being found on the 40 stalks examined, whereas on the other field there were but 0.5 to 100 stalks, only 5 being found on $9 \pm 0$ stalks examined. Again, on August 13 the rarieties at the barn, planted May 3, had $2: 33$ weerils to 100 stalks, 163 being found on 70 stalks, while only כ. 5 to 100 stalks occurred in the field where there had been no cotton the prerious rear, only 10 being found on 180 stalks from all parts of the field. On the same day $t S$ weerils to 100 stalks were found on $\mathrm{Mr}$. James Borett's cotton, just across the railroad from our field. his land haring been in cotton the previous year, while on $\mathrm{Mr}$. Suber's cotton, a mile distant, 53 to 60 per 100 stalks were found, this crop also following cotton. ${ }^{a}$

WHERE THE WEETILS FIRST APPEAR.

It has been frequently observed in all parts of the State that the weerils first appear on the cotton field along the side adjoining woodland, if there be any timber adjoining. From the extensire reports of observers thruout the State there seems to be no doubt that cotton in timbered sections is much more seriously injured by the weeril than that on prairie land, owing to the more successful hibernation in the timber. It has also been observed by many that the weerils first appear and commence to be injurious in that part of the field where they were most abundant during the previous year. In southern. Texas the weerils may be found on stubble cotton rerr early in the season: in fact practically all winter. They hardly seem to hiberuate in the strict sense of the word, as under such conditions they are found feeding on warm days practically thruout the winter.

Upon emerging from hibernation the majority of the early weerils seek the earliest cotton. which may be either stubble cotton or planted, and the will be found more abundantly upon it than elsewhere, eren tho the early cotton forms but a very small part of the acreage on a 
large plantation, and altho later cotton may be up, but still small. Having assembled upon the early cotton, most of these weevils seem to stay upon it until it squares, and they do not spread generally to the later cotton until it also commences to square. This habit must be taken into consideration in estimating the number of weevils upon a given area in the spring, for if the cotton be not planted at the same time over the entire place, neither the earliest cotton nor that planted later will give a fair idea of the number of weevils which have hibernated successfully. The total area must be taken into consideration and the average for the whole place estimated by duly weighting the number found upon the acreage of both early and late planting. By the time the majority of hibernated weevils emerge, however, the medium and late-planted cotton will be so far advanced as to hold the weevils near where they emerge, and no further concentration may be expected.

\section{SUMIMER BROODS OF THE WEEVIL.}

The first summer brood of weevils from eggs deposited by the hibernated adults begins to emerge from squares during the last ten days in May in southern Texas, and farther north, in central and northern Texas, continues emerging during June and the first ten days in July. Thus in Lavaca County there is a marked increase in the number of weevils found in the field after June 1 or sometimes during the last week of May. In $1901 \mathrm{Mr}$. Teltschick secured 2,136 weevils up to the third week of May on 10 acres, the maximum appearing during the second week of May; but during the last week of May he secured on the same area 2,114 weevils, or very nearly as many as during the whole spring, showing that the first new brood was then emerging. In 1903, up to June 1, on three-fourths of an acre of trap rows he had picked 241, with a maximum on May 18; but on June 1 he secured 368, and during the month of June 1,759, with the maximum number on the 15 th. In 1904, on the one-fourth-acre plot previously mentioned he secured 453 up to June 1 , the maximum number of 150 on May 23; but on June 4250 were secured and 146 on June 18. Mr. Teltschick writes as follows:

In my opinion very few weevils, if any, matured from punctured squares before June either in this or previous years in this section. Cotton planted here March 1 (this is as early as any is planted, the greater bulk never being planted before April 1) as a rule begins to form squares on April 25. It requires the squares at that time from two to three weeks to grow large enough to provide the food necessary for the development of the weevil. The squares are, of course, being punctured as soon as they form, and I doubt whether any eggs are deposited in them so long as they are too small to permit the weevil secreting itself within the involucre.

At College Station the first fallen squares were found on June 17, 1904. The first weevils from these squares emerged June 23 and the 7036-Bull, 63-09-3 
last on June 29. At Terrell, Tex., the first brood commenced to emerge on June 30 and the last of these was secured on July 12.

Altho the hibernating weevils may continue to oviposit for some time there seems to be but little overlapping in the appearance of the first and second generations of weevils. There is a period from the first to the middle of July thruout the greater part of the infested area when but little damage is reported from the weevil and when but few weevils are found. This is the period during which the second brood is developing within the squares. About the middle of July and during the next ten days the second brood of weevils appears and is generally reported. In some instances the injury by the second brood is serious, especially where large numbers have hibernated successfully, and after the second brood appears practically all the squares become punctured and no more cotton is made. This condition is more common in southern Texas, but usually the injury by the second brood is no more serious than that due to the first in late June, and in a great many cases it is reported as being decidedly less. In general, unless there be exceptional rains, the hot suns of July seem to check the development and injury of the weevil.

The distinction between the second and third broods is not so marked. The period of oviposition of the second brood doubtless being longer than that of the first, the third brood commences to appear before the last of the second brood has emerged. However, there is still a very decided and notable increase in the number of weevils from the first to the middle of August, depending upon the latitude and season. This is generally noticed, and commonly reported as the third brood. Usually with the emergence of this brood the weevils have become sufficiently numerous to destroy all the squares as they form so that no more blooms are seen. From this time the weevils attack the maturing bolls much more frequently. After the appearance of the third brood the different generations become so involved that it is impossible to distinguish between them.

At Terrell, Tex., five distinct broods were reared in $190 t$ up to October 3, and these weevils then commenced to oviposit, so that there would doubtless have been a maximum of six complete broods in that locality. The records at Terrell are as follows: From the first fallen squares injured by the hibernated brood, weevils emerged on June 30 , July 5, and July 12 . On July 5 these weevils were placed in a cage upon fresh squares, and the weevils developing from these squares emerged on July 22, or in from 17 to 22 days. These were placed on squares on July 23 , and the weevils from them, or the third brood, emerged August 17 to 20, or in 25 to 28 days. These weevils were placed on squares August 20, and the weevils developing from them, or the fourth brood, emerged September 8 and 9, or in 19 to 20 days. These were placed on squares September 10, and the weevils 
developing from them, or the fifth brood, emerged October 3 , or in 23 days. In all cases this period of development includes to a greater or less extent the feeding period, which must precede oviposition.

Practically the same number of generations seems to occur at College Station. Altho we have not determined this by rearing weevils as rapidly as possible thruout the season, the field records show the first three broods very distinctly, and during the fall there seem to be three more broods between September 1 and the time of hibernation. The number of broods after September 1 is very largely controlled by the temperature and rainfall, which combine to affect the food supply and the mortality of the developing weevils. It is probable, however, that in a late season seven broods might develop at College Station, as the field records (see page 10, Table II, for 1903) show the weevils (probably of the sixth maximum brood) to have been freely ovipositing early in November, and if frosts did not occur until late in that month a large number of these would probably emerge.

In southern Texas, Hunter and Hinds have shown that with the average season of reproductive activity, extending from May 1 to November 15, eight generations may be produced during the year. Thus there is probably a difference of two broods in the maximum number of generations between southern Texas and northern Texas, but this difference will not materially affect either the injury by the weevil or the number of weevils going into hibernation, as the weevils seem to reproduce in practically the same length of time in northern Texas as in southern 'Texas, the summer temperature being nearly the same, and after the third brood they are sufticiently numerous in either section to prevent the further fruiting of the crop. Nevertheless, factors aside from a difference in the number of generations will probably cause less damage in northern Texas.

By September 1 to 15 the weevils usually reach the maximum number and during the fall, as before observed, their number depends primarily on the food supply and weather conditions, so that the number going into hibernation depends on local conditions. The difference in the amount of injury which the weevil may do in central or northern and in southern Texas will depend therefore, first, upon the smaller number of weevils hibernating successfully and, second, upon their appearing later in the spring so that the cotton may be able to make a more rapid growth in comparison with the development of the early broods of the weevil under the high temperatures prevailing during early summer in northern Texas than will be the case farther south in late May. But it is not probable that the mere number of broods will make any material difference in the amount of injury. The first three broods seem to be well defined, as is clearly shown by the numerous reports of our voluntary observers and by the reports of the observers of the crop service of the U. S. Weather Bureau. The amount of 
injury done depends upon the abundance of these broods, which depends largely upon the time of appearance and also upon the relative abundance of the hibernating brood.

\section{MORTALITY OF SUMMER BROODS.}

The mortality occurring in summer and fall broods may properly be distinguished from that among weevils which hibernate, for in the summer the greatest mortality occurs in the immature stages. The number of weevils developing from squares in which eggs have been laid is shown in Table IV.

TABLE IV.-Percentage of weevils from infested squares.

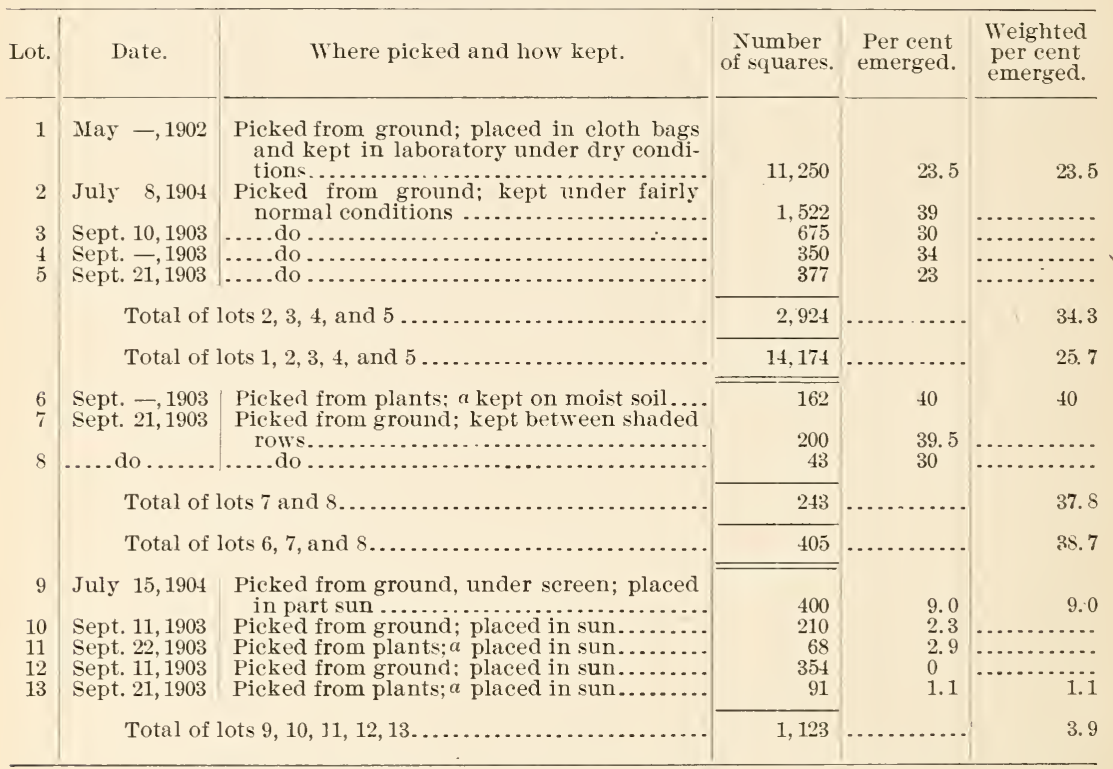

a Picked from plants when squares would drop off by touching them.

Lot 1 is based upon the following note made by Mr. Wilmon Newell. During May, 1902, Professor Mally gathered infested squares in fields along the Brazos River below Wellborn. About $1 \frac{1}{2}$ bushels of these squares were brought to College Station, sewn up in cheese-cloth sacks, and weevils allowed to hatch. June 15 the weerils were picked out and by careful measurement there were $115 \mathrm{c}$. c. of them, and 15 c. c. contained 345 weerils, or 1,763 weerils to a bushel. Subsequently we have found about 7,500 squares in a bushel, thus indicating that only about 23.5 per cent produced weevils. The squares were kept in the laboratory in a dry place, and the lack of moisture may probably account for the low percentage producing adults. In another test 2.924 squares gave a weighted arerage of $3 \pm$ per cent producing weevils. These were picked up and kept under fairly normal condi- 
tions. From 405 squares which were kept on moist soil or between shaded rows weevils were developed from 38.6 per cent, but where the squares were left in the hot sun, among 1,123 squares but 1 per cent produced weevils. This shows strikingly the value of having rows wide apart so that the sun may strike the fallen squares.

TABLE V.-Percentage of mortality of weevils at different stages of development.

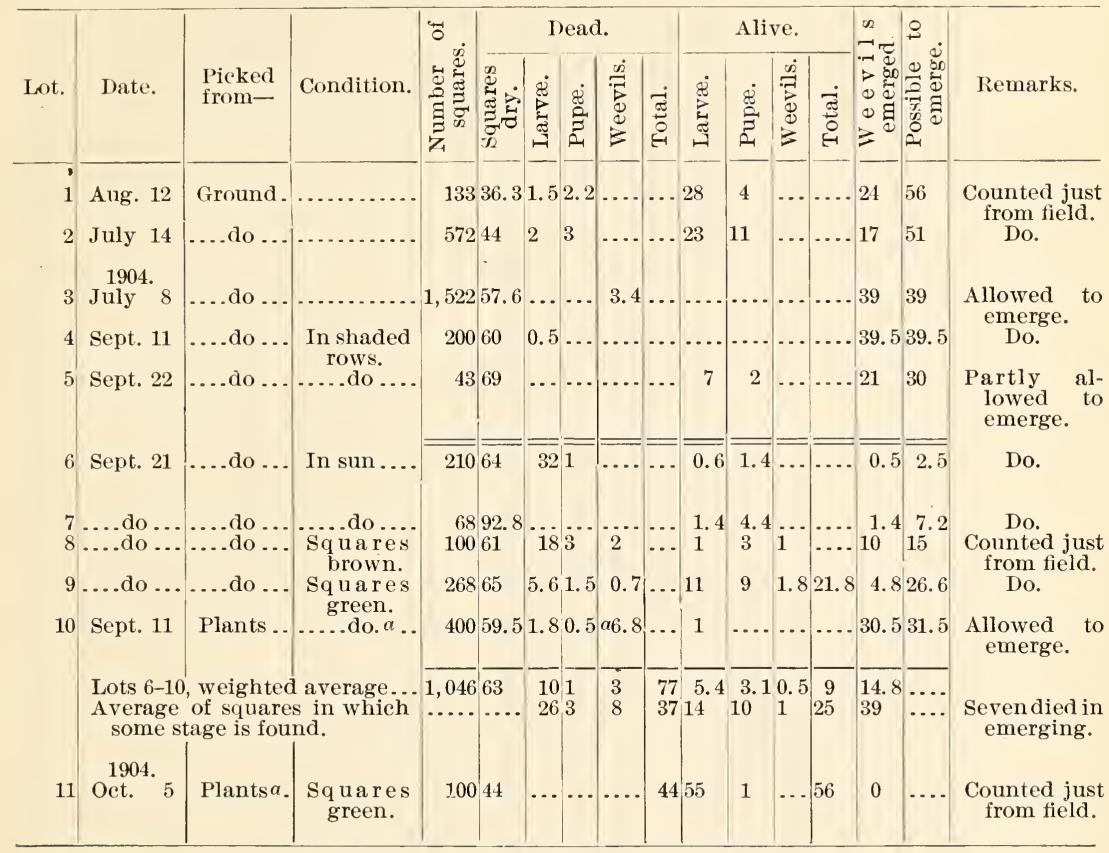

$a$ Squares picked from plants when just ready to drop.

The count made on October 5, 1904, fully confirms this. These squares were picked from the plants, taking those that would drop into the hand when touched, as in previous similar work. An immediate examination showed that 55 per cent contained live larvæ of various sizes, but mostly about half grown. Tho a few were ready to pupate, but one pupa was found, while there were 44 in which the work of young larvæ was clearly recognizable but in which no larva could be found. All squares showed egg punctures, but no eggs could be found in them.

The time at which the greatest mortality in the development of the weevil occurs is a matter of some practical importance and the data given in Table $\mathrm{V}$ throw considerable light upon this point. We have but few observations as to the mortality in the egg stage, but Hunter and Hinds state that but few eggs fail to hatch, which we have found to be the case in the laboratory. As the square receiving an egg does 
not fall for about 10 days and remains green long after the hatching of the egg, which takes place in about 2.5 days, there seems no reason to suspect any considerable mortality at this period. After the infested squares have dried or decayed it becomes very difficult to find any trace of larræ which die before they are half or two-thirds grown. The table shows that in about 63 per cent of the infested squares no trace of weeril stage could be found. In this percentage are the squares which had receired feeding punctures only and a large number showing external signs of egg punctures, thus indicating that a great mortality occurs while the larvæ are less than half grown. Furthermore, it will be observed that of those individuals which pass the larval stage succesfully 1.6 per cent died in the squares or while emerging. It has previously been shown that only about 1 per cent of squares placed where fully exposed to sunshine dereloped weerils. It woutd therefore appear that the mortality was largely due to the squares becoming so dried that the food supply was cut off from the young larra. Hence, it would seem that the sooner the square falls after being punctured, the higher will be the mortality, provided the ground is not shaded by close rows, and that any means for knocking off the squares before they would naturally fall, or a variety or strain of cotton which sheds its squares more quickly after being punctured, will be of decided adrantage in increasing the mortality of the weevil. This seems to be eren more marked where the squares are corered by the soil as is shown in Table VI.

TaBle VI.-Percentage of mortality of weerits in squares buried in soil.

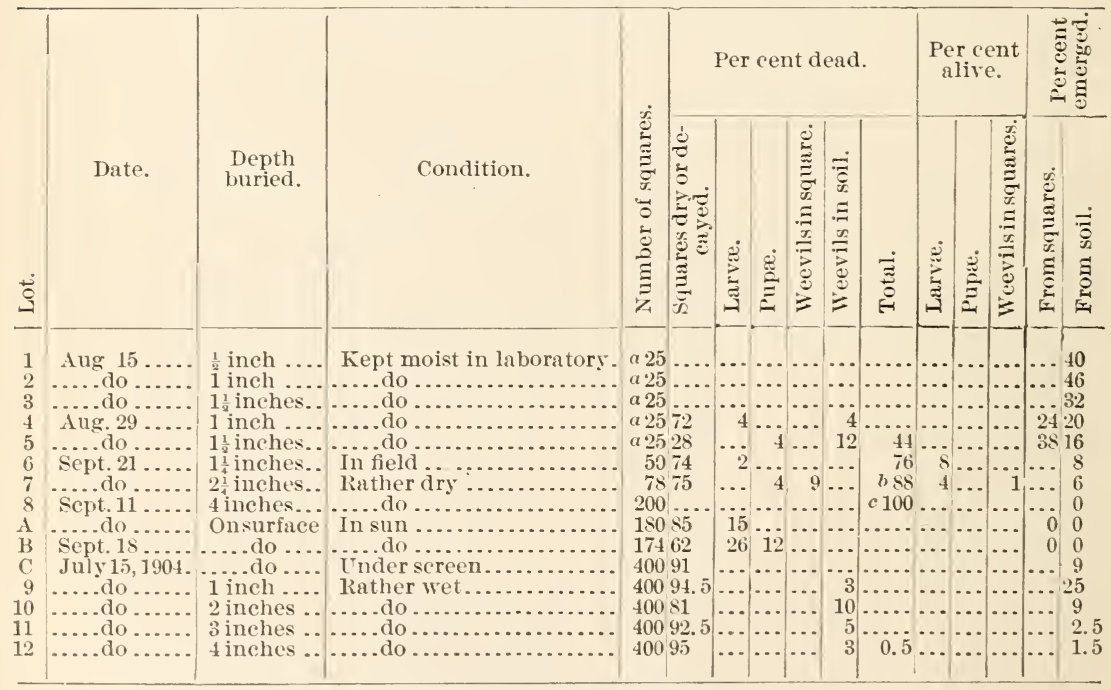


It is frequently asserted that frequent cultivation is of value against the weevil in that the immature stages are killed by covering the squares with soil. The data given in Table VI hardly confirm this. Rarely will squares be buried over 1 or 2 inches. Lots 1, 2, 3, 4, 5, 9 , and 10 show that the mortality in squares buried at this depth is about the same as under normal conditions. Lots 6 and 7 seem to show a benefit from burial, but these were placed in rather dry soil in the field in open sun, and when compared with lots A and B on the surface it is seen that the burying insured a greater per cent developing. It seems safe to say that in no case will burial for not over 2 inches result in any great mortality, and that in all probability the percentage of weevils developing will be greater than if left exposed to the sun on the surface. It is more frequently claimed that by plowing squares under deeply after a good rain the moist soil will rot them and the weevils will be unable to escape. Unfortunately we have no conclusive tests upon this point, but it would seem that a sufficiently deep plowing to bury squares 4 inches just after a rain would be such a decidedly bad agricultural practise as to possibly offset any benefit that might be derived from destroying the weevils in the squares buried.

RATE OF INCREASE OF TIIE WEEVIL.

Hunter and Hinds have shown that a female weevil normally lays some 150 eggs during an average of about 54 days, and that nearly one-half of the eggs are deposited during the first third of the period of oviposition. Allowing 24 days for the development of the average adult and 18 days for the oviposition of one-half of the eggs, they also estimate that the average length of a generation is about 42 days. The sexes of the weevil are produced in about equal numbers. With these factors as a basis we may easily compute that if on June 1 there were an average of 2 weevils to 100 stalks of cotton, on July 15, at the end of the first theoretical brood, there would be 50 weevils; and that, if one-half of these were females and the usual percentage survived, on September 1 there would be 1,250 weevils to 100 stalks. But these computations make no allowance for the mortality in the immature stages, and extended observations in the field show that such rapid multiplication does not really occur. It has been ascertained by the writer that the first brood of weevils rarely numbers more than five times the hibernated brood, and at College Station often but two or three times. At Vienna, in 1903, Mr. Teltschick picked 241 weevils from his trap rows up to June 1, while on June 1 to 7,15 , and 22 he picked 759 weevils on the same area. This doubtless represents very accurately the increase of the first brood over the hibernated weevils, showing an increase of 315 per cent. It is of course probable that some weevils had left the trap rows for the planted cotton, which was barely commencing to square 
on June 22, but the number would have been comparatively small and the end of the generation was probably considerably later, so that an increase of ten times, or 1,000 per cent, would be a conservatire estimate. The largest number of weevils at College Station early in July was found on Eckol's cotton, which was planted rery early, on July 14, 1904, when there were 27 weevils to 100 stalks. 'This field was adjoining a gin and 1 mile away, on Ayer's cotton, there were but 15 weevils to 100 stalks. On the same date, on the Brazos River, there were but 10 weevils to 100 stalks, and on our experimental plats, where the stalks were destroyed the previous fall, the hibernated brood had numbered barely 1 weeril to 100 stalks. There were but 3.3 weerils of the first brood to 100 stalks. Accurate figures for the rate of increase from the first to the second brood are not arailable, but from general observations and from reports of the injury done by the second brood, as compared with the first, it is safe to assert that the rate of increase is not materially greater for the second brood than for the first. The rate of increase of the third brood seems to be decidedly greater, but, as the late-developing individuals of the second brood and the first of the third brood more or less overlap, it is difficult to determine this accurately in the field. Howerer, the total increase at the appearance of the third brood over the number of hibernated individuals can be given in one or two cases. Along the Brazos River, in 1903, there were but 2 weevils to 100 stalks on June 17, and on August 2547 weerils to 100 stalks, or an increase of twenty-three times between these dates, the collection at the latter date probably representing part of the fourth brood. In 1903, at the college on our experimental plats, there were 5.5 weerils to 100 stalks on August 13 where there were 1.5 on June 18, representing the hibernated brood. The greatest increase we have observed from the hibernated brood until the middle of August was on the plat of the experiment station at the college barn in 1903, where there were 5 hibernated reevils to 100 stalks on June 18 and 233 on August 13, or an increase of forty-seven times. From a careful study of the data it seems safe to assert that the usual rate of increase from the second to the third brood is not over ten or fifteen times in this section, as there is usually not over 1 weevil to the stalk of cotton until after midAugust. It will be seen, therefore, that tho the theoretical increase of the weevil, based upon a careful study of its habits and the mortality as far as can be ascertained, would show an increase of trentyfive times from between the first and second and second and third theoretical broods of 42 days each from June 1 to September 1 , as a matter of fact, during the first period mentioned, the increase up to and including the second brood, emerging about the third reek in July, is usually considerably less than twenty-fire times the hibernated brood-probably not over fifteen times-and that the total increase 
from the 1st of June to the 1st of September is only about fifty times, certainly not over sixty-five times, where theoretically it would be six hundred and twenty-five times. The reason for this discrepancy is unknown to the writer, but is a fact for which the cotton planter should be decidedly thankful. It may be that the mortality of the immature stages of the weevil in the squares is greater than the count of thousands of squares has shown, that many of the adult weevils die or are destroyed before reproducing, or that the number of eggs laid and the length of the period of oviposition in the field are much less than those observed in the laboratory. That this is true of the hibernated brood is shown on page 12. It would seem that the discrepancy is mostly due to the two latter factors. This discrepancy but emphasizes the necessity for accurately observing the field conditions on a very large scale in different fields in different sections of the State constantly thruout the season if we are to obtain accurate knowledge of the true habits, rate of increase, and injury of the boll weevil, as it occurs in the field.

To summarize briefly, it would seem that if there be 2 weevils to 100 stalks of the hibernated brood, then by early in August there will be a sufficient number of weevils to stop the blooming of the cotton. Furthermore, with the normal increase it seems that in about a month after 4 or 5 weevils are found on 100 stalks, there will have been sufficient increase to prevent further fruiting of the cotton, and there will then be from 75 to 100 weevils to 100 stalks. The utter impossibility of making a cotton crop where a large percentage of the weevils survive the winter will therefore readily be seen unless exceptional measures can be taken to check their multiplication. Weather conditions unfavorable to the development of the weevils are decidedly the most important controlling factors, and that such conditions not infrequently occur is shown by the reports of voluntary observers in southern Texas in 1904.

INJURY TO SQUARES IN RELATION TO THE NATURAL INCREASE OF SQUARES.

The formation of squares upon the cotton plant depends upon so many different factors that it is exceedingly difficult to make any general statements regarding the increase in their numbers. Thus the character of the soil, the nature of the variety of cotton, and the climatic conditions prevailing all influence the formation of squares. It may be clearly seen from Tables VII to $\mathrm{X}$ that some varieties form squares much faster than do others, and that between the same dates the same variety will not produce the same number of squares in different places. However, from an examination of the tahles we may form some idea of the natural increase of the squares early in the season during the critical period of fruit formation. During the 2 
weeks following the formation of the first 2 squares the number of squares will increase ten or twelve times; in other words, there will be from 20 to 25 squares; and during the next 2 weeks this number will increase two times, or at the end of the month there will be about 40 squares, or about twenty times as many as at the beginning of the month, when there were but 2 squares. At the end of the second month there will be an increase of about two times orer the first month, or there will be approximately 100 squares to the plant. During the first third of the third month the number of squares usually remains about constant, but after that, tho squares are constantly forming, there is a tendency to decrease for a time.

TABLE VII.-Progress of infestation by boll weevil and production of fruit upon cotton plats at College Station, Tex., in 1903.

\begin{tabular}{|c|c|c|c|c|c|c|c|c|c|c|c|c|c|c|c|c|c|c|c|}
\hline \multirow[b]{3}{*}{ Variety. } & \multirow{3}{*}{ 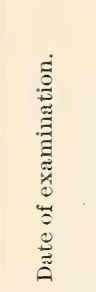 } & \multirow[b]{3}{*}{ 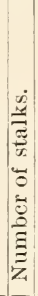 } & \multirow{2}{*}{\multicolumn{4}{|c|}{ Squares. }} & \multirow{2}{*}{\multicolumn{2}{|c|}{ Blooms. }} & \multirow{2}{*}{\multicolumn{4}{|c|}{ Bolls. }} & \multirow{2}{*}{$\begin{array}{l}\text { Wee- } \\
\text { vils. }\end{array}$} & \multicolumn{6}{|c|}{ Yield per acre. } \\
\hline & & & & & & & & & & & & & & \multicolumn{5}{|c|}{ Pounds of seed cotton. } & \\
\hline & & & 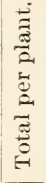 & 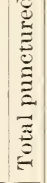 & 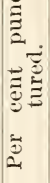 & & $\stackrel{\vec{\pi}}{\overparen{\pi}}$ & $\begin{array}{l}\vec{\Xi} \\
\vec{\Xi} \\
\vec{\Xi} \\
\vec{U}\end{array}$ & 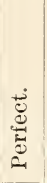 & $\stackrel{\Xi}{ٍ}$ & 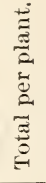 & 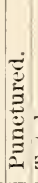 & 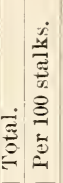 & $\stackrel{\stackrel{\oplus}{\rightleftarrows}}{\stackrel{\tilde{\sigma}}{\Xi}}$ & 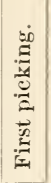 & $\stackrel{\stackrel{D}{\rightleftarrows}}{\stackrel{\Xi}{\Xi}}$ & 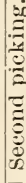 & 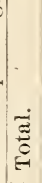 & 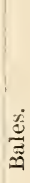 \\
\hline \multirow[t]{3}{*}{$\begin{array}{l}\text { Jones Im- } \\
\text { proved.. }\end{array}$} & une 18 & 20 & $\frac{1}{2}$ & & & & & & & & & & & & & & & & \\
\hline & $\begin{array}{ll}\text { July } & 11 \\
\text { July } & 27\end{array}$ & $\begin{array}{l}25 \\
30\end{array}$ & & 11 & $\begin{array}{r}0.9 \\
.7\end{array}$ & & $\begin{array}{r}8 \\
37\end{array}$ & $\begin{array}{l}0.3 \\
1.2\end{array}$ & $\begin{array}{r}1 \\
138\end{array}$ & & 4.6 & & & & & & $\cdots$ & & \\
\hline & ug. 12 & 10 & & & 9.1 & 70 & & 3 & 126 & ... & 12 & & & & & & & & \\
\hline \multirow{3}{*}{ Allen ..... } & $\begin{array}{l}\text { Sept. } 5 \\
\text { June } 18\end{array}$ & $\begin{array}{r}5 \\
20\end{array}$ & $\begin{array}{l}34 \\
1.5\end{array}$ & & 56 & 127 & $\cdots$ & 0 & 25 & 6 & $\begin{array}{c}6 \\
\ldots\end{array}$ & 7 & $\begin{array}{ll}1 & 20\end{array}$ & Sept. 17 & 104 & Oet. 20 & 98 & 3202 & \\
\hline & July 11 & 25 & & & & $\cdots$ & 23 & 1 & 12 & .. & .5 & $\ldots$ & $\ldots$ & & $\cdots$ & & $\cdots$ & & \\
\hline & $\begin{array}{l}\text { Aug. } 12 \\
\text { June } 18\end{array}$ & $\begin{array}{l}10 \\
20\end{array}$ & & 2125 & 35 & 50 & & 3.8 & 208 & & & 30 & $\cdots \cdots$ & Sept. 17 & $17 \mathrm{~S}$ & Oet. 20 & 80 & 258 & \\
\hline \multirow{2}{*}{ Excelsior } & July 11 & 25 & & 3 & .4 & $\ldots$ & 11 & .5 & 10 & & .4 & . & $\ldots$ & & $\ldots$ & .......... & -. & & \\
\hline & $\begin{array}{l}\text { Aug. } 12 \\
\text { Sept. } 5\end{array}$ & & $\begin{array}{l}14.7 \\
20.5\end{array}$ & $\begin{array}{r}59 \\
132\end{array}$ & & $\begin{array}{r}42 \\
110\end{array}$ & & $\begin{array}{c}3 \\
\cdots\end{array}$ & $\begin{array}{r}119 \\
4\end{array}$ & $\ddot{8}$ & $\begin{array}{r}12 \\
6\end{array}$ & $\begin{array}{r}6 \\
20\end{array}$ & $\begin{array}{lll}\because & \cdots & 80\end{array}$ & Sept. 16 & 17\% & Oet. 20 & $\ddot{9}$ & 264 & \\
\hline \multirow[t]{2}{*}{ Parker.... } & June 18 & 20 & 1.9 & $9 \ldots$ & $\ldots$ & & & & & .. & $\cdots$ & .. & .... & .......... & ... & . . & .. & $\ldots$ & \\
\hline & $\begin{array}{l}\text { July } 11 \\
\text { Aug. } 12\end{array}$ & & & & $15^{*}$ & $\cdots$ & & .5 & $\begin{array}{r}11 \\
211\end{array}$ & $\because$ & $22^{.5}$ & $\because 6$ & $\cdots$ & Sept. 16 & 184 & Oct 20 & 60 & & \\
\hline \multirow[t]{2}{*}{ Griffith.... } & June 18 & 20 & 1.5 & 52 & 6. & & & $\cdots$ & $2=1$ & & & $\ldots$ & 210 & & .... & ......... & .. & & \\
\hline & July 11 & 25 & & 14 & 6 & $\cdots$ & 13 & $\therefore 5$ & & .. & .24 & is & $\because \cdots$ & & & & & & \\
\hline \multirow{4}{*}{ King ....... } & June 18 & $\begin{array}{l}10 \\
20\end{array}$ & $\begin{array}{r}28.9 \\
2.5\end{array}$ & & & & & & 09 & & & 10 & $\begin{array}{cc}0 & 00 \\
. . & \ldots\end{array}$ & sept. 18 & 156 & (?) & (?) & (?) & \\
\hline & $\begin{array}{ll}\text { July } & 11 \\
\text { July } & 27\end{array}$ & & & & & & $\begin{array}{l}13 \\
12.7\end{array}$ & $\begin{array}{r}.5 \\
2.5\end{array}$ & $\begin{array}{r}24 \\
486\end{array}$ & & $\begin{array}{l}1 \\
9\end{array}$ & & .... & & $\cdots$ & & & & \\
\hline & ig. 12 & & 47.5 & 557 & 12 & 97 & 51 & 5 & 233 & $\ldots$ & 23 & & 330 & & $\cdots$ & & & & \\
\hline & Sept. 5 & & & 144 & & 160 & & … & 20 & & & 251 & $11 \mid 220$ & Sept. 16 & 290 & Oct. 20 & & 358 & \\
\hline
\end{tabular}


TABLE VIII.-Comparison of progress of infestation by boll weevil and production of fruit upon variety plats on Carson \& Smith's plantation, Brazos River, Wellborn, Tex., in 1903.

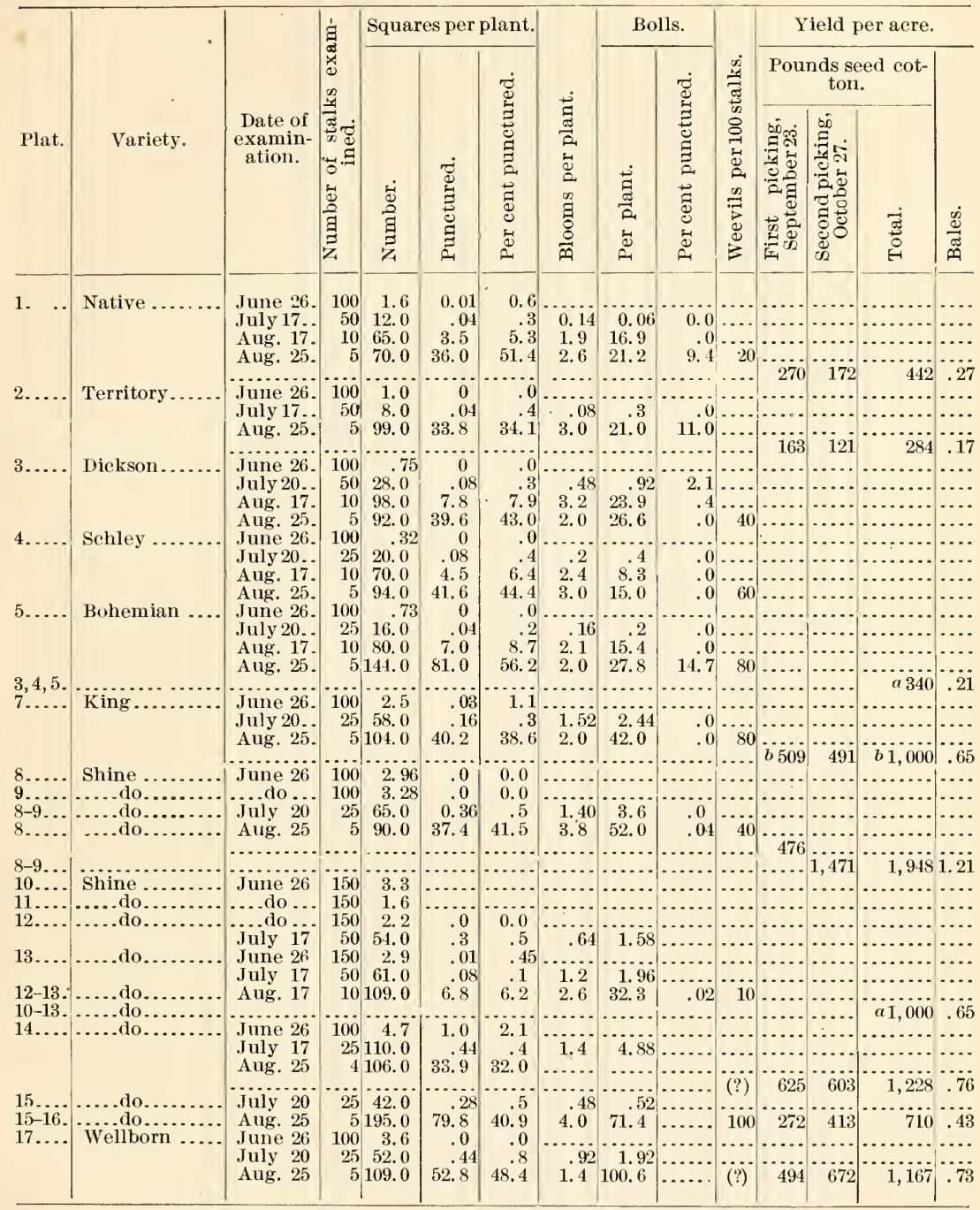


TABLE IX.-Comparison of progress of infestation by boll weevil and production of fruit upon plats of cotton planted at different dates by August Scholl, Hunter, Tex., in 1903.

\begin{tabular}{|c|c|c|c|c|c|c|c|c|c|c|c|c|c|c|c|c|}
\hline \multirow[b]{3}{*}{ 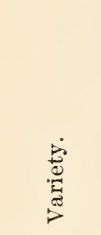 } & \multirow[b]{3}{*}{ 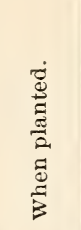 } & \multirow{3}{*}{ 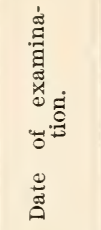 } & \multirow[b]{3}{*}{ 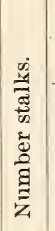 } & \multirow{2}{*}{\multicolumn{3}{|c|}{$\begin{array}{l}\text { Squares per } \\
\text { plant. }\end{array}$}} & \multirow{2}{*}{ ت્छુ } & \multirow{2}{*}{\multicolumn{2}{|c|}{ Bolls. }} & \multirow{3}{*}{ 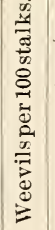 } & \multicolumn{6}{|c|}{ Yield per acre. } \\
\hline & & & & & & & & & & & \multicolumn{5}{|c|}{ Pounds seed cotton. } & \multirow{2}{*}{ ल्ष } \\
\hline & & & & 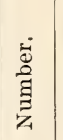 & 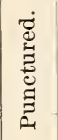 & 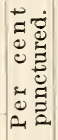 & 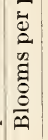 & 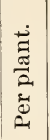 & 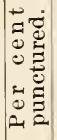 & & 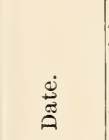 & 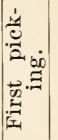 & 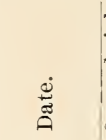 & 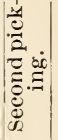 & & \\
\hline hin & Mar 1. & $\begin{array}{l}\text { ay } 30 . . \\
\text { aly } 3 . .\end{array}$ & $\begin{array}{r}140 \\
15\end{array}$ & $\begin{array}{r}3.0 \\
40.0\end{array}$ & $\dddot{4} .0$ & 10.0 & & & & & & & & & & \\
\hline & & $\begin{array}{l}\text { Aug. } 5 . \\
\text { Aug. } 28 .\end{array}$ & $\begin{array}{l}195 \\
\text { Av. }\end{array}$ & 195.0 & & 43.1 & 2.2 & $\begin{array}{l}9.6 \\
24.0\end{array}$ & 37.5 & 140 & Sept. 26 . & 171 & Dec $1 \ldots$ & $14^{2}$ & 313 & $\because 2 \mathrm{i}$ \\
\hline Native. & Mar... & $\begin{array}{l}\text { July } 3 . . \\
\text { Aug. } 5 . .\end{array}$ & $\begin{array}{r}15 \\
5\end{array}$ & $\begin{array}{l}19.0 \\
80.0\end{array}$ & $\begin{array}{l}3.06 \\
33.0\end{array}$ & $\begin{array}{l}316.1 \\
41.2\end{array}$ & 2.0 & & & $\cdots$ & & & 200.1. & .... & & $\cdots$ \\
\hline & Apr.1. & $\begin{array}{l}\text { Aug. } 28 . \\
\text { May } 30 . \\
\text { July } 3 .\end{array}$ & $\begin{array}{l}\text { A v. } \\
\cdots \\
-50 \\
5\end{array}$ & $\begin{array}{r}\cdots .0 \\
50.0\end{array}$ & & & & 6.0 & & $\cdots$ & Sept. 26. & 210 & Dec. $1 .$. & 148 & $\begin{array}{c}358 \\
\cdots \\
\cdots\end{array}$ & $\begin{array}{l}.24 \\
\cdots . \\
\cdots .\end{array}$ \\
\hline Shine. & Apr... & $\begin{array}{l}\text { Aug. } 5 . . \\
\text { Aug. } 28 . \\
\text { July } 3 . . \\
\text { Aug. } 5 . .\end{array}$ & $\begin{array}{r}5 \\
\text { Av. } \\
50 \\
5\end{array}$ & $\begin{array}{r}57.0 \\
20.0 \\
97.0\end{array}$ & $\begin{array}{l}7 \\
0\end{array}$ & & 1.8 & $\begin{array}{l}12.0 \\
19.0\end{array}$ & 20.0 & \begin{tabular}{c}
140 \\
$\cdots$ \\
\hdashline 120
\end{tabular} & Sept. 26. & $\begin{array}{c}78 \mathrm{i} \\
\cdots\end{array}$ & oct. 15. & 278 & $\begin{array}{l}360 \\
\cdots \cdots\end{array}$ & 30 \\
\hline Nativ & Apr... & $\begin{array}{l}\text { Aug. } 28 . \\
\text { July } 3 . \\
\text { Aug. } 5 . .\end{array}$ & $\begin{array}{r}\text { Av. } \\
50 \\
5\end{array}$ & $\begin{array}{l}31.0 \\
12.0 \\
53.0\end{array}$ & $\begin{array}{l}1.62 \\
24.6\end{array}$ & $\begin{array}{l}4.0 \\
13.5 \\
46.4\end{array}$ & $\begin{array}{l}2.0 \\
\cdots 6\end{array}$ & $\begin{array}{l}13.0 \\
\dddot{5} .8\end{array}$ & $\frac{10.0}{37.5}$ & $\begin{array}{l}120 \\
\cdots . . \\
-80\end{array}$ & 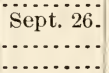 & $\begin{array}{c}\cdots 50 \\
\cdots \\
\cdots\end{array}$ & Dec. $1 \ldots$ & 120 & $\begin{array}{c}270 \\
\cdots \\
\cdots\end{array}$ & .18 \\
\hline Native. & Apr... & $\begin{array}{l}\text { dug. } 28 . \\
\text { July } 3 . . \\
\text { Aug. } 5 . .\end{array}$ & $\begin{array}{r}\text { Av. } \\
50 \\
5\end{array}$ & $\begin{array}{r}\ldots . .0 \\
23.0 \\
42.0\end{array}$ & $\begin{array}{l}\because 3.34 \\
19.6\end{array}$ & $\begin{array}{l}17.5 \\
46.6\end{array}$ & $\begin{array}{l}\cdots \\
1.0\end{array}$ & $\begin{array}{r}5.0 \\
12.4\end{array}$ & $\begin{array}{c}\cdots \\
\cdots 4.1\end{array}$ & \begin{tabular}{c}
$\cdots$ \\
\hdashline 140 \\
140
\end{tabular} & Sept. 26 . & $\begin{array}{c}173 \\
\cdots .\end{array}$ & Dec.1.. & $\dddot{57}$ & 230 & .15 \\
\hline Shine. & May & $\begin{array}{l}\text { Aug. } 28 . \\
\text { July } 3 .\end{array}$ & $\begin{array}{l}\text { Av. } \\
100\end{array}$ & & & & $\cdots$ & 11.0 & & & Sept. 26 . & 366 & Nov. $1 .$. & 57 & 423 & .28 \\
\hline Native.. & May 1. & $\begin{array}{l}\text { Aug. } 5 . . \\
\text { Aug. } 28 . \\
\text { July } 3 . . \\
\text { Aug. } 5 . .\end{array}$ & $\begin{array}{r}5 \\
\text { Av. } \\
100 \\
5\end{array}$ & $\begin{array}{r}62.0 \\
\cdots .7 \\
36.0\end{array}$ & $\begin{array}{l}18.2 \\
\cdots \ldots . \\
16.2\end{array}$ & 45.0 & $\begin{array}{l}.2 \\
\cdots \\
\cdots 2\end{array}$ & $\begin{array}{c}2.4 \\
3.0 \\
\cdots .6\end{array}$ & $\begin{array}{l}8.3 \\
\cdots \\
33.3\end{array}$ & $\begin{array}{c}160 \\
\cdots \cdot \\
\cdots \\
40\end{array}$ & Dec.1.. & 80 & & & $\begin{array}{r}80 \\
\cdots\end{array}$ & $\begin{array}{r}.05 \\
\cdots\end{array}$ \\
\hline & & & & & & & $\cdots$ & & & & & & & & & \\
\hline
\end{tabular}


TABLE X.-Comparison of progress of infestation by boll weevil and production of fruit upon plats of cotton at College Station, Tex., in 1904.

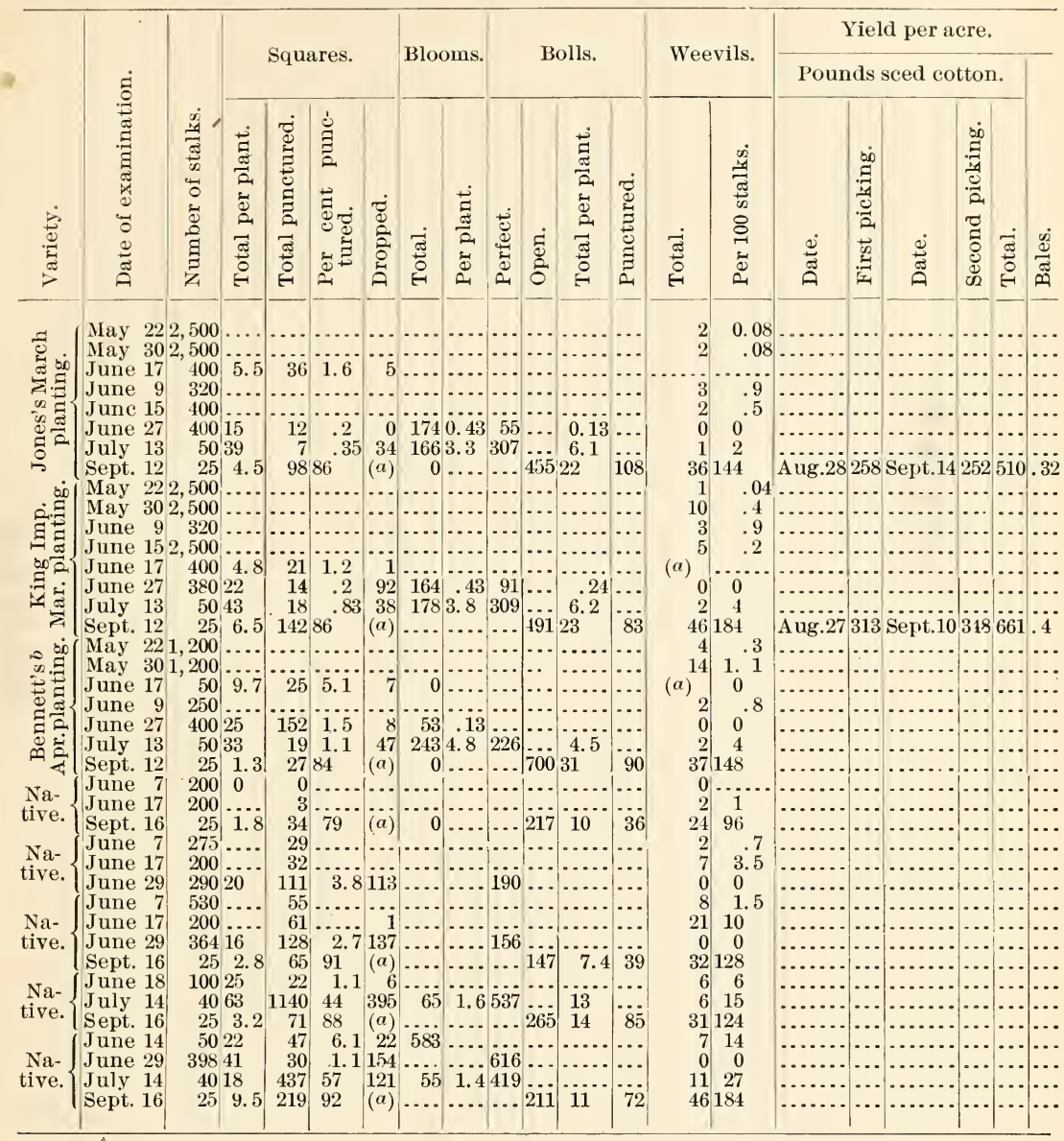

$a$ Not counted.

$b$ Consisted of a large number of varieties.

NoтE.-The five plats of native cotton referred to were planted by different farmers in the vicinity of College Station.

The proportion of squares punctured by the end of the first month after squares have commenced to form has been found to range from 2.5 to 10 per cent. It is usually not over 5 per cent, and an average proportion of 3 per cent would be more nearly correct. Thus, on the Brazos River, July 13, 1904, but 8 per cent of the squares were punctured. At the College on our main plats less than 1 per cent were punctured. At Eckol's, on June 14, 1904, 6.1 per cent were punctured and on June 29 but 1.1 per cent. In 1903 at the College not over 2 per cent were punctured during the first month of square formation. In the Brazos bottom in 1903 the proportion was less than 1 per cent. In 1901, on June 17, Mr. Teltschick reported to Professor 
Mally that 10 per cent of the squares were punctured upon cotton which had been squaring for 5 weeks. At the end of the second month of square formation there is an increase of from ten to fifteen times in the percentage of punctured squares. On August 13. 1903, an arerage of 35 per cent of thè squares on our plats were punctured, and on August 25 on Smith \& Carson's plantation there were 42 per cent. On August 13, on the experiment station plat at the College barn, there were 65 per cent, these representing the injury done upon the emergence of the third brood of weerils. On July 14, 1904, Eckol's and Ayer's cotton had $5 \tau$ and 44 per cent punctured, this being about 2 months after the first squares formed. In a general way, it seems safe to say that usually 50 per cent of the squares will be punctured by about 2 months after the cotton commences to square, at which time, as we have seen, there would normally be about 100 squares to the stalk. With the appearance of the third brood of weevils early in August the percentage of injury rises rapidly, and by September 1 from 85 to 90 per cent of the squares will be found punctured, tho it is rather unusual to find orer 90 per cent of the squares punctured in this section when they are carefully counted. In 1904 , at the end of 6 weeks of square formation, there were but 8 per cent of the squares punctured along the Brazos River, tho on the oldest cotton, which had been squaring about 2 months, where the weevils were thickest, $t 0$ per cent were punctured. When one-half of the squares are punctured it may be readily concluded that there are probably sufficient weerils present to prevent any more squares from forming fruit. It will be seen, therefore, that the critical period in the relation between natural increase of squares on the plant and the increased injury by the boll weevil is during the period of 6 to 8 weeks after first squaring, which usually coincides more or less closely with the time between the appearance of the second and third broods of weevils. Thus, if we consider 6 weeks as the average time required for cotton to begin to square after planting, it will be seen that the bulk of the fruit must be set in 55 or 90 days after planting. In other words, it may be readily seen that to escape injury by the boll weeril cotton must be so grown that the bolls will commence to open in about 100 days after planting, and that all the fruit which will probably be secured must be set within 45 days after the squares begin to form. The advantage of early planted cotton and rapid maturing rarieties becomes, therefore, rery apparent. 


\title{
PAPERS ON THE COTTON BOLL WEEVIL AND RELATED AND ASSOCIATED INSECTS.
}

\section{NOTES ON THE BIOLOGY OF CERTAIN WEEVILS RELATED TO THE COTTON BOLL WEEVIL.}

\author{
By W. Dwight Pierce, \\ Special Field Agent.
}

\section{INTRODUCTION.}

During the year 1905 considerable knowledge was gained concerning the biology of Texas weevils. The practical importance of this information lies in the possibility that from some of these species parasites may be artificially induced to transfer their activities to the boll weevil (Anthonomus grandis Boh.). But it has a further interest in that it makes possible a comparison between the life history of this important enemy of cotton and that of related insects which normally inhabit regions into which that pest has only recently made its advent.

Anthonomus grandis breeds during the entire growing season, from April to October, and on one plant-cotton. Its host plant is so plentiful that there is a constant food supply. Anthonomus signatus Say, which breeds in immense numbers in the flowers of strawberry, blackberry, dewberry, and redbud, is not known to have more than the short period of activity limited by the fruiting of its host plants. Hence the possibility of transferring parasites would be limited to a short period and there would be further difficulties on account of the local distribution of the food plants. Anthonomus reneotinctus Champ., which has been found to breed in enormous numbers in pepper, in western Texas, is not known to occur on other food plants in the spring and early summer, inasmuch as only a part of its cycle of life has been determined.

These three species are the most important of the Texas economic Anthonomi, and from the two latter little may be expected in assisting in the control of the boll weevil, altho it may be important to suggest 
that the parasites of Anthonomus signatus might attack Anthonomus renetinctus if the strawberry and pepper were grown side by side. The former weeril has long been established and has numerous parasites. The latter has not been here long and has not extended its foothold greatly, neither has it many parasites. Both of these species are small, and perhaps not likely to yield parasites which would attack larger species.

Of the large species equaling the boll weeril in size some may, perhaps, yield farorable results. Anthonomus fulvus Lec. gives promise in one way because it breeds in the buds of Callirrhoe involucrata, a mallow closely related to cotton. But this plant ceases flowering early in July, which would make transfer of parasites difficult. The biology of this species is extremely like that of the boll weeril, and it would appear to be easier for parasites to change from it to its more injurious relative than from the two species mentioned before. Anthonomus squamosus Lec., which breeds along the western edge of the cotton belt in the flowers of Grindelia squarrosa nuda, is much more abundantly parasitized than 1 . fulvus has proven to be. Its food plant has a long season, so that several generations are produced. Both of these species seal the egg puncture and pupate in a cell formed by the larval excrement, just as does the boll weeril. Both are parasitized likewise by Bracon mellitor Say, a parasite of Anthonomus grandis. Eurytoma tylodermatis Ashm., listed as a parasite of Anthonomus grandis, is a primary parasite of Lixus musculus Say and probably also of Anthonomus squamosus. Another species of Eurytoma was definitely bred from A. squamosus. Anthonomus scutellaris Lec. is known to breed in wild plums in Texas. Desmoris scapalis Lec., a weevil very similar in habits to the ooll weevil, breeds in the flower heads of Sideranthus rubiginosus, thus resembling $A$. squamosus, but differing from the Anthonomi mentioned, in that it undoubtedly pupates in the ground. This species is very abundant in the heart of the weeril-infested area of the cotton belt and occurs thruout a considerable part of the summer. Moreover, it is often parasitized.

Of the smaller species those to be noticed are not smaller than the smallest of A. grandis and A. squamosus. Anthonomus disjunctus Lec., like the latter, breeds in the flower heads of Heterotheca subaxillaris, a common composite thruout central Texas. It is very numerous and considerably parasitized. Anthonomus æneolus Dietz breeds abundantly in the buds of Solanum rostratum, which occurs thruout Texas. Catolaccus incertus has been bred as a parasite.

The nature of the problem being thus set forth, it will be readily understood that the primary requisite is a knowledge of the breeding habits of as many species of weevils as possible. 
The following notes bear upon the biology of certain of the Texas weevils. The determinations are by Messrs. E. A. Schwarz, W. H. Ashmead, and J. C. Crawford, in those groups respectively in which they are specialists.

\section{ANTHONOMUS DISJUNCTUS Lec.}

This species was found breeding in large numbers on Heterotheca subaxillaris at. Jacksonville, Tex., by Mr. C. R. Jones and the writer. It oviposits in the bud at the base thru the involucre. The presence of the weevil is indicated by the blackening of the two or three involucral bracts which were punctured. The larva feeds among the seed in the seed-head, and forms a compact cell of its exuviæ. Here it pupates and the adult emerges from the dried head.

PARASITES.

Three pteromalids were bred from a few buds brought in to the laboratory.

\section{ANTHONOMUS FULVUS Lec.}

Mr. W. W. Yothers has carried out an extensive series of notes on the biology of Anthonomus fulvus incident to his finding the host plant of this species. On June 9 the first weevils were taken, and found to be very abundant on the flowers of the purple mallow, Callirrhoe involucrata. This was, then, the weevil that had been sought so long - a native insect infesting a close relative of the cotton, and with life history parallel in all details to that of the boll weevil. The questions at once arose as to whether the new weevil was held in check by parasites which might be transferred to the boll weevil, whether it had more than one host plant, whether it would feed on cotton, and whether the boll weevil would feed on the mallow.

The work of the season of 1905 answered some of these questions, but not the one of primary interest. Only one parasite was bred, viz, Bracon mellitor, already known as a primary parasite of Anthonomus grandis. If this parasite was not originally parasitic on $A$. grandis and was so on $A$. fulvus we may reasonably expect that any other primary parasite of the latter may be induced to transfer its energies against the former.

The host plant, Callirrhoe involucrata, is largely diśtributed over the Mississippi River basin, and its guest, Anthonomus fulvus, is known by previous record to occur in Kansas and by observations of this laboratory to breed at Ardmore, Ind. T. (C. R. Jones, collector), and Dallas and Victoria, Tex. Thus it is highly probable that the weevil's range is at least coextensive with the range of this host plant.

The plant is a spring bloomer, thriving in May and June in Texas and gradually later toward the north. According to the laboratory 
records, the weevil's activity is probably limited to the flowering activity of the plant, after which it goes into estivation and hibernation.

The weevil generally oviposits in the bud, altho perhaps also in the ovary. The egg puncture is immediately sealed, just as by Anthonomus grandis. Owing to the brief period from bud to flower the metamorphosis is comparatively rapid. The only observation on this point limited the pupa stage to less than 4 days. The egg is lemonyellow, elliptical, measuring $0.375 \mathrm{~mm}$. in breadth and $0.484 \mathrm{~mm}$. in length. It is placed among the anthers, generally near the base of the floral column. Incident to the act of oviposition the petals become sealed by the released juices and are prevented from fully opening, so that the developing weevil is still protected from its enemies. Larvæ or pupæ are often found thus in the sealed flower, and are sometimes still in this part after it has dropt. On the other hand the larvæ frequently eat into the ovary and there construct a pupal cell of their excrement. The weevils may oviposit in the ovary, altho no definite record was obtained. The ovaries are largely infested by a very small weevil, which is as yet undetermined. After June 9 neither copulation nor oviposition was observed.

July 4 was the last date of finding larvæ in the field. Thirty-two flowers had but two larvæ, and two showed feeding punctures. On July 1 seven adults were taken in the field. The Callirrhoe ceased blooming about July 10. As the weevils in the breeding cages ceased to feed on the flower's early in July, they were placed with a plant in a large breeding cage for estivation on July 27. The Callirrhoe plants were induced to bloom until about November 1 by transplanting, but the weevils did not seem inclined to feed again. A weevil which had not fed for a month was still active August 9, and on August 16 was observed to feed on the flowers of the host plant.

The weevils normally feed on the anthers and on the surface of the petals. They refused to touch the foliage. When offered a choice of Callirrhoe or cotton blooms, they almost invariably went directly to the former. When given cotton alone they were observed to feed on the pollen and petals and in one case indication of feeding on the square was observed.

In habit the weevil is like Anthonomus grandis. It is susceptible to movement and when conscious of a disturbance remains alert on the edge of a petal. A slight movement will cause it to drop to the ground, where it is almost impossible to find it. It is a very ready flyer and goes from plant to plant in this manner.

\section{ANTHONOMUS SQUAMOSUS Lec.}

This species was found breeding in very large numbers by Mr. C. R. Jones and the writer on Grindelia squarrosa nuda at Clarendon, Tex. It has previously been recorded from the same plant in Colorado and 


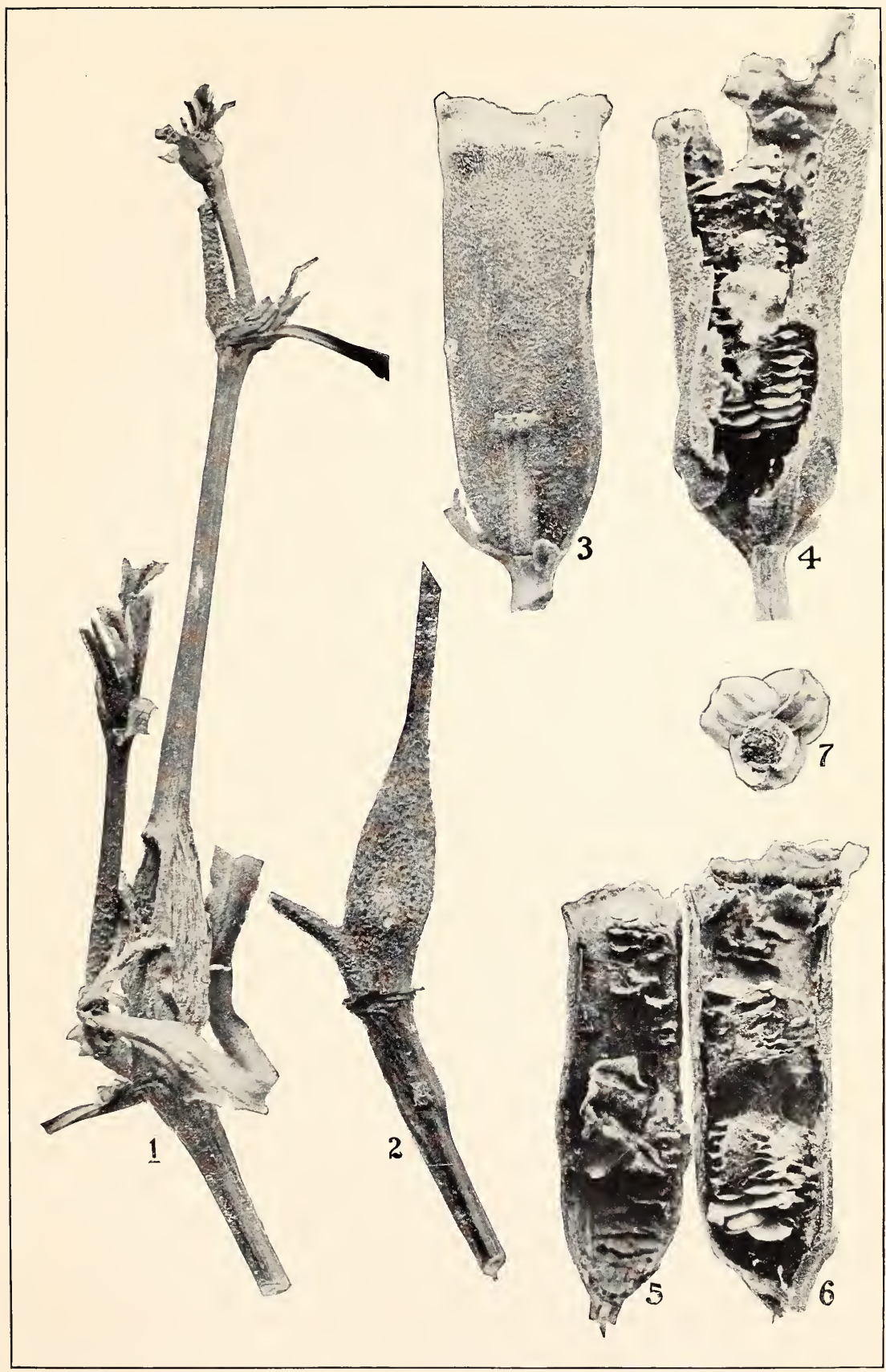

WORK OF LIXUS MUSCULUS AND ORTHORIS CROTCHII.

Fig. 1.-Gall of Lixus musculus and exit hole of adult on stem of Polygonum permsylvanicum. Fig. 2.-Gall of Lixus musculus and entrance hole (closed) of pyralid caterpillar on stem of Polygonum. Fig. 3.-Pod of Mentzelia muda, showing two egg punctures of Orthoris crotchii. Fig. 4-Pod of Nentzelia opened, showing a cluster of Orthoris crotchii cells, and the cocoons of Tetrastichus. Figs. 5, o.-Interior of pod of same, showing several cells of Oithmis crotchii. Fig. 7. $-\mathrm{An}$ isolated cell of Orthoris crotchii, showing the manner in which the seeds are eaten. (Original.) 

what was supposedly the same species from Helianthus in Kansas. It oviposits in the bud or flower at the base thru the involucre. The presence of the weevil is indicated by the blackening of the two or three punctured involucral bracts. The larva feeds among the ovaries in the flower head and forms a compact cell from its exuviæ. This cell is the more compact because of the sticky nature of the flower. Here it pupates and matures, the adult emerging from the dry seed head. The specimens secured differ greatly in size, color, and vestiture.

\section{PARASITES.}

Bracon mellitor Say was bred in large numbers from the larvæ.

Eurytoma tylodermatis Ashm. was bred in large numbers as a primary parasite.

Catolaccus sp. One specimen of this genus was bred, and is presumably a primary parasite.

An undetermined noctuid caterpillar, which eats out the heads of the Grindelia, destroys all weevils breeding in the flowers it attacks.

\section{LIXUS MUScULUS Say. (Pl. I, figs. 1, 2.)}

This species was found by Mr. C. R. Jones and the writer breeding in considerable numbers in the stems of Polygonum pennsylvanicum at Clarendon, Tex. It oviposits near the joints of the stem, and the young larva as it feeds causes the stem to enlarge and form a gall-like cell. These galls are twice the diameter of the stem and about threequarters of an inch long. The growing weevil fits its cell tightly, and consequently, after maturing, it takes some time for it to gain an exit. The adultognaws a round hole in front of its head and then gradually forces itself out.

\section{PARASITES.}

Glyptomorpha (Bracon) rugator Say. One adult was bred from the weevil and numerous pupæ were found in the cells. The pupa is inclosed in a brown papery cocoon, which completely fills the cell and crowds the remains of the Lixus against the wall.

Eurytoma tylodermatis Ashm. was bred as a primary parasite.

Neocatolaccus tylodermæ Ashm. was bred as a primary parasite. This species has been bred also from boll-weevil-infested squares.

Cerambycobius cyaneiceps Ashm. One specimen was bred from an infested stem, and is probably a Lixus parasite.

Eurytoma tylodermatis Ashm. One individual bred from an infested stem and probably a parasite of Lixus, tho perhaps hyperparasitic.

A pyralid larva which dwells in the stems of this plant seems to be very fond of this weevil, as it not only eats those which lie in its path but has been frequently seen to cut a hole into the galls from the outside 
and to feed on the inmate. It makes no choice of the stage of the weevil to be eaten: larvæ, pupæ, and adults have been found partly devoured.

\section{ORTHORIS CROTCHII Lec. (Pl. I, figs. $3-7$.)}

This species was found by Mr. C. R. Jones and the writer breeding in Mentzelia nuda at Clarendon, Tex. It oriposits in the ripening seed pods, and the larva makes its cell in the center of six or seren of the flat transverse seeds. Very often four or five weeril cells will lie side by side, occupying a large part of the interior of the pod. The cells are made up of the exuvia of the larve. Exit is secured thru the open apex of the ripe pod.

\section{PARASITES.}

Microbracon (Bracon) nuperus Cress. was bred in very large numbers as a primary parasite. 'The air around the Mentzelia bushes was thick with individuals of this and the next species. Sereral definite records of hyperparasitism by Tetrastichus were obtained. The latter construct beautiful little white cocoons, and several feed on one host.

Tetrastichus sp. A rery large number of these specimens were bred from the Mentzelia pods, and several very definite cases of primary parasitism were recorded. 


\section{PAPERS ON THE COTTON BOLL WEEVIL AND RELATED AND ASSOCLATED INSECTS.}

\section{AN ANT ENEMY OF THE COTTON BOLL WEEVIL.}

(Solenopsis geminata Fab. var. xyloni McC.)

By W. E. Hinds,

In Charge of Cotton Boll. Weevil Laboratory.

\section{INTRODUCTION.}

That native species of ants are the most important predatory enemies of the boll weevil is an admitted fact, but the real extent of their beneficial work has probably been underestimated rather than overestimated. Several species have been found attacking the weevil in some of its stages, but by far the most important one as yet observed is a rather small species determined by Dr. W. M. Wheeler as Solenopsis geminata Fab. var. xyloni McC. This ant is quite variable in size and color, and the different forms found in Texas have been separated into several varieties. As it is probable that the food habits are similar in each of these forms, the varietal distinctions need not be emphasized here.

Doctor Wheeler has kindly furnished the following information:

The species is common everywhere in the warmer parts of the world, and is both highly carnivorous and highly vegetarian; that is, it will prey on any defenseless or moribund insects, and stores seeds in the chambers of its nest. It stings very severely, whence the name "fire-ant" or "Hormiga brava," which is given it in Spanish America. The dark variety you sent is common in the black soil, such as one finds in cotton fields. I have seen. it in great abundance in the vicinity of Austin, Tex.

\section{DESCRIPTION. $a$}

For the present purpose this ant may be characterized as follows:

There are two distinct nodes or scales in the slender petiole of the abdomen. All forms but the male have a sting. The antennæ are ten-segmented; the club is formed of the last two segments, of which the terminal one is the longer. Maxillary and labial palpi have each two segments. The clypeus has two longitudinal ridges and the sting is very large. The color varies, but the workers usually seen are of a dark reddish brown, the color of the abdomen being often considerably darker than that of the head and thorax. Length of workers from 2 to $3 \mathrm{~mm}$.

$a$ For illustration of the species see Bul. 51, Bur. Ent., U. S. Dept. Agric., fig. 8, p. 149 . 


\section{AN ENEMY OF THE COTTON LEAF-WORM AND BOLLWORIM.}

This species has long been known as an important enemy of the cotton leaf-worm (Alabama argillacea Hbn.). what is probably the first notice of its good service in this connection having been published in 18ti. Since that time so many observers have reported it as attacking the eggs, larræ, and pupæ of the leaf-worm that there can be no doubt of the substantial accuracy of the conclusion that it is one of the most important predaceous enemies of that cotton pest.

While less study has naturally been given to the relationship of ants to the cotton bollworm than to the leaf-worm, it has been shown repeatedly that the species under consideration preys upon both the eggs and larre of the bollworm in much the same way as it does with the leaf-worm.

\section{ITS WORK AS AN ENEMY OF THE COTTON BOLL WEEVIL.}

Considering the important place that these ants hold among the natural foes of the two cotton pests of most serious importance before the advent of the Mexican cotton boll weevil, it is not at all surprizing to find it filling a high place as an enemy of the weeril. For sereral years it has been known that ants frequently attack the immature stages of the weevil in both squares and bolls, but observations made during the season of 190 s have shown that this native ant may be-at least under farorable conditions-a more important factor in the destruction of the weevil than has hitherto been supposed.

During the experiment which was being made to test the effect of direct sunshine in destroying immature stages of the weeril, 150 squares were selected, each of which was believed to contain some stage of the insect. These squares were divided into two lots of $i 5$ squares each and placed upon the bare ground in an exposed spot in the cotton plat at the laboratory in Dallas, Tex. One lot was left dry, while the other was thoroly wetted to determine whether the mortality would be as great in exposed squares which were kept moist. The squares were placed on the ground at $4.30 \mathrm{p}$. m., September 5 . The following morning, while again wetting the lot which was to be kept moist, numerous ants were noticed running around and orer the squares, tho no sign of a nest had been seen near that spot on the previous evening. A hasty examination showed, in sereral squares, holes (fig. $7, b, c$ ) which in size and external appearance resembled weevil emergence holes (fig. $7, a$ ) so closely that at first they were mistaken for them, and it was feared that the stages of the weevil in the squares were too nearly mature to serve as suitable material for the experiment intended. A more careful examination, howerer, showed that the weerils were not emerging, but that the holes in the squares were really entrance holes made by the ants to enable them to get at the immature weerils within. As it was erident that nearly all of the squares had been opened, the experiment intended was abandoned and a complete examination made of all the squares. 
It was soon found that the ant-made holes could, from internal conditions if not from external appearances, be distinguished positively from those made by the weevil, and it was also possible to tell with considerable certainty whether the victim was in the larval or the pupal stage, tho in only a few cases had the ants left any remains of their prey. A careful examination of the interior of a square from which a weevil has emerged shows invariably a small quantity of fine débris removed by the weevil from the wall of the square in cutting its way out. Besides this, there is a small amount of white excrementitious material, the final product of the transformation, which is voided by the weevil before it leaves its cell.

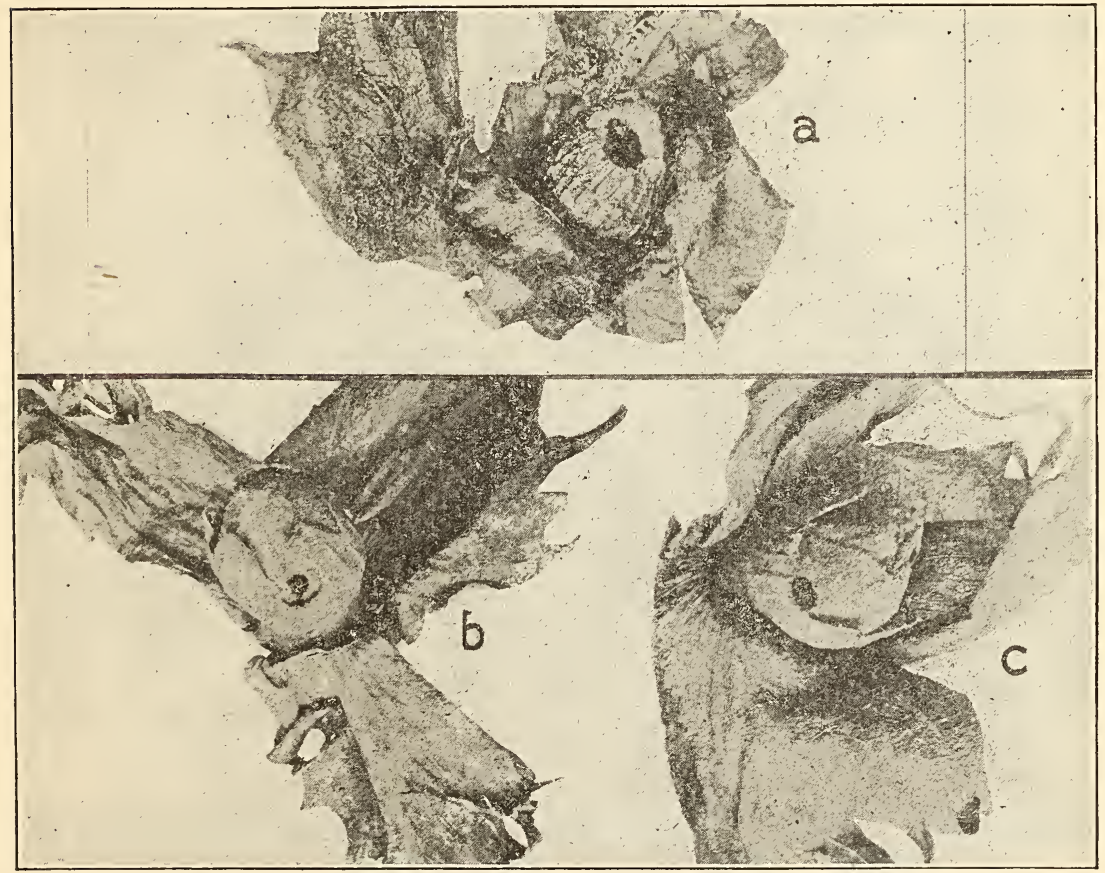

FIG. 7.-An ant enemy of the cotton boll weevil: $a$, cotton square showing emergence hole of boll weevil; $b, c$, cotton squares showing entrance holes of Solenopsis geminata var. xyloni. Slightly enlarged (original).

In cases where the squares had been entered by ants and an immature stage destroyed, neither of these signs of adult weevil activity could be found, but the stage of the weevil could in most cases be told from the presence or absence of the larval exuviæ, which are generally untouched by the ants.

In the lot of 75 squares kept dry it was found that the ants had entered 64, destroying 44 stages which were probably larvæ and 20 which were probably pupæ. Eleven squares showed no ant holes. Of these, 7 contained no weevil stage, 3 contained live, unharmed larvæ of a parasite of the weevil (Bracon mellitor Say) and the 
remains of the weevil larra destroyed by them, and 1 a dead, moldy weeril larra.

In the lot of 75 squares kept wet the ants had entered 73 , destroying 50 stages which probably were larvæ and 23 probably pupæ. The 2 squares not entered by the ants had contained no stages of the weevil. No signs of parasite destruction could be found in this lot of wet squares.

A brief summary of the examination of these 150 squares shows that 9 of them did not contain any stage of the weeril. Not one of the uninfested squares nor, apparently, any one of those containing a parasitized or dead larra was opened by the ants. Among the 137 squares opened by the ants not a single weevil stage escaped destruction, tho the squares had been on the ground but eighteen hours.

The unquestionable connection of these ants with the rapid and complete destruction of erery living weevil stage in 150 squares shows their possible efficacr in the field under conditions which faror their work. The ants were not exceptionally abundant where the foregoing demonstration occurred. The nearest nest was under a cotton plant about 3 feet from the bare spot where the squares were exposed.

On September 25 an examination was made of 300 fallen squares and small bolls collected at random from the ground in this plat. It was found that at that time the ants had destroyed $t 0$ per cent of all weeril stages infesting those squares and bolls. October 6 , in an examination of 212 fallen squares and small bolls, it was found that the ants had destrored 35 per cent of the weeril stages. Obserrations made after Norember 1 indicated that the ants had then practically ceased their activity, only about 10 per cent of the weeril stages haring been destroyed. The ants appear to be unable to enter the square or small boll until after decar has softened and weakened the resistance of the walls inclosing the weeril.

\section{DISTRIBUTION.}

These ants nest in the cotton fields and appear to be distributed orer most if not all of the cotton belt. Their activity is far greater during hot dry weather than during cold wet weather: and this fact may account in some measure for the effect which wet weather is said to have in greatly increasing the numbers and destructireness of the insect pests of cotton. ${ }^{a}$

During the past season Solenopsis geminata rar. xyloni has been taken from infested cotton fields in many localities in Texas and western Louisiana. It seems to be perfectly at home in rarious trpes of soil, and is undoubtedly of considerable benefit as an established enemy of the weevil in practically all of the area now infested. 


\title{
PAPERS ON THE COTTON BOLL WEEVIL AND RELATED AND ASSOCIATEI) INSECTS.
}

\section{A PREDATORY BUG REPORTED AS AN ENEMY OF THE COTTON BOLL WEEVIL.}

\author{
(Apiomerus spissipes Say.) ${ }^{a}$ \\ By A. C. Morgan, \\ Special Field Agent.
}

\section{INTRODUCTION.}

On May 3, 1905, the writer was sent to Gurley, Tex., to investigate the finding, by Mr. Sam. Allen, of that place, of a bug which he reported as an enemy to the Mexican cotton boll weevil (Anthonomus grandis Boh.). Mr. Allen had collected only one specimen, a nymph of Apiomerus spissipes Say. It was taken to Dallas, Tex., where it soon molted and became adult. Other adults were afterwards placed under observation at Dallas in order that the life history and habits of the species might be studied to determine to what extent it was an enemy of the boll weevil, and whether or not it is likely to become of economic importance.

Credit is due Mr. W. W. Yothers for valuable notes upon the life history of this species, especially as regards its food habits.

\section{LIFE HISTORY.}

Copulation.-May 23, 1905, a pair was observed in copulation in the field for over 6 hours at Gurley. Later, at Dallas, a pair was in copulation for 4 hours, and another pair for 3 hours. During the process the female assumes the normal position while the male clings to one side of her, holding on with the fore and hind legs.

Oviposition.-The eggs are laid in masses (fig. 8, b) of 40 to 60 , tho as few as 10 were recorded in one instance and 23 in another. Individual records are as follows: $37,41,49,54$, and 64 . The usual place for oviposition is the underside of a leaf, near the top of the plant. Egg masses have been collected in this position from Ambrosia sp. and Helianthus sp. The eggs are placed so close to each other, side by side, that in the center of the mass, instead of being cylindrical, they are usually more or less hexagonal.

The egg.-The egg (fig. 9) is cylindrical, finely punctured, and varies in color from a bright yellow when first deposited to a light brown 
just before hatching. The collar is shining white. The dimensions of the egg are as follows: Width at narrowest part-just

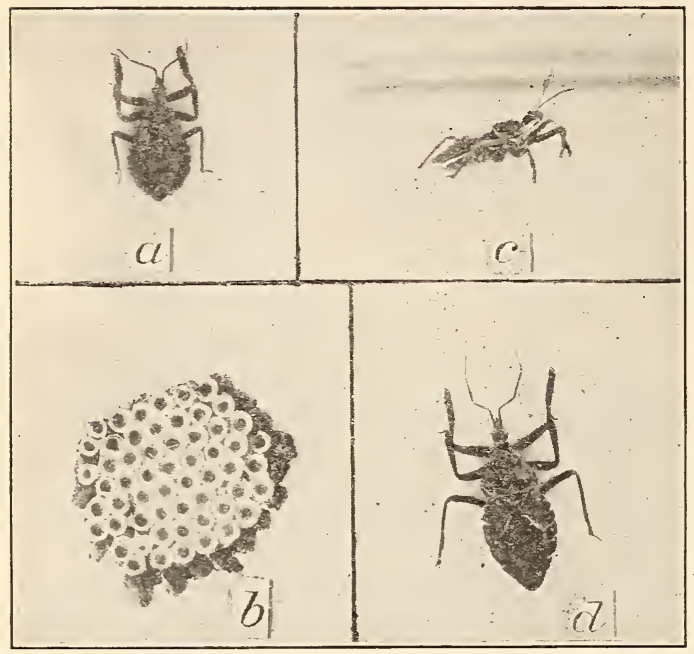

FIG. 8.-Apiomerus spissipes: $a$, nymph, 5 th instar; $b$, egg mass; $c$, adult, side view; $d$, same from above. $a, c, d$, natural size; $b$, enlarged (original).

below collar- $0.5 \mathrm{~mm}$.; greatest width, 0.64 $\mathrm{mm}$.; length below collar, $1.51 \mathrm{~mm}$.; length of collar, $0.26 \mathrm{~mm}$; total length, $1.77 \mathrm{~mm}$. The wid th of the collar varies from slightly less than the greatest width of the egg to slightly more.

Incubation.-Incubation varies slightly in the time required in different egg masses. Thus, in May, under conditions exactly the same, incubation required 12 days in one instance and 16 in another. During midsummer 10 to 12 days were sufficient. Later, in the fall, 14 to 16 days were required.

\section{FOOD.}

The insects preyed upon in the laboratory embraced the orders Orthoptera, Hemiptera, Lepidoptera, Diptera, and Hymenoptera. The process of feeding is a long one and varies with the size of the prey. In general the reduviids lie in wait in an alert attitude for the approach of an insect and then spring upon it, but frequently they take the initiative and fly or run toward an insect. The insect fed upon is not left until all the juices are sucked from its body. Sometimes this takes only a half hour, at other times the reduviid feeds for one or two hours. Boll weevils fed upon by Apiomerus spissipes are often as dry and crush almost as easily between the fingers as do pinned specimens. The first puncture by the beak of spissipes is gen-

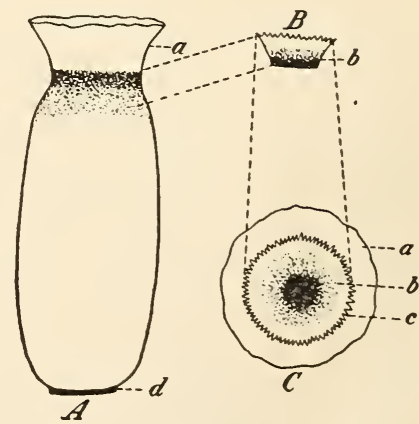

FIG. 9.-Egg of $A$ piomerus spissipes: $A$, side view of egg; $B$, egg-cap, side view; $C$, top view of egg: $a$, collar; $b$, egg cap; $c$, point of junction of egg cap with egg; $d$, attachment of egg to leaf. Much enlarged (original).

erally fatal. In the case of boll weevils, upon which spissipes frequently ied, the weeril made only a few spasmodic movements after 
the first insertion of its captor's beak, and then ceased to move. The power of the bite of this insect was well illustrated upon the writer while collecting specimens. One adult inserted $\mathrm{l}$ is bill in the end of the thumb. The pain at first was not so great as that from the sting of a bee or wasp, but in a few moments it was much greater than the writer had ever experienced from any hymenopteron's sting. It continued unabated for over an hour, and the spot was tender to the touch for two weeks.

Altho locusts, bees, wasps, and an occasional moth were eaten, Coleoptera and Diptera were preferred. The following tables give the food for a number of days of a nymph of Apiomerus spissipes, and, for comparison, the food of another reduviid (Sinea diadema Fab.):

Food of nymph of Apiomerus spissipes in third instar.

\begin{tabular}{|c|c|c|c|c|c|c|c|c|}
\hline \multirow[b]{2}{*}{ Date. } & \multicolumn{4}{|c|}{$\begin{array}{c}\text { Pepper weevils (Anthonomus æneo- } \\
\text { tinctus). }\end{array}$} & \multicolumn{4}{|c|}{ Boll weevils (Anthonomus grandis). } \\
\hline & $\begin{array}{l}\text { Number } \\
\text { added. }\end{array}$ & $\begin{array}{c}\text { Number } \\
\text { killed. }\end{array}$ & $\begin{array}{l}\text { Number } \\
\text { alive } \\
\text { from } \\
\text { previous } \\
\text { day. }\end{array}$ & $\begin{array}{l}\text { Total } \\
\text { number } \\
\text { alive. }\end{array}$ & $\begin{array}{l}\text { Number } \\
\text { added. }\end{array}$ & $\begin{array}{c}\text { Number } \\
\text { killed. }\end{array}$ & $\begin{array}{l}\text { Number } \\
\text { alive } \\
\text { from } \\
\text { previous } \\
\text { day. }\end{array}$ & $\begin{array}{l}\text { Total } \\
\text { number } \\
\text { alive. }\end{array}$ \\
\hline 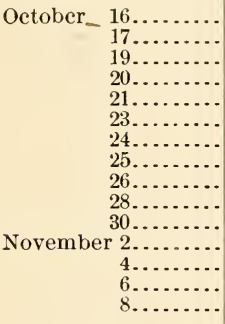 & $\begin{array}{r}3 \\
5 \\
7 \\
5 \\
7 \\
20 \\
0 \\
0 \\
0 \\
5 \\
0 \\
0 \\
0 \\
5 \\
0\end{array}$ & $\begin{array}{r}3 \\
5 \\
5 \\
3 \\
7 \\
11 \\
4 \\
2 \\
3 \\
0 \\
2 \\
1 \\
2 \\
2\end{array}$ & $\begin{array}{l}0 \\
0 \\
2 \\
1 \\
1 \\
9 \\
5 \\
3 \\
0 \\
5 \\
3 \\
2 \\
0 \\
3\end{array}$ & $\begin{array}{r}3 \\
5 \\
7 \\
5 \\
8 \\
21 \\
10 \\
5 \\
3 \\
5 \\
5 \\
3 \\
2 \\
5 \\
3\end{array}$ & $\begin{array}{l}1 \\
0 \\
0 \\
0 \\
0 \\
0 \\
0 \\
0 \\
0 \\
5 \\
0 \\
0 \\
0 \\
0 \\
0\end{array}$ & $\begin{array}{l}0 \\
0 \\
0 \\
0 \\
0 \\
0 \\
0 \\
0 \\
0 \\
0 \\
2 \\
1 \\
0 \\
0 \\
0\end{array}$ & $\begin{array}{l}3 \\
1 \\
1 \\
1 \\
1 \\
1 \\
1 \\
1 \\
1 \\
1 \\
4 \\
3 \\
3 \\
3 \\
3\end{array}$ & $\begin{array}{l}1 \\
1 \\
1 \\
1 \\
1 \\
1 \\
1 \\
1 \\
1 \\
6 \\
4 \\
3 \\
3 \\
3 \\
3\end{array}$ \\
\hline Total... & $\ldots$ & 50 & $\ldots$. & $\ldots$ & ...... & 3 & & \\
\hline
\end{tabular}

The nymph did not feed after November 8. On December 1 it was placed in a cool room for hibernation, but must have died shortly afterwards, for on January 25, 1906, it was found dead and shrunken.

Food of an adult Sinea diadema. ${ }^{a}$

\begin{tabular}{|c|c|c|c|c|c|c|c|c|c|}
\hline \multirow{2}{*}{\multicolumn{2}{|c|}{ Date. }} & \multicolumn{4}{|c|}{$\begin{array}{l}\text { Pepper weevils (Anthonomus æneo- } \\
\text { tinctus). }\end{array}$} & \multicolumn{4}{|c|}{ Boll weevils (Anthonomus grandis). } \\
\hline & & $\begin{array}{l}\text { Number } \\
\text { added. }\end{array}$ & $\begin{array}{c}\text { Number } \\
\text { killed. }\end{array}$ & $\begin{array}{l}\text { Number } \\
\text { alive } \\
\text { from pre- } \\
\text { vious } \\
\text { day. }\end{array}$ & $\begin{array}{l}\text { Total } \\
\text { number } \\
\text { alive. }\end{array}$ & $\begin{array}{l}\text { Number } \\
\text { added. }\end{array}$ & $\begin{array}{l}\text { Number } \\
\text { killed. }\end{array}$ & $\begin{array}{l}\text { Number } \\
\text { alive } \\
\text { from pre- } \\
\text { vious } \\
\text { day. }\end{array}$ & $\begin{array}{l}\text { Total } \\
\text { number } \\
\text { alive. }\end{array}$ \\
\hline \multirow[t]{2}{*}{ Novembe } & 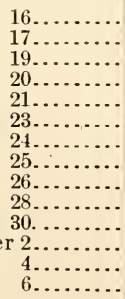 & $\begin{array}{r}3 \\
5 \\
7 \\
5 \\
5 \\
14 \\
9 \\
11 \\
0 \\
5 \\
1 \\
2 \\
0 \\
0\end{array}$ & $\begin{array}{r}3 \\
5 \\
5 \\
2 \\
4 \\
11 \\
12 \\
8 \\
3 \\
1 \\
3 \\
2 \\
2\end{array}$ & $\begin{array}{l}\cdots \\
0 \\
0 \\
2 \\
0 \\
1 \\
4 \\
1 \\
4 \\
1 \\
5 \\
3 \\
3 \\
3\end{array}$ & $\begin{array}{r}3 \\
5 \\
7 \\
7 \\
7 \\
5 \\
15 \\
13 \\
12 \\
5 \\
6 \\
6 \\
6 \\
2 \\
3\end{array}$ & 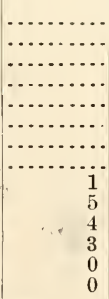 & 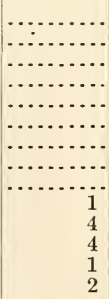 & 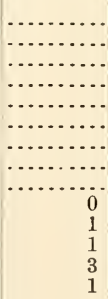 & 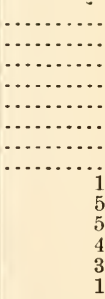 \\
\hline & & ... & 61 & & & .... & 12 & & \\
\hline
\end{tabular}


It should be noted in these tables that while the nymph of Apiomems spissipes killed 50 pepper weerils, and Sinea diadema 61 during the same period, yet spissipes killed only 3 boll weerils. while Sinea killed 12. These results indicate that little benefit can be expected from spissipes in the early stages. The boll reevil is too large for the nymphs to capture easily, hence the choice of the smaller, pepper weerils. It would appear also that a boll weevil diet is not a perfect one, for in the experiments with boll weerils as food for adult spissipes all died in a short time. One adult ate 27 weevils in thirteen dars. but died on the fourteenth day. Other experiments gare similar results. The table shows also that Sinea does not prefer a diet of boll weerils. It ate only 20 per cent as many boll weerils as pepper weerils, altho active enough and strong enough to capture and kill them easily.

An adult Apiomerus spissipes, under observation from June 1 to Juls 3, ate 2 flies, 22 ladybirds. 1 bee, and 1 specimen of the twelrespotted cucumber beetle (Diabrotica 13-punctaia Oliv.). but died on July 6. Another adult, under observation from June 10 to 21. when it died, ate $D$. 12-punctata and a few ladybirds, but refused the potato beetle (Leptinotarsa decemlineata Sas) and its larra and the sharpshooter (Homalodisca triquetra Fab.).

Other adults throre for a time on house flies, but. like those fed upon weerils, thes could not be kept alire. Neither did any combination of the above foods produce any better results.

Food of the young.-The impossibility of keeping the roung alive thru more than two or three instars leads to the conclusion that proper food was not supplied them. On June. 10 sereral specimens of Apiomerus spissipes hatched and were placed in a cage and supplied with cotton aphides (Aphis gossypii Glor.) in abundance. Altho fresh food was supplied daily. spissipes fed rery rarely. and on July 3 the experiment was terminated br the death of the last of the nrmphs. Other experiments with the cotton aphis resulted as in the preceding. October 3 a nymph nearing the third instar was fed upon nrmphs of Pentatoma ligata. It ate 3 nymphs on the $3 \mathrm{~d}$ and 4 th, but died on the 5th. A combination of ligata nymphs and cotton aphides failed to keep another spissipes alive more than a few dars: On September 6, 3 specimens of spissipes which had just hatched were isolated in a jar containing the egg mass from which they came. On September 8 all were dead. This experiment was made to determine whether the egg mass furnishes food for the first instar, as is the case with some pentatomids. From this experiment, and a subsequent one which gave the same results, it is erident that no food is obtained from the egg mass.

The best results were obtained by breaking open heads of Ambrosia in bloom and letting the Apiomerus spissipes nrmphs select food from the insects frequenting this flower. Among the insects found in Ambro- 
sia flowers spissipes fed upon Triphleps insidiosus, a species of the weevil genus Apion, many thrips, and larvæ and pupæ of a cecidomyiid gall-maker.

Cannibalism.-Cannibalism occurs in this species, but is not commonly indulged in. On October 3 three specimens of Apiomerusspissipes that had not fed since hatching were put in each of four pill boxes, without food. The first death occurred October 7, the last Octoher 9. No instances of cannibalism occurred. Other experiments with newly hatched unfed nymphs gave the same result-no cannibalism. October 1 twenty-two specimens hatched and were fed upon insects found in heads of Helianthus. October 7 two nymphs were observed eating a third, and again on October 9, 10, and 12 the same observation was recorded. Other instances must have occurred in the intervals between observations, which would account for the death of individuals not apparently weak or diseased. It is evident, therefore, that the species is cannibalistic, but it is apparent that the first food must be obtained more easily than it could be by a contest with one of its kind of equal age and strength. In nature, however, where each individual goes upon a separate quest for food, it is very unlikely that cannibalism is a serious menace to the species.

\section{LENGTH OF LIFE CYCLE.}

Owing to the abnormal conditions in the laboratory, which made it very difficult to keep either young or old spissipes alive, the length of the instars could not be gaged with certainty. The time between copulation and oviposition varied from 4 to 7 days. Incubation required 10 to 16 days, according to season. The third molt in one instance occurred 12 days after the second, yet specimens have lived more than a month after the second molt without molting. The absences of the writer from the laboratory for a period of weeks at times destroyed the continuity of the experiment, and made it impossible to follow the life history as closely as was desired. However, there can not be more than a fragment of the second generation in a single season. Proper and improper food supply was undoubtedly the cause of the great variation in the length of instars noted above. In nature the same conditions of food supply undoubtedly exist, thus making a difference of months in the maturity of individuals hatched from the same egg mass. Observations in the field bear out this conclusion.

At no time during the year of 1905 could the young be found in any numbers. Altho adults were frequently observed in copulation in June and July at Gurley, later observations failed to disclose more than a few young. It is reasonable to suppose that among the survivors that finally reached maturity some encounter almost perfect con- 
ditions as regards food, while others are barely able to exist, thus lengthening the instars and delaying maturity and greatly increasing the length of the life cycle.

\section{NATURAL ENEMIES.}

Only one natural enemy was recorded during our obserrations upon this species. This was a proctotrypid ege parasite, which Doctor Ashmead pronounced a new species of the genus Hadronotus Först. Only one egg mass was collected from the field. Of these eggs 12 per cent were parasitized.

\section{DISTRIBUTION.}

Say, in describing this species, reports it as being rery abundant in Arkansas. Stål, in his Enumeratio Hemipterorum, reports it from Mexico and Texas. In the Proceedings of the Iowa Academy of Sciences Osborn reports it from Albuquerque, N. Mex. In 1905 it was collected in Texas at San Antonio and Cotulla by J. C. Crawford, at Handley by J. C. Crawford and IV. D. Pierce, at Rosser by C. R. Jones and F. C. Bishopp, and at Gurley and Dallas by the writer. Pittier reports it also from Cruz de Guanacaste, Costa Rica, in Invertebrados de Costa Rica.

\section{CONCLUSION.}

Altho the experiments upon Apiomerus spissipes were conducted in the laboratory under conditions more or less unfarorable to the species, yet enough has been learned of its food habits to class it as a species of doubtful economic value, if not one of positive injury. Also, its scarcity in cotton fields, even tho abundant upon the borders, argues unfarorably. Only occasionally have specimens been observed upon cotton plants, and in the instances when these were observed feeding it was always upon ladybirds. Again, in midsummer, when weerils were most numerous, spissipes could not be found either in the cotton fields or near their border's.

The only injurious insects fed upon were the boll weevil (Anthonomus grandis), the pepper weeril (A. xneotinctus), the twelre-spotted cucumber beetle (Diabrotica 12-punctata), and a few house flies. This was in laboratory experiments. It is doubtful if any of these are fed upon more than occasionally in the field, for not a single instance has been recorded.

Lastly, the great mortality of the young and consequent paucity of adults, the unspecialized food habits, the failure to feed to any appreciable extent upon harmful insects, and the practical disappearance of the species from the ricinity of cultivated fields during a part of the summer would unquestionably place Apiomerus spissipes among insects of economic insignificance. 


\title{
PAPERS ON THE COTTON BOLL WEEVIL AND RELATED AND ASSOCIATED INSECTS.
}

\section{NOTES ON THE PEPPER WEEVIL.}

\author{
(Anthonomus æneotinctus Champ.)
}

By F. C. Pratt, Assistant.

\section{OCCURRENCE IN TEXAS.}

In a previous bulletin" Mr. C. M. Walker gives an account of the pepper weevil, which had been injuring peppers in Texas. Investigation during the fall of 1905 resulted in proving the disappearance of this insect at Boerne, Tex., where it was first reported. Diligent search in October and November by the writer, who was assisted by Mr. L. Lamm, failed to show the existence of the weevils at that place, altho peppers had been grown as extensively as before.

At San Antonio, Tex., many truckers had given up the growing of peppers on account of their experience the year previous, and on one patch at Collins Gardens fully 80 per cent of the pods were attacked, and several bushels of chilli and sweet peppers were shipped from there to Dallas for observation.

Several places, Floresville, Seguin, and New Braunfels, in the vicinity of San Antonio, were visited to ascertain the extent of the infested territory, but without success. Corpus Christi also was visited, but no injury was noticed and no reports were obtained concerning the weevils.

Mr. J. C. Crawford reported the presence of the weevil about 8 miles south of San Antonio, the grower having claimed to have noticed this insect for several years. At Cotulla, Tex., Mr. Henry Caley reported slight injury at one of his truck farms near that place, altho the insect was not seen by the writer.

\section{ORIGIN.}

That this insect (adult, fig. 10) has been introduced into the United States from Mexico in recent years, there is no doubt, the exact date at this time being undeterminable. Inquiries at San Antonio commission houses elicited the information that peppers were shipped from Laredo, Artesia, and Cotulla. As a matter of fact, few peppers are raised at these places, the principal crop being onions. Mr. Caley, at Cotulla, denied ever shipping peppers and was very skeptical about 
any having been shipped from there at any time. Further information showed that peppers were bought up in carload lots in Mexico and

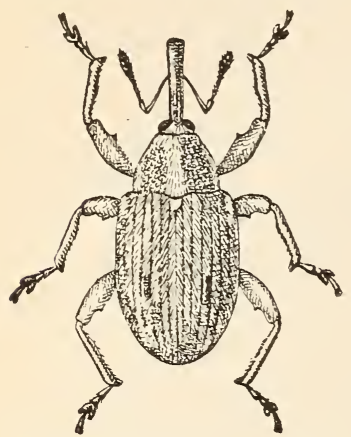

F1G. 10.-Pepper weevil (Anthonomus æneotinctus): Adult. Much enlarged (after Hunter and Hinds).

shipped to the United States and without much doubt rebilled from the localities mentioned to give an impression that these peppers were home grown. Dr. A. W. Morrill reported that a large number of peppers were shipped annually to the United States from the districts of Zacatecas and San Luis Potosi, Mexico, and he had collected the weevil at Tlabualilo, Durango, Mexico.

\section{FOOD PLANTS.}

It is erident that the weevil does not breed in the wild or bird pepper, for these plants were examined thoroly at all the points visited as well as at Victoria, Tex. The bell or sweet pepper (Pl. II, figs. 4-6), chilli (Pl. II, figs. 1-3), and tabasco peppers of several varieties are always affected whererer the weeril occurs.

\section{NATURAL ENEMIES.}

As in the case of the boll weevil (Anthonomus grandis Boh.), altho a few parasites were reared, these did not occur in sufficient numbers to keep the insect in check. Mr. J. C. Crawford has identified the parasitic species as Bracon mellitor Say, and Catolaccus incertus Ashm. A small ant, Solenopsis geminata Fab., ${ }^{a}$ was noticed to be actirely engaged in removing larræ and pupæ from the pods which had weevil exit holes in them, but in no case did the ants make an entrance themselves.

In the parasite breeding cages thousands of small mites were observed by Mr. W. W. Yothers, who reported that their presence in no way incommoded the weerils.

To determine the arerage number of weevils that may infest the chilli peppers, several experiments were tried, with the following results:

\begin{tabular}{|c|c|c|c|}
\hline $\begin{array}{l}\text { Experiment } \\
\text { No. }\end{array}$ & $\begin{array}{l}\text { Number of } \\
\text { pods. }\end{array}$ & $\begin{array}{l}\text { Number of } \\
\text { weevils } \\
\text { emerged. }\end{array}$ & Period covered. \\
\hline $\begin{array}{l}1 \ldots \ldots \ldots \\
2 \ldots \ldots \ldots \\
3 \ldots \ldots \\
4 \ldots \ldots \ldots\end{array}$ & $\begin{array}{r}80 \\
230 \\
200 \\
100\end{array}$ & $\begin{array}{r}86 \\
156 \\
143 \\
123\end{array}$ & \multirow[t]{2}{*}{$\begin{array}{l}\text { Oct. } 18 \text {-Nov. } 4 . \\
\text { Do. } \\
\text { Oct. 18-Nor. } 11 . \\
\text { Oct. 18-Oct. } 31 .\end{array}$} \\
\hline Total... & 610 & 508 & \\
\hline
\end{tabular}

Thus it will be noticed that an average of nearly one adult to each pod was bred.

a See Bul. 63, Pt. III, Bur. Ent.. U. S. Dept. Agric. An Ant Enemy of the Cotton Boll Weevil. By W. E. Hinds. 


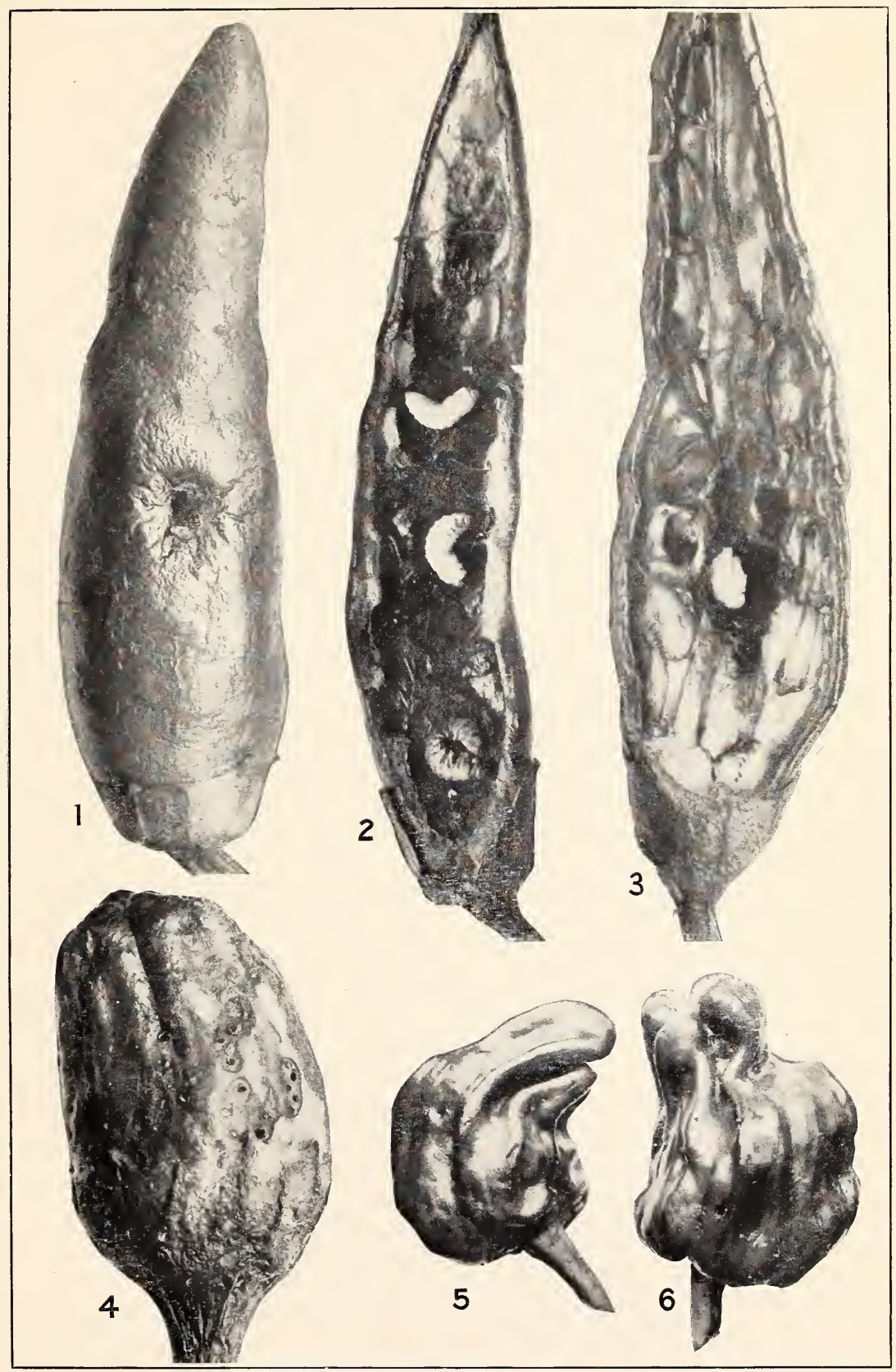

Work of the Pepper Weevil (Anthonomus aneotinctus Champ).

Fig. 1-Emergence holes of adult in chilli pepper. Fig. 2.-Full-grown larva in situ in chilli pepper. Fig. 3.-Pupæ in cells in chilli pepper. Fig. 4.-Undeveloped bell pepper pod, showing numerous egg and feeding punctures. Figs. 5, 6-Malformed bell pepper pods, caused by egg punctures. Figs. 1-3 three times natural size; fig. 4 twice natural size; figs. 5,6 one-lialf natural size. (Original.) 

The maximum numbers of individuals found in two pods were as follows:

\begin{tabular}{|r|r|r|r|r|}
\hline Pod. & Adults. & Pupæ. & Larræ. & Total. \\
\hline & & & \\
\hline $1 \ldots$ & 5 & 2 & 9 \\
\hline $2 \ldots$ & 5 & 6 & 11 \\
\hline
\end{tabular}

Many pods showed six egg punctures, from which five larvæ, in one instance, developed. It was also noticed that in nearly every case where egg insertion was made beyond the middle of the pod the larra was to be found slightly back of the puncture, but where the egg was deposited between the stem and middle of the pod the larva was located immediately underneath. The average number of egg punctures to a pod proved to be about two and one-third.

\section{PROLIFERATION. $a$}

Proliferation was noticed in pods purchased in market at San Antonio, Tex., October 6, 1905, and the following two series of experiments were conducted by Dr. W. E. Hinds and Mr. W. W. Yothers:

Experiments to determine the effects on the pepper weevil of proliferation in the pepper pods.

FIRST SERIES.

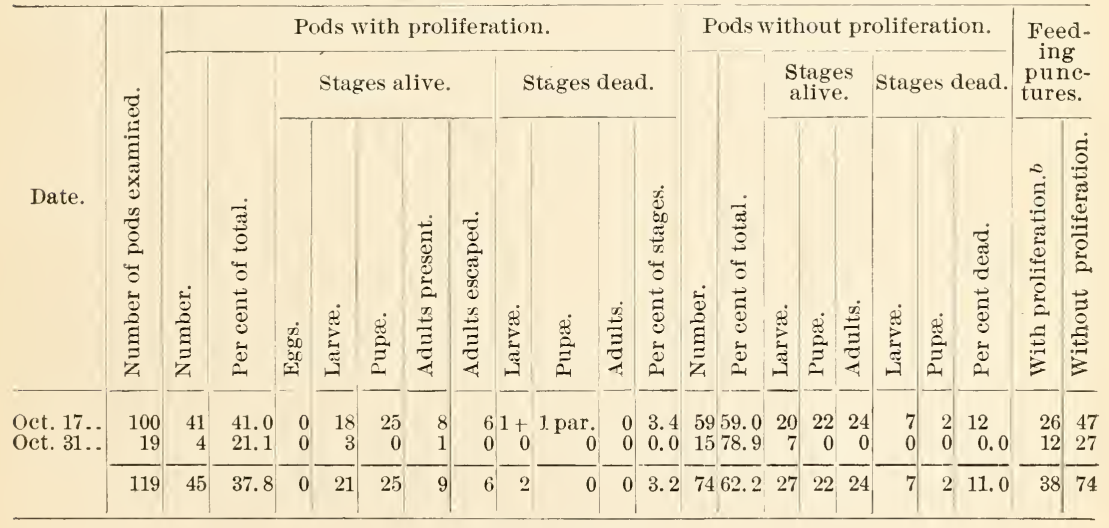

SECOND SERIES.

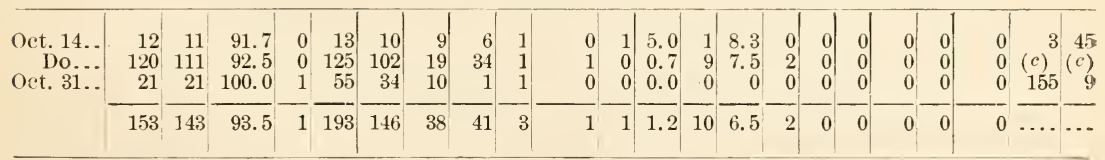

a See also Bul. 59. Bur. Ent., U. S. Dept. Agric., p. 38, 1906.

$b$ This is a record of the proliferated areas on inside of pods and is a minimum.-W. E. H.

$c$ Not recorded.

7036-Bull. $63-09-5$ 


\section{REMEDIES.}

In addition to the usual gathering and destroying of fallen pepper pods, cultural experiments were conducted in the following manner: Some pods were buried in boxes under 1, 2, and 3 inches of soil respectively, keeping one series dry and the other moist-conditions which would result necessarily from irrigation. In the former series the pods dried up and in the latter the pods rotted.

Experiments to determine the effect upon the pepper weevil of covering fallen infested pods with soil.

\begin{tabular}{|c|c|c|c|c|c|c|}
\hline $\begin{array}{l}\text { Num- } \\
\text { ber of } \\
\text { pods. }\end{array}$ & $\begin{array}{l}\text { Number } \\
\text { of punc- } \\
\text { tures. }\end{array}$ & $\begin{array}{l}\text { Depth } \\
\text { of soil. }\end{array}$ & $\begin{array}{l}\text { Condi- } \\
\text { tion of } \\
\text { soil. }\end{array}$ & Period covered. & $\begin{array}{l}\text { Number of } \\
\text { weevils } \\
\text { emerging } \\
\text { Oct.19-Nov.4. }\end{array}$ & $\begin{array}{c}\text { Number of } \\
\text { weevils } \\
\text { found dead } \\
\text { in soil } \\
\text { Nov. } 17 .\end{array}$ \\
\hline 25 & 62 & $\begin{array}{r}\text { Inches. } \\
1\end{array}$ & Wet .... & Oct. 19 -Nov. $14 \ldots$ & 1 adult; 1 & 6 adults. \\
\hline 25 & 61 & 1 & Dry & .... do . & 9 adults..... & 12 adults. \\
\hline 25 & 56 & 2 & Wet & .... do do.......... & 4 adults $a .$. & 1 adult. \\
\hline $\begin{array}{l}25 \\
50\end{array}$ & $\begin{array}{r}60 \\
115\end{array}$ & $\begin{array}{l}2 \\
3\end{array}$ & Dry. & .... do do $\ldots . . . . . . .$. & $\begin{array}{l}3 \text { adults...... } \\
15 \text { adults... }\end{array}$ & $\begin{array}{l}5 \text { adults. } \\
14 \text { adults. }\end{array}$ \\
\hline
\end{tabular}

$a$ Three of these weevils died as soon as they came thru the soil.

Thus it will be readily seen that the covering of the fallen pods every two to three weeks with from 1 to 3 inches of soil would be adrantageous. This could be arranged by bedding high and then lowering the soil. Where irrigation is practised the decay of the pods is greatly hastened, thus depriving the larve of this food supply. It is only fair to state that at the time the pods in these experiments were buried most of the larve were nearly full fed, consequently a larger number came to maturity than would have been the case had burial occurred while the larvæ were small. Two other experiments were conducted by Mr. Wr. W. Yother's in large cages in the open, with the following results:

Experiments to determine the effect upon the pepper weevil of covering fallen infested pods with soil.

\begin{tabular}{|c|c|c|c|c|c|}
\hline $\begin{array}{l}\text { Number } \\
\text { of pods. }\end{array}$ & $\begin{array}{l}\text { Depth of } \\
\text { soil. }\end{array}$ & $\begin{array}{l}\text { Condition } \\
\text { of soil. }\end{array}$ & $\begin{array}{l}\text { Date of } \\
\text { exami- } \\
\text { nation. }\end{array}$ & $\begin{array}{c}\text { Number } \\
\text { of } \\
\text { weevils } \\
\text { emerged. }\end{array}$ & $\begin{array}{c}\text { Number of } \\
\text { weevils dead } \\
\text { in soil Nov. } 15 .\end{array}$ \\
\hline $\begin{array}{l}500 \\
450\end{array}$ & $\begin{array}{r}\text { Inches. } \\
3 \\
2\end{array}$ & $\begin{array}{l}\text { Drya } a . . . \\
\text { Dry } a\end{array}$ & $\begin{array}{ll}\text { Oct. } & 20 \\
\text { Oct. } & 28\end{array}$ & $\begin{array}{l}64 \\
50\end{array}$ & $\begin{array}{l}\text { None found. } \\
\text { Do. }\end{array}$ \\
\hline
\end{tabular}

a Heavy rains October 24 and November 10.

October 31 about 200 of the last-mentioned lot of pods were examined and found to contain 73 living and 9 dead stages; of this number 47 were pupx and 15 were larve. The latter necessarily would have starved, owing to the rapid decay of the buried pods. 


\section{PAPERS ON THE COTTON BOLL IVEEVIL AND RELATED AND ASSOCIATED INSECTS.}

\section{THE STRAWBERRY WEEVIL IN THE SOUTH-CENTRAL STATES IN 1905.}

(Anthonomus signatus Say.)

By A. IV. Morrill,

Special Field Agent.

For some time the Bureau of Entomology has been experimenting along the line of inducing parasites of related native species of weevils to prey upon the cotton boll weevil (Anthonomus grandis Boh.). One of the commonest and most parasitized of such weevils is the strawberry weevil (Anthonomus signatus Say). It was consequently important to ascertain whether this insect occurred in or near the infested regions of Texas and Louisiana and to what extent it was controlled by parasites.

In connection with this work, during the month of April, 1905, advantage was taken of an opportunity to observe the occurrence and injury of the strawberry weevil in the leading strawberry-producing sections of Texas, Louisiana, and Arkansas. Examinations were made in all cases in the blooming season when the insects would, if present, occur in their greatest abundance. In consideration of the destructiveness of this species in the strawberry fields of Maryland and North Carolina during the past few years, the data concerning its occurrence and nonoccurrence in the important strawberry-growing sections of other States are deemed of sufficient importance to be recorded.

\section{THE STRA WBERRY WEEVIL IN TEXAS.}

According to the latest available statistics (1899), ${ }^{a}$ more than fourfifths of the strawberries produced in the State of Texas are grown in two limited areas comprizing three counties. Of these sections the 
one ranking first in importance includes Brazoria and Galveston counties-two adjoining coast counties near the southeastern corner of the State. In this section examinations were made on April 7 and $s$ at Alvin and Galveston, respectirely, but without finding any indications of the presence of the strawberry weevil. The second largest strawberry-growing section of Texas is included in Smith County, near the northeastern corner of the State. An examination was made at Trler, near the center of this section, on April 13, and again on April 28 . On the first of these dates a single adult specimen was taken, and on the second occasion two adult specimens. In a total of about three hours spent near Tyler in fields of strawberries, blackberries, and dewberries, searching for these weerils and for eridence of their work, only the three adults and less than fifty injured buds were found.

The only published record known to the writer of the strawberry weeril's occurrence in 'Texas was by Dr. F. H. Chittenden, ${ }^{a}$ who reported injury by this species, in 1897, to blackberries and dewberries near Denison, in Grayson County, in the north-central section of the State. The fruit farms of the two correspondents who reported serious losses in that year were risited by the writer on April 21, 1905, and examinations made in fields of strawberries, blackberries, and dewberries. One of the owners reported that the weevils had been scarcely noticeable since April, 1897, when they were very destructive and so abundant that on sunshiny days they seemed to fairly swarm on the foliage of the food plants. This encouraging report concerning its scarcity in recent years gives ground for the hope that conditions in northern Texas will as a rule be unfarorable for this pest, altho a certain degree of intermittence in abundance during a series of years has been generally observed in other localities.

\section{THE STRAWBERRY WEEVIL IN LOUISIANA.}

In 1899, as shown by the Census report. ${ }^{b} 90$ per cent of the strawberries produced in this state were grown in Tangipahoa Parish. This parish is located a short distance northwest of New Orleans. Hammond, one of the two leading shipping points in the parish, was risited on April 11. Examinations in strawberry fields and of wild blackberry bushes along the roadsides, in a downpour of rain, resulted in finding no evidence of the presence of the strawberry weeril near this place. As the day was so far from an ideal one for finding adults of this species, the only significant point is the failure to find a single flower bud injured in a manner to cause their presence to be suspected.

" Bul. 10, n. s., Dir. Ent., U. S. Dept. Agric., pp \$2-\$3.

$b$ Twelfth Census of the United States, 1900. 
THE STRAWBERRY WEEVIL IN ARKANSAS.

The strawberry-growing industry in Arkansas is a very important one, in 1899 the production of this State being nearly four times that of Texas and Louisiana combined; or, in round numbers, nearly 13,000,000 quarts. Three sections of the State were visited, including the two leading strawberry-growing districts which together produce more than four-fifths of all the strawberries grown in the State. ${ }^{a}$ The first in importance of these sections comprizes three adjoining counties in the northwest corner of the State-Benton, Washington, and Crawford. Van Buren, located in Crawford County, the southernmost of the three named, was visited on April 27. A single adult specimen of the strawberry weevil was taken on a wild blackberry growing by the roadside, but in the strawberry fields the only indications of its presence which were found were a few scattering severed flower buds. The second section in importance in strawberry production in Arkansas is located in White County, which is situated a short distance northeast of the geographical center of the State. This county in $1899^{a}$-produced one and a half million quarts of strawberries, or a quantity a little short of equaling the total production of the State of Louisiana. Bald Knob and Judsonia, two leading strawberry shipping points in Smith County, were visited on April 25. Many strawberry fields were visited, and the weevil was found to be moderately abundant near these localities. The destruction in the many fields examined was estimated to range from 5 to 25 per cent of the flower buds, averaging between 10 and 15 per cent. Along the roadsides a small percentage of the flower buds of wild blackberries had been wholly or partially severed. The weevil and its destructive habits were found to be fairly well known among the strawberry growers in this section, by whom the weevil was reported to have varied in abundance from year to year, and in occasional years in the past to have accomplished considerable damage. The destruction of the flower buds, as mentioned above, did not necessarily represent a proportionate loss to the growers, as picking had begun about ten days earlier, and berries produced from flowers which set at a later date than the writer's examination very likely would remain unpicked owing to the expected falling off in the market demands. The third locality in Arkansas where an examination was made is near the center of the State, 1 mile from Little Rock. An hour's search in a strawberry field on April 26 revealed a few severed buds, while not a hundred yards away wild blackberries, which were very common along the roadsides, had from 5 to 10 per cent of their flower buds destroyed. The only adult specimen of the strawberry weevil taken in this vicinity was on a blackberry bush. 


\section{VARIETIES OF STRAWBERRIES GROWN.}

At Alvin, Tex., the favorite variety among the strawberry growers is the Klondike, while at the other localities mentioned individual preference seems to be divided between the Lady Thompson, Michel, and Excelsior varieties. In the section of the country to which these notes refer, the writer has never met any strawberry growers who use any but bisexual varieties. Arkansas growers, who probably suffer more or less loss every year from the strawberry weevil, should be encouraged to introduce suitable early pistillate rarieties, as the insect in that State threatens to cause, occasionally at least, considerable destruction. 


\section{PAPERS ON THE COTTON BOLL IVEEYIL AND RELATED AND ASSOCIATED INSECTS.}

\section{THE COTTON STALK-BORER.}

(Ataxia crypta Say.)

By A. C. Morgan,

Special Field Agent.

During October, 1905, while inspecting cotton fields in the vicinity of Yoakum, Tex., the writer's attention was attracted by the great number of dead stalks. Examination showed that these stalks contained larvæ, pupæe, and adults of the cotton stalk-borer (Ataxia crypta Say).

\section{DISTRIBUTION.}

The specimen which Say described in 1832 as Lamia crypta came from Louisiana. Haldeman's specimen, described as $A$. sordida, came from Alabama. Leng and Hamilton recorded the species from Pennsylvania, Alabama, Louisiana, Texas, and New Mexico. In Biologia Centrali-Amiericana its habitat is extended to Almolonga, Mexico. It has been reported to the Department from Tucson, Ariz.; New Orleans, La.; Savannah, Ga.; Grant, Fla.; and Round Mountain, San Diego, Beeville, Bexar, Edgar, Flatonia, and Dallas, Tex. During 1905 the writer found it in Texas at Yoakum. Sublime, Corpus Christi, Cotulla, Alice, and Victoria. During February and March of 1906, Mr. W. W. Yother's collected hibernating adults from cotton bolls at Athens, Brenham, Narasota, and Calvert, Tex., and on Narch 1, 1906, the writer also obtained specimens from bolls at Flatonia, same State.

\section{HOST PLANTS.}

The cotton stalk-borer attacks a number of plants. At 'Tucson, Ariz., it was reported on Helianthus and Xanthium. At Savannah, Ga.; New Orleans, La., and Round Mountain, Tex., larvæ have been found boring in the twigs and trunk of the fig. Mr. E. A. Schwarz informs the writer that it has been bred frequently from the stem of Ambrosia, and one report of the borer in this plant was received by 
the Department from Edgar. Tex. On March 1. 1906, the writer found larre in the stems of Ambrosia and Helianthus at Flatonia. Tex. It has been reported breeding in cotton from Bexar and San Diego. Tex.. and the writer found it in October. 1905, breeding in this plant at Yoakum. Sublime. and Victoria, and in Norember at Alice. Tex. The adult has been reported from peach and apricot. but there are no records to show that it injures either of these plants. Leng and Hamilton state that specimens were found boring in dry twigs of box elder (Acer negundis) and hackberry.

\section{LIFE HISTORY.}

Tery little work has been done upon the life history of this species. The egg is laid upon the host plant and the larra upon hatching bores into the bark or wood of the plant, where it feeds until full grown. pupates, and finally. when adult, cuts its way out. The winter is rery probably past in any of the three stages of larra, pupa, or adult. for it has been reported br Mr. E. A. Schwarz as emerging in Mar, 1597. from a stalk of cotton cut in December. 1596. In October, 1905. the writer found the insect in cotton stalks in all stages of derelopment from the rerr small larra to the adult reads to emerge from the stalk.

In southwest Texas. where the winters are rers mild, it is rers likely that derelopment proceeds slowly all winter long. except in the most serere winters, when it would probably cease for a few weeks.

\section{INJURY AND ECONOMIC IIMPORTANCE.}

Rarels has the cotton stalk-borer been reported. and in no case has serious damage been ascribed to it. Altho it was described by sar as early as 1832, no mention is made of it in economic literature until 1596. and since that time onlr five short notes hare been made. all of which are apparently based upon Dr. L. O. Howard's first published notice in 1596. which read- as follows:

There is but one borer in the stalks of cotton, and that is the long-horned beetle known as Ataxia crypta (Say). It is occasionally mistaken for an enemy of the plant, but investigation has shown that it lars its eggs upon, and its larræ bore into, only such stalks as have been damaged by some other cause, such as rust. It follow: injury to the plant rather than causes it.

The rather general occurrence of this insect at Yoakum. Tex., in 1905 has made it seem adrisable to publish this more extended note. Twenty-six fields were examined in thislocality and showed that from 5 to 10 per cent of the stalk- rere infested by this insect. One field had 20 to 25 per cent of its stalks injured by the horer. It is to he regretted that the discorery of this infested locality was not made earlier in the season, so that a more conclusire studr could have been made. 


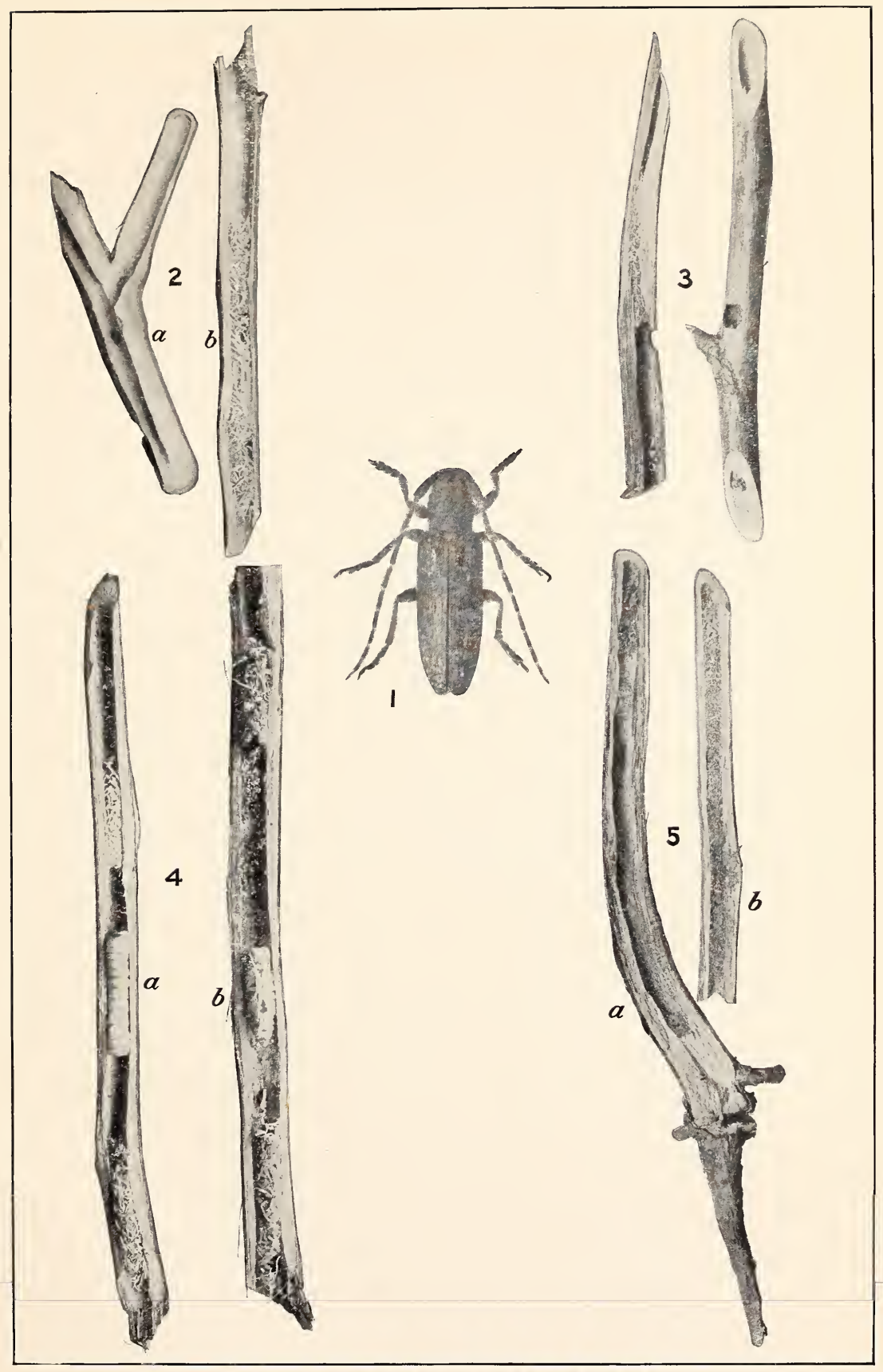

THE COTTON STALK-BORER (ATAXIA CRYPTA).

Fig. 1.-Adult or beelle. Fig. 2.- $a$, Galleries: $b$, work. Fig. 3.-Emergence hoies of adults Fig. 4-a Larva in situ. $b$, castings behind larva. Fig. 1 twice natural size; figs. $2-5$ two-thirds natural size. (Original.) 

As has been stated by Doctor Howard, it is the larva of the borer that works in the cotton stalk. It confines its attack to the pith of the plant. The amount of injury depends upon the size of the plant and the number of borers. The writer found one plant about 3 feet high at Yoakum which contained eight larve. and which showed four emergence holes. The twelve borers had eaten out all the pith from the smallest hranches to 3 inches below the surface of the ground in the tap-root. The small twigs were only thin shells and crumpled like paper between the fingers.

Nearly all infested plants showed unmistakable evidence of previous injury, yet the comparatively fresh and healthy condition of a few stalks points to the probability of an occasional attack upon perfectly healthy stalks. In the field showing an infestation of 20 to 25 per cent of its stalks it was estimated that the injured stalks had borne at least 80 per cent as much cotton to a stalk as had the uninjured ones. If it is true that the borer attacks only such stalks as are diseased or otherwise injured, then only a little damage can be attributed to it; yet the borer's attack, added to the injury due to disease, must hasten the death of the plant and thereby lessen the number of bolls to mature.

\section{NATURAL ENEMIES.}

From material collected at Yoakum, Tex., on October 28 two parasites of Ataxia crypta were bred. One, Heterospilus websteri Ashm., had entirely corered the pupa of $A$. cmpta with its cocoons. In the majority of cases, however, this parasite had spun its cocoon after crawling away from the body of its host. Several masses of these cocoons were found with no trace of either the larva or pupa of $A$. crypta visible, and in one instance the larre of this parasite were found in a hollow cotton stalk and no form of A. crypta near. The second parasite belongs to the genus Etroxys and is a new species. There is some doubt that this species is a parasite upon Ataxia, but since it is parasitic upon beetles and its pupre were found in a stalk bored out by $A$. crypta, it is here placed on record as a parasite of the latter.

\section{REMEDY.}

If at any time the injury by the insect should become serious the number's of the borer can be easily reduced by destroying the infested stalks early in the fall. The time of destruction must, of course, vary in different localities, but it should be as early in October as possible for the latitude of Yoakum. Br October 28 not more than 10 per cent of the borer's had emerged. If the stalks had been destroyed early in October very few borers would have escaped. To obtain the best results, stalks should not be cut but plowed out, for many of the 
borer's go 2 or 3 inches below the surface of the ground in the tap-root and pupate there. In regions infested by the boll weeril, if the farmers would follow the directions giren by this Bureau for the destruction of stalks. the cotton stalk-borer would not appear. In regions uninfested by the boll reeril but infested br the cotton stalkborer, an occasional examination of infested areas for the emergence holes of the borer or an examination of the stages in the stalk- which can be made by splitting the stalk with a knife-will show the planter when to begin plowing and burning.

\section{BIBLIOGRAPHY.}

1832. SAY, Thomas.-Insects of Louisiana, pp. 5 and 6, and Entomology of North America (Le Conte, ed.), rol. 1, p. 302.

Original description under the name of Lamia crypta.

1847. Haldemax, S. S.-Trans. Amer. Phil. Soc., rol. 10, p. 56.

A description of the insect under the name Ataxia sordida.

1878. Schwarz, E. A.-Coleoptera of Florida. <Proc. Am. Phil. Soc., Vol. XVII, p. 457 .

18s3. Le Coxte, J. L., and Hors, G. H.-Classification of Coleoptera of North America, p. 329.

A uthority for present nomenclature.

1585. Bates, H. W.-Biologia Centrali-Americana, vol. 5, p. 347.

A short note upon srnonrmy.

1896. Howard, L. O.-Bul. 33, Office of Experiment Stations, p. $34 \bar{r}$

First economic note.

1896. Lexg, Chas. IV., and HAmltox, Johx.-The Lamiinæ of North America. $<$ Trans. Am. Ent. Soc., Vol. XXIII, p. 143.

1897. Howand, L. O.-Farmers' Bul. No. 47, U. S. Dept. Agric., p. 28.

1899. SAxdersox, E. D.-Cotton Planters' Journal, May, 1899.

1902. SAxdersox, E. D.-Insects Injurious to Staple Crops, pp. 197, 198.

1905. Sindersox, E. D.-Farmer's Bul. Yo. 223, U. S. Dept. Agric., p. 17.

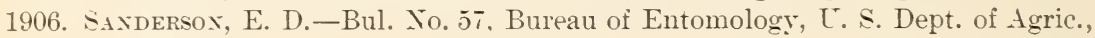
p. 38. 


\section{INDEX.}

Page.

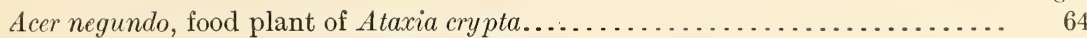

Alabama argillacea. (See Leaf-worm, cotton.)

Ambrosia, food plant of Ataxia crypta......................... 63,64

Ant enemy of boll weevil................................. $45-48$

Anthonomus æneolus, host of Catolaccus incertus..................... . 40

on Solanum rostratum.......................... 40

æneotinctus.................................... . 55-58

enemies.............................. 56-57

food for Apiomerus spissipes ............... 51, 52,54

Sinea diadema ................... 51,52,54

plants............................. 39,56

influence of proliferation. . . . . . . . . . . . 57

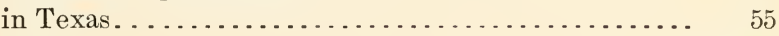

origin................................ $55-56$

remedies. . . . . . . . . . . . . . . . . . . . . . 58

disjunctus, habits.............................. 41

on Heterotheca subaxillaris................... 40,41

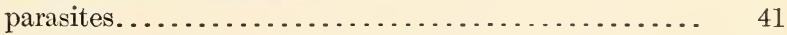

fulvus, habits............................... . 41-42

host of Bracon mellitor..................... 40,41

on Callirrhoe involucrata..................... 40, 41-42

grandis (see also Boll weevil).

as food for A piomerus spissipes............... 51,52,54

Sinea diadema.......................51,52

host of Bracon mellitor...................... 40, 47

Eurytoma tylodermatis.................. 40

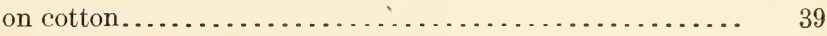

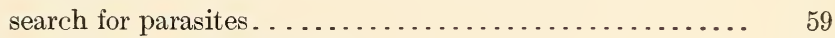

scutellaris, on wild plum in Texas................... 40

signatus, food plants. . . . . . . . . . . . . . . . . . . . 39,60

in Arkansas..................................... 61

Louisiana.................................. 60

South-Central States in $1905 \ldots . . . . . . . . . . . .5 .59-62$

Texas. . . . . . . . . . . . . . . . . . . . . . . . 59-60

squamosus, habits............................... 42-43

host of Bracon mellitor..................... . 40,43

Eurytoma tylodermatis................. 40, 43

on Grindelia squarrosa nuda............... . 40,42-43

parasites............................... 43

Aphis, cotton. (See Aphis gossypii.)

gossypii, not proper food for A piomerus spissipes............... 52

A pionerus spissipes, cannibalism . . . . . . . . . . . . . . . . . . . . . . 53

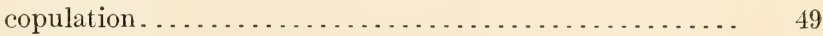

distribution................................. 54

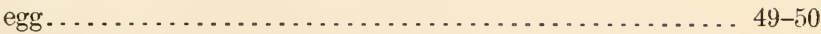


Apiomerus spissipes, enemies....

enemy of boll weevil . . . . . . . . . . . . . . . . . . 49-54

food.................................... $50-53$

incubation................................. 50

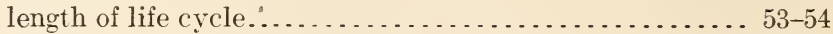

life history .............................. $49-50$

oviposition.................................. 49

Apion, eaten by Apiomerus spissipes. . . . . . . . . . . . . . . . . . . . 53

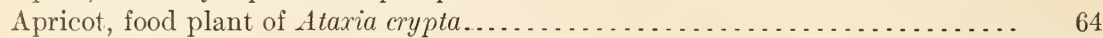

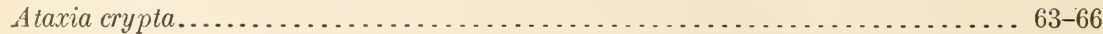

bibliography......................................... 66

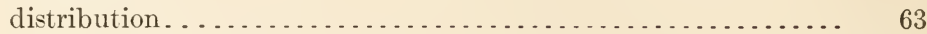

economic importance...........................64-65

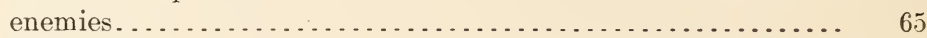

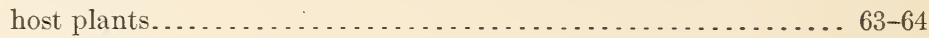

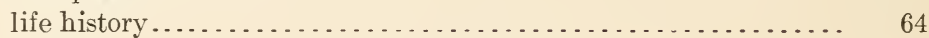

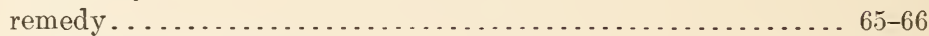

sordida, bibliographic reference........................ 63, 66

Bees, eaten by Apiomerus spissipes.............................. 51,52

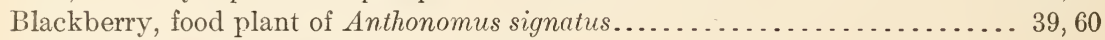

Boll weevil (see also Anthonomus grandis).

ant enemy, Solenopsis geminata xyloni.... . . . . . . . . . . . . . . 45-48

biology of related weevils, notes. . . . . . . . . . . . . . . . . . . 39-44

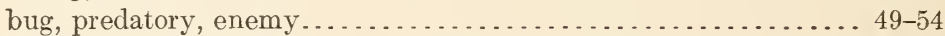

control by crop rotation.................................. 24

early planting, explanation ................... 38

fall destruction of stalks................... $7,22-24$

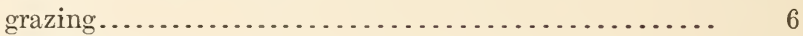

leaf-worm........................ $6-7$

planting early varieties of cotton................ 38

Solenopsis geminata xyloni.................... . 46-48

development of immature stages during normal period of hiberna-

tion......................................... $8-11$

hibernation and development...................... 1-38

as affected by rainfall...................... $5-6,13$

temperature................. $3-6,13$

condition of immature stages ................. 10

emergence, time......................... 19-22

entrance, date........................... 1-5

mortality in cages....................... 2-3

the field. . . . . . . . . . . . . . . . . . . . . . . . . 11-14

time when greatest.................... 14-17

number entering........................... $5-8$

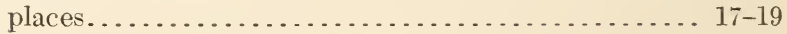

of first appearance after emergence . . . . . . . . . 24 24-25

prevention............................... 22

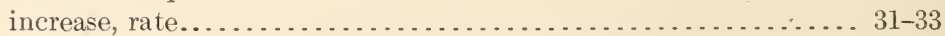

mortality at different stages of development............... 29

during hibernation, in cages.................. $2-3$

the field ................... . 11-14

time when greatest............... 14-17

in buried squares.............................. . . 30

of summer broods............................. 28-31 
Boll weevil, percentage emerging from infested squares . $\quad$ Page.

places of first appearance after emergence from hibernation . . . . . 24-25

preyed upon by Apiomerus spissipes..................... . 49-54

progress of infestation compared with production of cotton fruit. . 33-38

summer broods...................................... 25-31

mortality ............................. 28-31

Bollworm, preyed upon by Solenopsis geminata xyloni................ 46

Box elder. (See Acer negundo.)

Bracon mellitor, parasite of Anthonomus xneotinctus.................... $\quad 56$

fulvus.................... 40,41

grandis...................... 40,47

squamosus.................... 40,43

Bug, predatory, reported enemy of boll weevil. . . . . . . . . . . . . . . . 49-54

Burning of stalks in control of boll weevil......................... 7

Callirrhoe involucrata, food plant of Anthonomus fulvus.............. . 40, 41-42

Cannibalism in Apiomerus spissipes.............................. 53

Catolaccus incertus, parasite of Anthonomus æneolus................... 40

xneotinctus .................... 56

sp., parasite of Anthonomus squamosus..................... 43

Cecidomyiid gall-maker, eaten by Apiomerus spissipes................ 53

Cerambycobius cyaneiceps, parasite of Lixus musculus . . . . . . . . . . . . . 43

Cotton aphis. (See Aphis gossypii.)

boll weevil. (See Boll weevil and Anthonomus grandis.)

early varieties to avoid damage from boll weevil, explanation....... 38

planting to avoid damage from boll-weevil, advantage explained.. 38

fall destruction of stalks in boll-weevil control............. . 7, 22-24

food plant of Anthonómus grandis............................... 39

Ataxia crypta................................. 63, 64

leaf-worm. (See Leaf-worm, cotton.)

squares, injury from boll weevil in relation to natural increase of squares. 33-38 stalk-borer. (See Ataxia crypta.)

varieties, production of fruit ........................... . . . 34-37

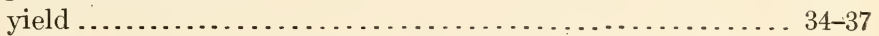

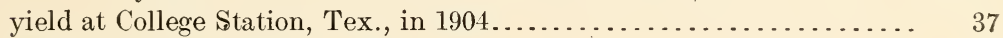

Crop rotation in control of boll weevil......................... 24

Cucumber beetle, twelve-spotted. (See Diabrotica 12-punctata.)

Cultural experiments in control of pepper weevil.................. 58

Desmoris scapalis on Sideranthus rubiginosus........................ $\quad 40$

Development of boll weevil during normal period of hibernation....... . . . . 8 8-11

Dewberry, food plant of Anthonomus signatus.................... 39, 60

Diabrotica 12-punctata, eaten by Apiomerus spissipes.................. 52,54

Etroxys sp., parasite of Ataxia crypta........................... 65

Eurytoma tylodermatis, parasite of Anthonomus grandis................. . 40

squamosus................ 40, 43

Lixus musculus..................... 40, 43

Fall destruction of stalks in control of boll weevil................. 7

Fig, food plant of Ataxia crypta................................ 63

"Fire-ant," name for Solenopsis geminata.......................... 45

Flies, house, eaten by Apiomerus spissipes..................... 52,54

Food supply as controlling numbers of boll weevil in the fall. . . . . . . . . $5-6$

Glyptomorpha rugator, parasite of Lixus musculus................... $\quad 43$

Grazing, factor in control of boll weevil............................ 6

Grindelia squarrosa nuda, food plant of Anthonomus squamosus... . . . . . . . 40, 42-43 
Hackberry, food plant of Ataxia crypta ........

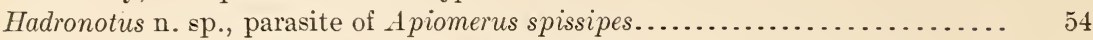

Helianthus, food plant of Anthonomus squamosus.................... 43

Ataxia crypta........................... 63, 64

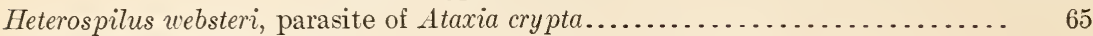

Heterotheca subaxillaris, food plant of Anthonomus disjunctus............. 40,41

Hibernation of boll weevil, as affected by rainfall.................. . 5-6, 13

temperature................ $3-6,13$

condition of immature stages................ 10

development of immature stages during normal

period............................ 8-11

emergence, time........................ 19-22

entrance, date........................ 1-5

mortality in cages.................... 2-3

the field..................... 11-14

time when greatest $\ldots . \ldots \ldots \ldots \ldots \ldots \ldots .14-17$

number entering........................ 5

places............................ 17-19

of first appearance after emergence ...... . 24-25

prevention........................... 22

Hinds, W. E., paper, "An Ant Enemy of the Cotton Boll Weevil (Solenopsis

geminata Fab. var. xyloni McC.)" ............................ $45-48$

Homalodisca triquetra, refused by Apiomerus spissipes................ 52

"Hormiga brava," Spanish-American name for Solenopsis geminata......... 4 .

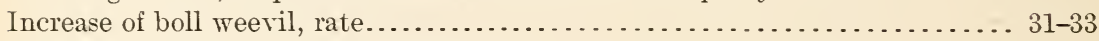

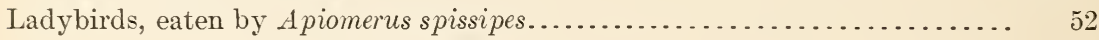

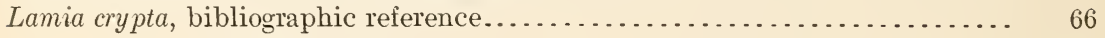

= Ataxia crypta...................................... 63

Leaf-worm, cotton, factor in control of boll weevil.................... $6-7$

preyed upon by Solenopsis geminata xyloni............. 46

Leptinotarsa decemlineata, refused by Apiomerus spissipes............... 52

Lixus musculus, habits.................................... . . . $43-44$

host of Eurytoma tylodermatis.................... 40,43

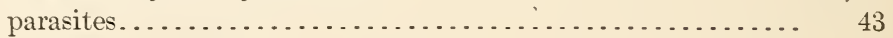

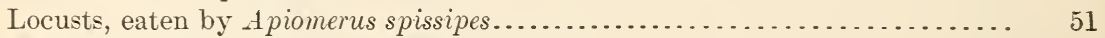

Mentzelia nuda, food plant of Orthoris crotchii........................ 44

Microbracon (Bracon) nuperus, parasite of Orthoris crotchii............... 44

Morgan, A. C., paper, "A Predatory Bug Reported as an Enemy of the Cotton Boll Weevil (Apiomerus spissipes Say)" ... . . . . . . . 4 49-54

"The Cotton Stalk-Borer (Ataxia crypta Say)"......... 63-66

Morrill, A. W., paper, "The Strawberry Weevil in the South-Central States in

1905 (Anthonomus signatus Say)" ............................ . . 59-62

Mortality of boll weevil at different stages of development................ 29

hibernating in cages.................... $2-3$

the field..................... 11-14

in buried squares......................... 30

summer broods ............................. $28-31$

time when greatest during hibernation ........... 1t-17

Neocatolaccus tyloderma, parasite of Lixus musculus . . . . . . . . . . . . . . . . 43

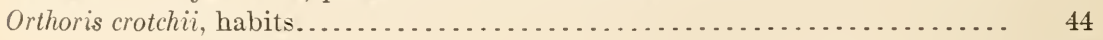

parasites...................................... 44

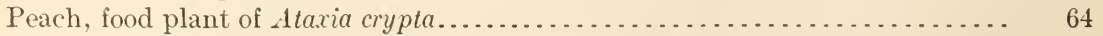

Pentatoma ligata, not proper food for A piomerus spissipes.............. $\quad 52$ 
Pepper, bell or sweet, chilli, and tabasco varieties, food plants of Anthonomus

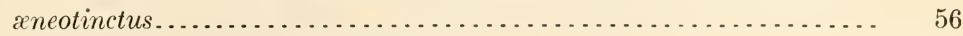

food plant of Anthonomus æneotinctus................... 39, 56

proliferation............................................. 57

weevil. (See Anthonomus æneotinctus.)

wild or bird, not food plant of Anthonomus æneotinctus............. 56

Pierce, W. Dwight, paper, "Notes on the Biology of Certain Weevils Related to

the Cotton Boll Weevil ".................................. 39-44

Plowing out in control of boll weevil................................ 7

Plum, wild, food plant of Anthonomus scutellaris..................... 40

Polygonum pennsylvanicum, food plant of Lixus musculus............... $\quad 43$

Potato beetle. (See Leptinotarsa decemlineata.)

Pratt, F. C., paper, "Notes on the Pepper Weevil (Anthonomus æneotinctus

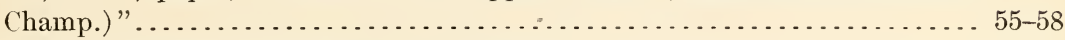

Rainfall as affecting hibernation of boll weevil . . . . . . . . . . . . . 5-6, 13

Redbud, food plant of Anthonomus signatus........................ $\quad 39$

Sanderson, E. Dwight, paper, "Hibernation and Development of the Cotton

Boll Weevil" ........................................... 1-38

Sharpshooter. (See Homalodisca triquetra.)

Sideranthus rubiginosus, food plant of Desmoris scapalis.................. 40

Sinea diadema, food............................................ 51,52

Solanum rostratum, food plant of Anthonomus æneolus................... 40

Solenopsis geminata, enemy of Anthonomus xneotinctus................ 56

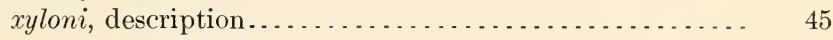

distribution........................... 48

enemy of boll weevil.................... . . 45-48

cotton leaf-worm and bollworm ........ 46

Stalk-borer, cotton. (See Ataxia crypta.)

Strawberry, food plant of Anthonomus signatus.................... . 39, 60

varieties grown in South-Central States................. 62

weevil. (See Anthonomus signatus.)

Temperature as affecting hibernation of boll weevil................. $3-6,13$

time of emergence of boll weevil from hibernation. . 19-20

Tetrastichus sp., parasite of Orthoris crotchii........................ 44

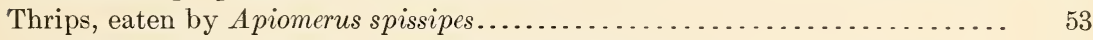

Triphleps insidiosus, eaten by A piomerus spissipes.................... 53

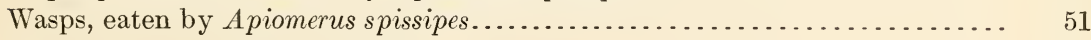

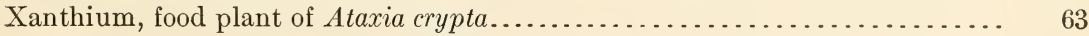







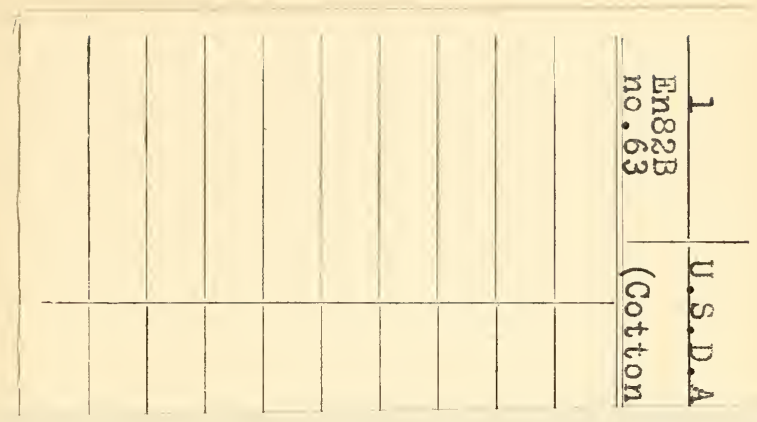

A. iomology and Plant Que...... 


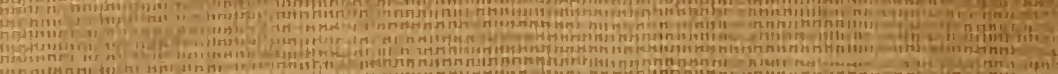

